\title{
A Middle-Late Devonian fish fauna from the Sierra de Perijá, western Venezuela, South America
}

\author{
Gavin C. Young ${ }^{1}$ \& John M. Moody ${ }^{2}$
}

With 18 figures and 1 appendix

\begin{abstract}
A new Devonian fossil fish fauna from the region of Caño Colorado between the Rio Palmar and Rio Socuy, Sierra de Perijá, Venezuela, comes from two localities and several horizons within the Campo Chico Formation, dated on plants and spores as Givetian-Frasnian in age. Placoderms are most common, with the antiarch Bothriolepis perija $\mathrm{n}$. sp., showing affinity with species from the Aztec fish fauna of Victoria Land, Antarctica. A second antiarch, Venezuelepis mingui n.g. n.sp., is also closely related to an Antarctic species, which is reassigned to this new genus. Fragmentary remains of a phyllolepid placoderm show similarity to the genus Austrophyllolepis from southeastern Australia. Chondrichthyan spines are provisionally referred to the Antarctilamnidae, and acanthodian remains include spines of the widespread taxon Machaeracanthus. Osteichthyans are represented by osteolepid and dipnoan scales and teeth, and scales lacking cosmine which may belong to another major taxon. This fauna has provided the first Devonian record from South America of three major fish groups: antiarch and phyllolepid placoderms, and dipnoans. These are widely distributed on most other continents. Although invertebrates and plants from the same sequence closely resemble those of eastern North America, the endemic elements in the fish fauna indicate Gondwana affinities. Phyllolepid placoderms are common in Givetian-Frasnian strata of Australia and Antarctica, but are only known from the Famennian in the Northern Hemisphere. The new phyllolepid occurrence extends their range across the northern margin of Palaeozoic Gondwana. The age and affinities of this new fish fauna are consistent with a model of biotic dispersal between Gondwana and Euramerica at or near the Frasnian-Famennian boundary. A narrow marine barrier separating northern and southern continental landmasses is indicated, in contrast to the wide equatorial ocean for the Late Devonian postulated from palaeomagnetic data.
\end{abstract}

Key words: Fishes, Placodermi, Chondrichthyes, Osteichthyes, Acanthodii, Devonian, Venezuela.

\section{Zusammenfassung}

Es wird eine neue devonische Fischfauna aus dem Gebiet zwischen Caño Colorado und Rio Socuy, Sierra de Perijá, beschrieben. Die Funde stammen aus zwei Lokalitäten und mehreren Horizonten innerhalb der Campo Chico Formation, die auf Grundlage von Untersuchungen der Pflanzen- und Sporenfunde dem Zeitabschnitt Givetium-Frasnium zugeordnet werden. Placodermen sind durch den Antiarchen Bothriolepis perija n. sp. häufig vertreten. Sie sind mit Arten der Aztec-Fischfauna von Viktoria Land, Antarktis, verwandt. Ein zweiter Antiarche, der Venezuelepis mingui n. g. n. sp. ist eng mit einer Spezies aus der Antarktis verwandt, die ebenfalls dieser neuen Gattung zugeschrieben wird. Fragmentarische Reste eines phyllolepiden Placodermen weisen Ähnlichkeiten mit der Gattung Austrophyllolepis aus dem Südosten Australiens auf. Wirbel eines Chondrichthyer werden vorläufig den Antarctilamnidae zugeschrieben. Acanthodir-Reste schließen das weitverbreitete Taxon Machaeracanthus ein. Osteichthyer sind durch Schuppen und Zähne osteolepider Sarcopterygier und Dipnoi vertreten. Andere Schuppen, denen die Cosminschicht fehlt, gehören vermutlich zu einem anderen Haupttaxon. Damit ist durch diese Fauna der erste Nachweis für das Vorkommen der drei Hauptfischgruppen Antiarchi, phyllolepide Placodermi und Dipnoi im Devon Südamerikas erbracht. Sie sind auch auf den meisten anderen Kontinenten weit verbreitet. Obwohl Invertebraten und Pflanzen aus derselben Zeit sehr denen aus dem Osten Nordamerikas ähneln, weisen die endemischen Elemente in der Fischfauna auf eine Affinität zu Gondwana hin. Phyllolepide Placodermen sind im Givetium-Frasnianium Australiens verbreitet, aber erst aus dem Famennium in der Nordhemisphere bekannt. Das Auftreten eines neuen Phyllolepiden weitet den Vorkommensbereich über die nördliche Linie des paläozoischen Gondwanas hinaus aus. Alter und Verwandtschaftsbeziehungen dieser neuen Fischfauna stimmen mit dem Modell der biotischen Verbreitung zwischen Gondwana und Euramerika an bzw. nah an der Frasnium-Famennium-Grenze überein. Es gibt Hinweise für eine die nördlichen und südlichen Landmassen trennende schmale Meerenge. Dies steht im Gegensatz zur Annahme eines weiten äquatorialen Ozeans im späten Devons, die sich auf palaeomagnetische Daten stützt.

Schlüsselwörter: Fische, Placodermi, Chondrichthyes, Osteichthyes, Acanthodii, Devon, Venezuela.

\footnotetext{
1 Department of Geology, Australian National University, Canberra ACT 0200, Australia.

2 Museo de Biología, Universidad del Zulia, Apartado 526, Maracaibo, 4011, Venezuela; current address, 1020, W. Morton, Denison, Texas, U.S.A.

Received October 2001, accepted April 2002
} 


\section{Resumen}

La nueva fauna de peces fósiles del Devónico de la región de Caño Colorado, entre los Ríos Palmar y Socuy, en la Sierra de Perijá, Venezuela, procede de dos localidades y varios horizontes dentro de la Formación Campo Chico, los cuales se asignan a edades del Givetiano al Frasniano. Los placodermos son los más comunes, con el antiárquido Bothriolepis perija $\mathrm{n}$. sp., el cual muestra afinidades con especies de la fauna de peces denominada "Aztec", de Victoria Land, en la Antártida. Un segundo antiárquido, Venezuelepis mingui n. g., n. sp., también tiene relaciones estrechas con una especie de la Antártida, la cual es aquí reubicada dentro de este nuevo género. Los restos fragmentarios de un placodermo filolépido muestran similitudes con el género Austrophyllolepis, procedente del sureste australiano. Las espinas de condrictios se identifican provisionalmente como Antarctilamnidae, y los restos de acantódidos incluyen espinas de Machaeracanthus, un taxón de amplia distribución. Los osteictios están representados por escamas y dientes de osteolépidos y dipnoos; y otras escamas que carecen de cosmina podrían pertenecer a un taxón adicional predominante. Esta fauna ha suministrado el primer registro de tres grupos principales de peces en el Devónico suramericano: los placodermos antiárquidos y filolépidos, y los dipnoos. Estos grupos tuvieron amplia distribución en la mayoría de los continentes. Mientras los invertebrados y plantas de la misma secuencia se parecen mucho a los del oriente norteamericano, los elementos endémicos de la ictiofauna indican afinidades con Gondwana. Los placodermos filolépidos son comunes en los estratos del Givetiano-Frasniano de Australia y la Antártida, pero solo se les conoce del Fameniano en el hemisferio norte. La presencia de filolépidos aquí detectada, extiende su distribución a través del margen norte de la Gondwana paleozoica. Tanto la edad como las afinidades de esta nueva fauna de peces son consistentes con un modelo de dispersión biótica entre Gondwana y Euramérica, en o cerca de, el límite Frasniano-Fameniano. Se indica una barrera marina angosta que separa las masas continentales austral y boreal, en contraste con un océano ecuatorial ancho, postulado mediante información paleomagnética, para el Devónico Tardío.

Palabras clave: Peces, Placodermi, Chondrichthyes, Osteichthyes, Acanthodii, Devónico, Venezuela.

\section{Introduction}

Fossil fish remains were first discovered in the Campo Chico Formation during fieldwork in 1990 in the Sierra de Perijá, western Venezuela, to collect Devonian plant remains from new rock exposures resulting from road construction. Benedetto (1984) had earlier described Devonian brachiopod assemblages along the "Route au Rio Socuy" in the vicinity of Caño Colorado (Fig. 1), and Edwards \& Benedetto (1985) reported the first Devonian plant remains from two localities along this road. Erosion of the old road, and construction of a new road downslope to the west, provided extensive new exposures from which a significant Devonian flora has now been documented (Berry et al. 1993, Berry 1994, 2000, Berry \& Edwards 1994-97, Berry \& Stein 2000).

In early 1990 a shark fin-spine impression was discovered in the new road exposure during a collecting expedition for fossil plants (C. Berry, J. Casas, J.M.M.). A report of this investigation (Casas et al. 1990), and photographs of the spine, were sent to G.C.Y. for identification. Subsequent correspondence noted a nearby locality (Caño Colorado Sur), recorded by Benedetto (1980a: 831, 834) to have yielded bone fragments of Mississippian labyrinthodont amphibians. J.M.M. visited Caracas to examine these samples, but they could not be found, so a field trip was arranged, and the fossil site was relocated (J.M.M. and Alfredo Perez, 18 April, 1991). Amongst the collected material was a specimen which could be compared with a published illus- tration (Young 1989: fig. 4B) of the antiarch placoderm Bothriolepis askinae described from the Devonian Aztec Siltstone of southern Victoria Land, Antarctica (Young 1988a). From that comparison J.M.M. identified a left lateral bone from the skull of Bothriolepis (the specimen figured by Young et al. $2000 \mathrm{~b}$ : fig. $2 \mathrm{~A}$ ). This was the first confirmed occurrence in South America of a major placoderm group, the order Antiarchi. At that time, this group had been recorded from Devonian strata in all other regions of the world except Africa and South America, with the genus Bothriolepis, the most widespread known Devonian fish, known by over 70 species worldwide, from hundreds of localities distributed from $76^{\circ} 50^{\prime} \mathrm{N}$ latitude (Ellesmere Island) to $79^{\circ} 30^{\prime} \mathrm{S}$ (Victoria Land, Antarctica).

This significant discovery also demonstrated that the fossil assemblage must be of Devonian age, rather than Carboniferous as earlier assumed. Further collecting was justified, and arrangements were made for another expedition to the new locality at Caño Colorado Sur. A considerable collection was excavated from this locality, and further fish material was also collected from the Rio Socuy Road section, during the period 4-13 July 1992 (G.C.Y., J.M.M., J.E. Casas, staff and students from the University of Zulia, Maracaibo). Construction of a new reservoir on the Rio Palmar, which was likely to result in the flooding of this locality, added some urgency to the collecting expedition (although the project was later delayed, and dam construction is still not complete). Some additional fish specimens have been found since 1992, supple- 
menting the original collection which forms the basis for the descriptions presented here.

Since our original discovery, the genus $\mathrm{Bo}$ thriolepis has now been described also from South Africa by Long et al. (1997), and recently from Colombia by Janvier \& Villarroel (2000). In addition, our new fauna includes several other groups not previously known from South America (e.g., phyllolepid placoderms), or representing the oldest known occurrence in South America (e.g., Dipnoi, the lungfishes). The new Venezuelan fish assemblage contains predominantly placoderm remains, and thus is rather different from the chondrichthyan-acanthodian dominated Devonian vertebrate assemblages reported from Bolivia and Brazil in recent decades (e.g., Goujet et al. 1984, Janvier 1976, 1987, Janvier \& Dingerkus 1991, Janvier \& Melo 1987-1992, Maisey 2001). Placoderms have otherwise been definitely recorded from South America only by Goujet et al. (1984, 1985, 1993) and Diaz-Martínez et al. (1996). Two earlier references to Devonian fish remains from Venezuela are Bowen's (1972) "fish teeth" from lower in the Devonian sequence of the Sierra de Perijá (see below), and indeterminate fish scales of supposed Middle Devonian age reported from a borehole in the Maturin Basin by Thery (1982). There was also an early illustration of supposed antiarch remains from Argentina by Frenguelli (1952: pl. 1: 2), considered unreliable by Young (1984a: 444). Although refigured by Janvier \& Suarez-Riglos (1986: fig. 1), this record remains extremely doubtful until substantiated by new material.

As recently discussed (Young et al. 2000b), the fact that this locality was apparently located on the northwestern margin of Palaeozoic Gondwana, and shows a distinct "Gondwana" element in the fish fauna, has implications for Devonian palaeogeographic reconstructions. The full significance of this locality depends on a detailed systematic description of the fauna, which is presented in this paper.

\section{Material and methods}

Most blocks from Caño Colorado Sur contain many jumbled plates, and it was not practicable to fully prepare all specimens. After field examination, the entire collection was surveyed on return to Maracaibo in 1992, and more promising specimens visible on the surface were selected for preparation. Bone margins were exposed by mechanical means, and some were cleaned using weak acid to remove the bone, before casting with latex rubber. Latex casts were whitened with ammonium chloride before photography; some specimens of darker bone with clear outlines were photographed in the rock. Limited resources and facilities meant that much of the collection remains unprepared. The systematic study presented here is based on only a small proportion of the total available material, but we consider general faunal content to be correctly documented for the upper Campo Chico Formation (Caño Colorado Sur locality). New information on poorly known taxa should be forthcoming if the remaining material is prepared (e.g., skull remains of the osteolepid, so far known only from scales and a few teeth).

The material from the Rio Socuy Road section was much more scattered, and largely derived from float, with the fossiliferous beds mainly inaccessible. The faunal list for the lower Campo Chico Formation may therefore be incomplete.

The bulk of the Venezuelan collection is retained in Maracaibo (Museo de Biologia, Universidad del Zulia). Most of the cast material is also represented by permanent replicas in the Museum für Naturkunde, Berlin (numbers listed in the Appendix).

\section{Abbreviations}

Specimen number prefixes used below refer to collections in the following institutions:

CPC: Commonwealth Palaeontological Collection (held in Geology Dept., Australian National University, Canberra)

MB.f.: $\quad$ Museum für Naturkunde, Institut für Paläontologie, Berlin

MBLUZ P-: Museo de Biología, La Universidad del Zulia, Maracaibo, Venezuela

NMV: National Museum of Victoria, Melbourne

WAM: Western Australian Museum, Perth

Standard abbreviations for placoderm dermal bones are used in the text and figures, as listed here: a1SM, anterior attachment area for SM plate; ad1,2, anterior and posterior articular processes on SM; ADL, anterior dorsolateral plate; AMD, anterior median dorsal plate; arv, ventral articular area of pectoral fin; AVL, anterior ventrolateral plate; a.un, unornamented area beneath pectoral fossa; c.al, anterolateral corner of ventral lamina of AVL; Cd1,2, first and second dorsal central plates of pectoral fin; cfADL, MxL, contact face for overlapping $\mathrm{ADL}, \mathrm{MxL}$; cir, semicircular pitline groove; cpm1, anterior postmarginal corner of La plate; cr.pl, postlevator crista of AMD; crtp, posterior internal transverse thickening; csl, central sensory line groove; Cv1, first ventral central plate of pectoral fin; d.end, endolymphatic duct opening; dlg1,2, anterior and posterior oblique pitline grooves; dma, tergal angle of AMD and trunk armour; dmr, dorsal median ridge; eth.c, ethmoid commissure; gr, groove; grm, ventral median groove; ifc, infraorbital sensory groove; ifc1,2, branches of ifc on La plate; IG, infragnathal bone; ins, insertion 

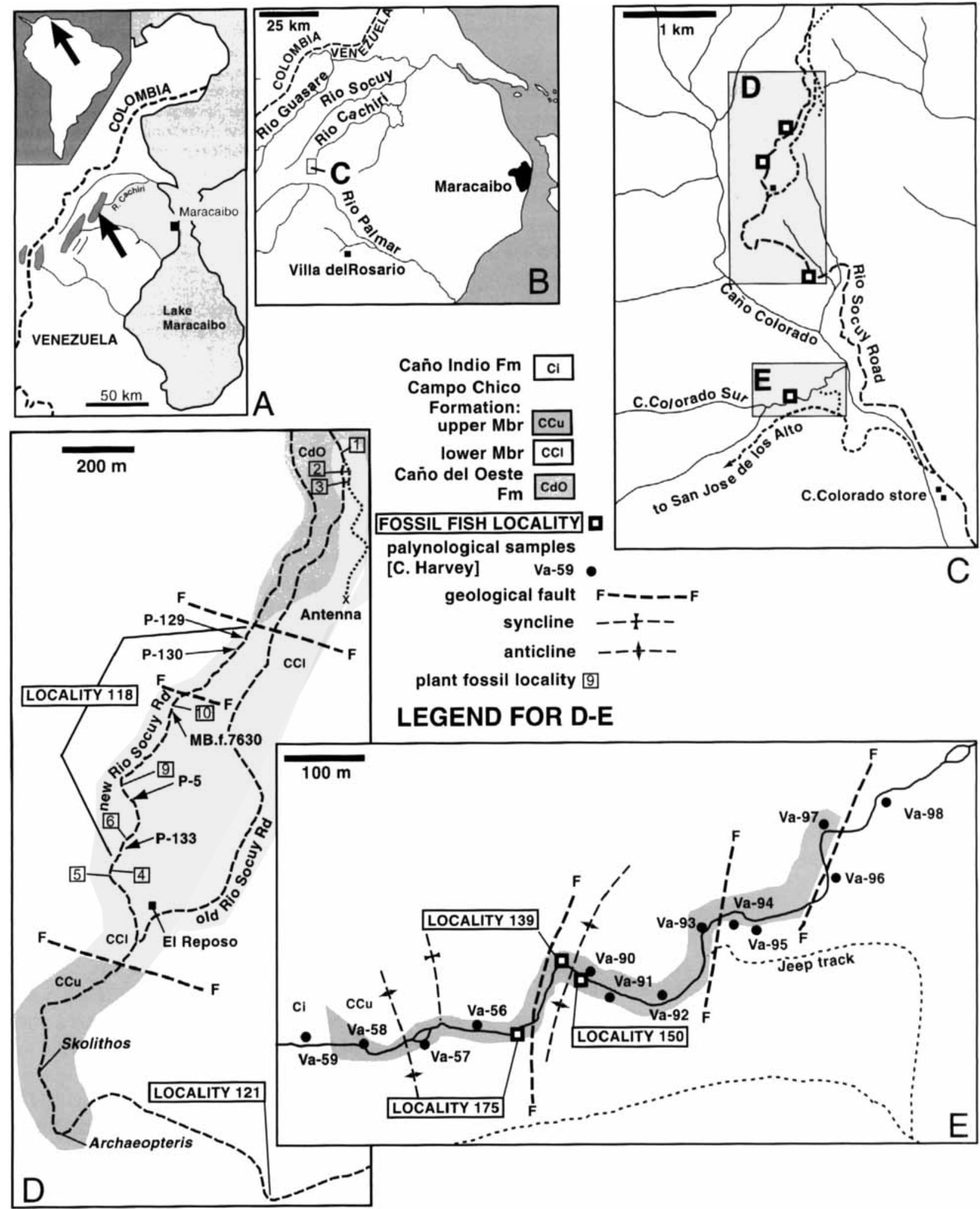

Fig. 1. Locality map. A. Region of the Sierra de Perijá, western Venezuela, showing general areas of Devonian outcrop, and the location of the new fossil fish localities at the headwaters of the Rio Cachiri and Rio Palmar (arrow). B. Location of the Caño Colorado - Rio Socuy Road area shown in C. C. The two main fossil fish localities in the Caño Colorado area. D. Detailed map of fossil localities in the new roadcut section, Rio Socuy Road. E. Detailed map of fossil localities in the Caño Colorado Sur section. C, D based on a GPS survey by C. Berry and J. Moody, February, 2001, UTM GPS grid SAm 69 datum. Geological structures after Casas et al. $(1990,1992)$. 
area of fin spine; $\mathbf{L 1 , 2}, \ldots$, first and subsequently added lateral ornamental ridges of fin spine; La, lateral plate; lam, lateral spine row of pectoral fin; lc, lateral corner of AMD, MV; lcg, main lateral line sensory groove; $\mathbf{M}$, median ornamental ridge of fin spine; $\mathbf{M 1 2}$, lateral marginal plate 2 of pectoral fin; MV, median ventral plate; mvr, median ventral ridge; MxL, mixilateral plate; n.Cd2, notch for $\mathrm{Cd} 2$ plate; $\mathbf{n m}$, obtected nuchal area; pl, postlevator notch; nPP, notch for PP plate; nprl, prelateral notch of skullroof; $\mathbf{N u}$, nuchal plate; oaMxL, PDL, PMD, areas overlapped by MxL, PDL, PMD; orb, orbital margin; PDL, posterior dorsolateral plate; p.emb, pectoral embayment; PM, postmarginal plate; PMD, posterior median dorsal plate; $\mathbf{P N u}$, paranuchal plate; PP, postpineal plate; prc, prepectoral corner of AVL; PrL, prelateral plate; PrM, premedian plate; pror, preorbital recess of skull; prpl, external postlevator process of AMD; pt1,2, anterior and posterior ventral pits of dorsal trunk armour; PVL, posterior ventrolateral plate; SI, semilunar plate; SM, submarginal plate; sna, supranuchal area; SO, suborbital plate; soc, supraorbital sensory groove; tub, tubercle.

\section{Stratigraphic setting}

The Sierra de Perijá rises to $3688 \mathrm{~m}$ (Monte Plano), as a northward extension of the Andes along the Venezuelan-Colombian border. Large tracts of undifferentiated Palaeozoic strata have been represented on geological maps of this region (e.g., Gonzalez et al. 1980: fig. III-8), including the area between Caño Colorado and Rio Socuy, about $70 \mathrm{~km}$ west of Maracaibo (Fig. 1A, B). The Devonian of this area was mapped by Bowen (1972: fig. 4) as the Cachiri Anticline, with an outcrop tract some $20 \mathrm{~km}$ long. Marine invertebrate fossils of Devonian age were discovered here many years ago (Weisbord 1926, Liddle et al. 1943). Subsequent work on the Devonian stratigraphy of the area (Sutton 1946, Bowen 1972) identified three fossiliferous formations within the Rio Cachiri Group (Fig. 2A), from the base to the top the Caño Grande, Caño del Oeste, and Campo Chico Formations. The first two formations are of Early and Middle Devonian age respectively, based on extensive marine invertebrate assemblages, particularly from the Caño del Oeste Formation (e.g., Benedetto 1979, 1984, de Carvalho \& Moody 2000). The overlying plant-bearing sequence (Campo Chico Formation), which has yielded the fish fauna de- scribed below, is best known from two main localities (Caño Colorado Sur, Rio Socuy Road; Fig. 1C). The first reference to Devonian fish remains in this area was by Bowen (1972: 740), who noted "dientes de peces indeterminados" in the underlying Caño Grande Formation. Odreman \& Medina (1984) considered this to be a misidentification, but their reasons are no longer valid, and fish remains have recently been recorded from strata of similar age in Colombia (Janvier \& Villarroel 2000). Unfortunately the locality and sample details for this Caño Grande Formation material are not known, but according to Myles Bowen (in litt. 28 May, 1995), "the fossil collections were sent to Scrutton in England, who got everything identifiable identified". Scrutton (1973) reported on Devonian and Carboniferous corals from the Sierra de Perijá.

The two collecting areas for the fish fauna described below are up to $3 \mathrm{~km}$ apart (Fig. 1C), and separated by at least $200 \mathrm{~m}$ of section, but correlation between the two areas is not straightforward. The Rio Socuy Road section includes a lower contact with the underlying Caño del Oeste Formation, but the section is faulted (Fig. 2), so thickness is uncertain. Brachiopod faunas lie some $50 \mathrm{~m}$ below the lowest rich plant horizons (Berry et al. 1993: 37). The Caño Colorado Sur locality is again faulted and folded, and a contact with the overlying Caño Indio Formation (Pennsylvanian; Benedetto 1980a) occurs some $300 \mathrm{~m}$ upstream from the main fish beds (Fig. 1E). This upper part of the Campo Chico was first called the "Formación Caño del Noroeste" by Bowen (1972). After new field investigations, Benedetto (1980b), reinterpreted this as a single "continental" plant-bearing deposit (the Campo Chico Formation, with upper and lower members), lying between the marine Caño del Oeste Formation (Givetian) and Caño Indio Formation (Pennsylvanian).

Correlation between the two fish-bearing sections is based in part on recognition of a Skolithos horizon above the fish horizons in the section at Caño Colorado Sur. This was first recorded by Benedetto (1980b), who also noted Conchostraca ("Estheria") in associated beds. (The latter occurrence was overlooked by Tasch (1987), whose oldest South American conchostracans were Permian, with only Mesozoic forms recorded from Venezuela.) Horizons with Skolithos were relocated in sections measured in the 1995 and 1998 field seasons (J.M.M., C. Berry, C. Harvey), at 12 and $17 \mathrm{~m}$ above the base of the section (Fig. 2C). Another Skolithos zone occurs in the road cut sec- 


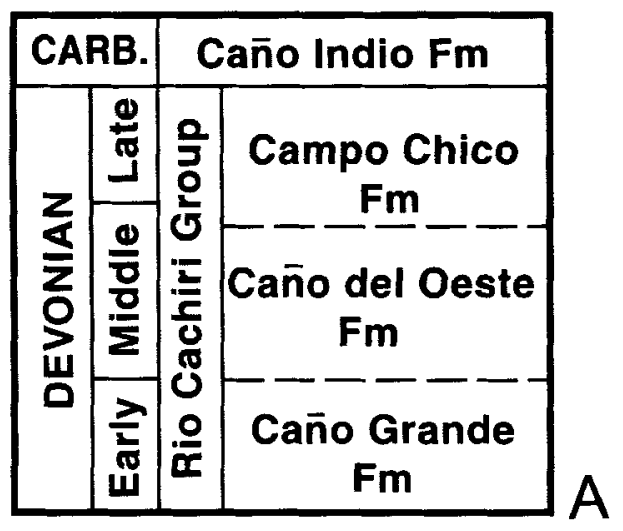

$15 \mathrm{~m}$

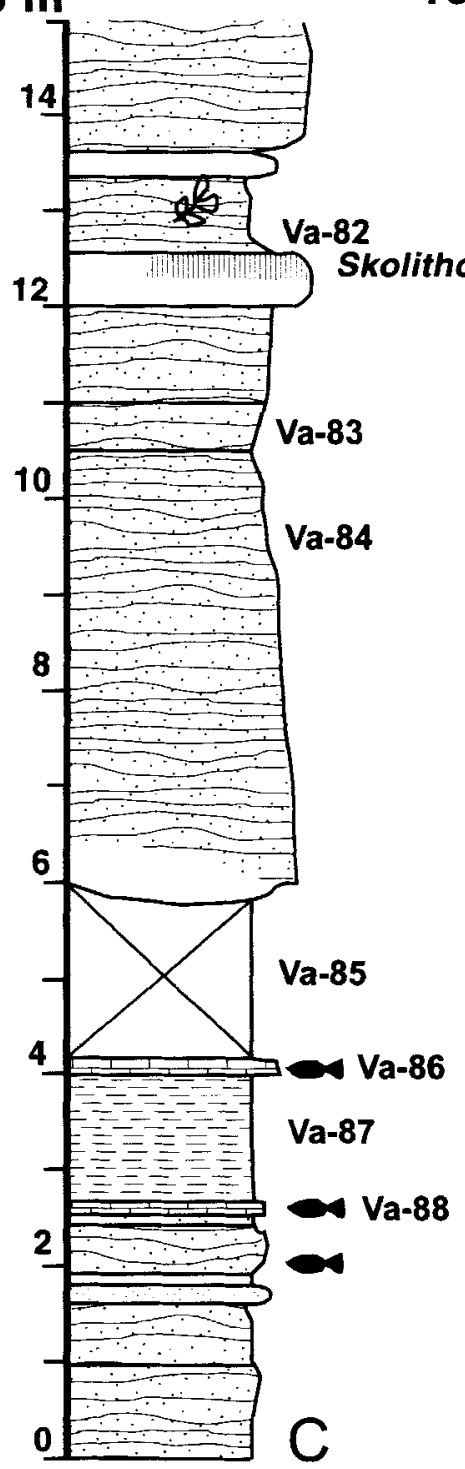

$15 \mathrm{~m}$

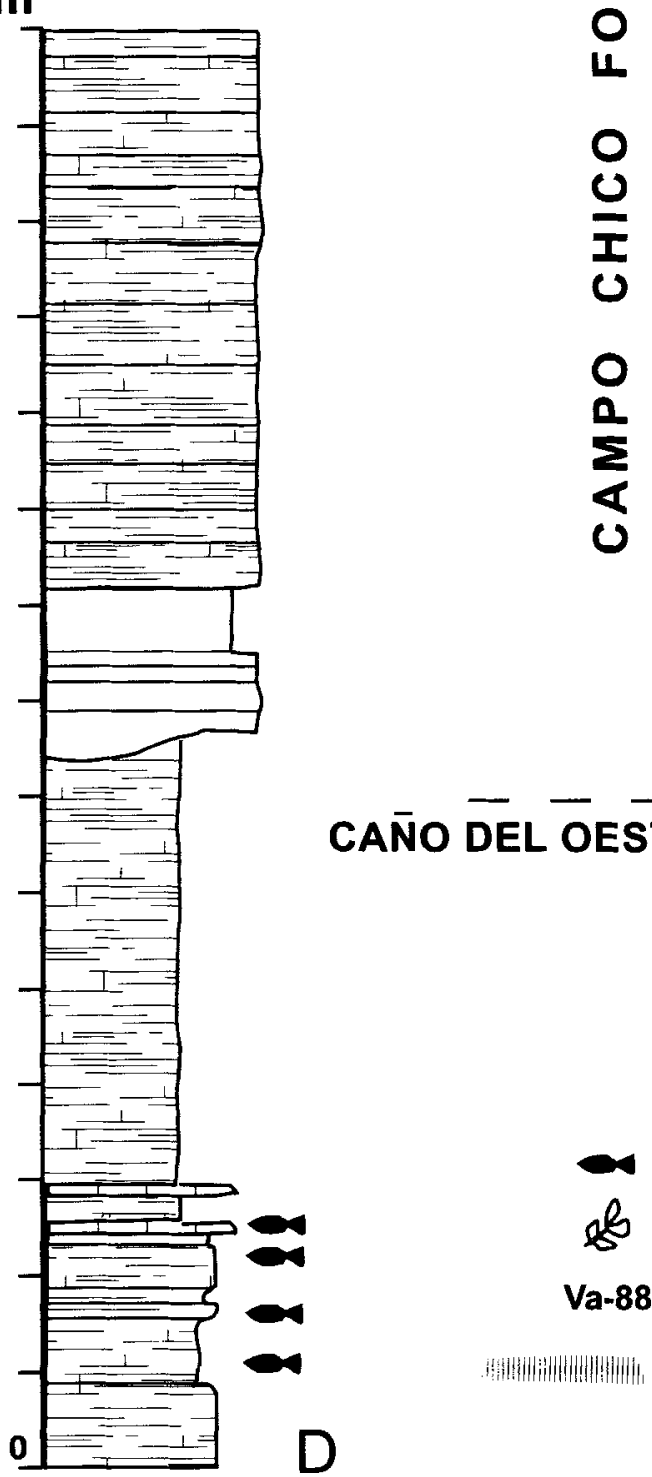

New Road, S. of El Reposo

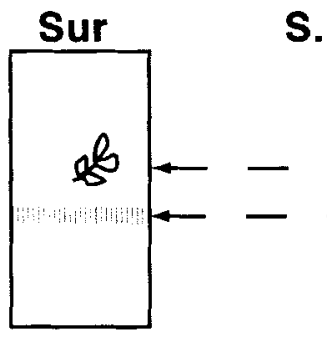

$\rightarrow$ Skolithos

\section{UPPER MEMBER}
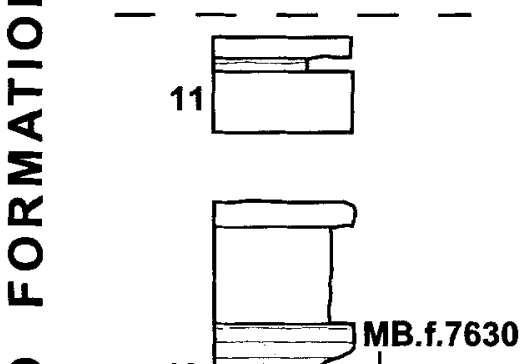

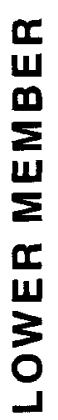

10
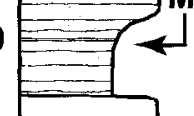

9
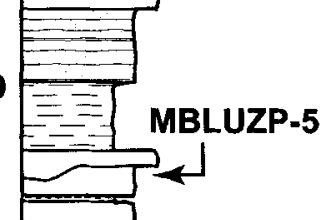

3

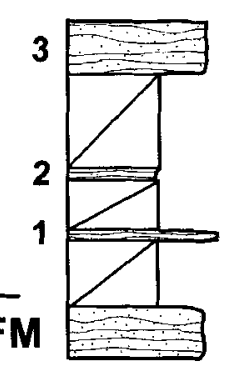

New/Old Road

sections

(Berry et. al. 93)

B

KEY

\section{fish horizon}

macroplant horizon

palynological sample

Skolithos horizon

Fig. 2. A. General stratigraphic scheme for the Devonian sequence in the Caño Colorado - Rio Socuy Road area. B. Composite New/Old Road sections through the Lower Member of the Campo Chico Formation (from Berry et al. 1993: fig. 2), with suggested correlation between the Upper Member in the new road section south of El Reposo, and the section at Caño Colorado Sur (based on Skolithos and Archaeopteris horizons). C. Caño Colorado Sur section of C. Harvey (2001), showing fish and palynology sampling horizons. D. Caño Colorado Sur lithological measured section as originally presented by Casas et al. (1992: fig. 7). 
tion south of El Reposo hacienda, and south of a fault (Fig. 1D). This lies about $20 \mathrm{~m}$ stratigraphically beneath a plant horizon containing Archaeopteris, in what is assumed to be the upper member of the Campo Chico Formation (C. M. Berry, pers. comm.; Berry et al. 2000: 265). Earlier, Benedetto (1980b: 834, fig. 2) had also recorded a plant horizon with "lepidodenrales" from above the Skolithos horizon in the section at Caño Colorado Sur. Because of its position in relation to Skolithos, this plant bed has been assumed to be equivalent to the Archaeopteris horizon in the Rio Socuy Road section (Fig. 2B), although only badly preserved indeterminate lycopsids have been found (C. Berry, pers. comm. (email) 18 Nov. 2000).

It is noted here that the Skolithos zone above the main Caño Colorado Sur fish horizon is a double bed, and the beds are much thinner than the Skolithos zone in the road cut section. There are also some differences in the miospore assemblages at the two localities (Harvey 2001). This correlation is therefore probably only an approximate alignment of sections exhibiting similar facies development, with the Skolithos beds assumed to be confined to a narrow stratigraphic interval. On this basis the sections with Skolithos have been assumed to represent the $u$ pper member of the Campo Chico at both localities (Fig. 2B). Thus, the new fish fauna described here apparently comprises two assemblages, one in the upper and one in the lower member of the Campo Chico Formation, which are separated in the section by an unknown thickness of sediment. It is noteworthy that no taxa so far identified are common to both localities and horizons. Taken together the total fauna comprises at least 9-10 taxa, of which four are placoderms (one in the lower and three in the upper member), two or three are osteichthyans (all in the upper member), and there is probably one chondrichthyan and two acanthodians in the lower member. Acanthodians are also represented by some scales in the upper member.

\section{Fossil Localities}

Details of all collecting localities yielding fish are given below, and shown as numbers on Figure $1 \mathrm{D}, \mathrm{E}$. A superceded field numbering system is given in parentheses (some earlier samples may carry these numbers). Plant locality numbers used by Berry et al. (1993) are also indicated in Figs $1-2$.

\section{Rio Socuy Road, new roadcut section (Fig. 1D)}

A. Locality 118 (old L-9-VEN). This is the main road cutting along the new section of road, measured as extending from 5.5 to $6.5 \mathrm{~km}$ up the road from the road junction near the Caño Colorado crossing and just north of the store (Fig. 1C). It includes plant fossil localities 4-10 of Berry et al. (1993; horizons A-G of Casas et al. 1990). Fish fossil samples (mainly fin spine impressions) came from a one $\mathrm{km}$ long section of road; they apparently derive from a number of specific beds, but nearly all were found as loose blocks. These beds are all considered to belong to the lower member of the Campo Chico Formation. One large sandstone block found in 1994 as float near the centre curve of the road cut section (MBLUZ P-1346) had fallen from the cut above after local rains. The size of this large block (which had to be broken to lift it into the jeep) suggested derivation from a specific sandstone bed high up on the wall of the roadcut (only accessible from above using mountain climbing equipment). This bed may be the source for much of the float material collected in this area, including all the spines assigned to the acanthodian Machaeracanthus (known only from float). The only specimens collected in situ are the first two spines found (MBLUZ P-5, MB. f.7630), which are separated by some $50 \mathrm{~m}$ of section (between plant localities 8 and 10 of Berry et al. 1993: fig. 2c). Their stratigraphic position is indicated in Figure 2B. The two phyllolepid placoderm impressions (MBLUZ P-129, 130) were found as float at the upper end of the roadcut section (collection sites indicated by specimen numbers in Fig. 1D). This is within the faulted block with almost horizontal bedding identified by Berry et al. (1993: figs 3a,b) to lie north of plant locality 10 , which at the top of the road section is juxtaposed against the underlying Cano del Oeste Formation (contact represented by $30 \mathrm{~m}$ of non-exposure). Berry et al. (1993: 35) assume these subhorizontal strata to be "high in the Campo Chico Formation", based on missing beds and plant intervals along the old road indicating some $150 \mathrm{~m}$ minimum displacement along the main fault.

B. Locality 121 (old L-12-VEN). These low cuttings are further down the road (odometer reading $4.0 \mathrm{~km}$ up from the road junction just 
north of the Caño Colorado store), and have produced only a few fossil samples as float (shark spine MBLUZ P-134; probable $\mathrm{Ma}$ chaeracanthus spines also observed in a large float block that could not be collected). They have a similar sandstone lithology to material from the previous locality, and are assumed to also come from the lower member of the Campo Chico Formation. It is not clear whether there is a continuous sequence or faulted contact with the fossil occurrences in the upper member, about $0.5 \mathrm{~km}$ up the road (locality 138, old L-23-VEN), which include Skolithos horizons and the Archaeopteris plant locality (Fig. 1D). The two localities are separated by a wide covered section of no outcrop.

\section{Caño Colorado Sur (Fig. 1E)}

A. Locality 139 (old L-24-VEN). This is the main fish collecting locality from Caño Colorado Sur, situated about $3 \mathrm{~km} \mathrm{~S}$ of the roadcut section (Fig. 1C, E), and assumed to represent the upper member of the Campo Chico Formation (Fig. 2). Fish remains came from four beds in the lower part of a $15 \mathrm{~m}$ section (Fig. 2C, D).

B. Locality 150 (old L-27-VEN). This locality is about $25 \mathrm{~m}$ E of the previous locality, on the eastern flank of an anticline, and apparently from a similar horizon. However the only identified specimen (MBLUZ P-1387) is a possible ptyctodontid placoderm plate, a taxon not found at locality 139 , so this approximate correlation remains uncertain.

C. Locality 175 (old L-50-VEN). This is about $150 \mathrm{~m}$ upstream from the main fish collecting locality at Locality 139 (Caño Colorado Sur). During section measuring in 1995 a few plant and fish fragments were found in the interval with three thin Skolithos horizons (12-17.5 m above the base in logged sections of Harvey 2001). Sample MBLUZ P-1392 (an undetermined thick bone fragment) came from this locality (see Appendix).

\section{Depositional environment}

A "restricted water" environment for the Campo Chico Formation was suggested by Bowen (1972), and Benedetto (1980b) regarded it as a "continental" plant-bearing deposit. Berry et al. (1993) noted interbedding of sediments contain- ing plant remains and those with marine fossils at the (transitional) lower boundary of the Campo Chico Formation. Within its lower part, one of the lower horizons in the new road section (their locality 4) is apparently marine (an organic rich shale with scolecodonts), and this is overlain by a series of cross-bedded sandstones indicating alluvial deposition, with several plantrich horizons (localities 5-8). Overlying dark shales and coal horizons were interpreted as shallowing of a lacustrine or lagoonal situation and development of swampy conditions. Above this, about $50 \mathrm{~m}$ above the base of the section, an articulated crinoid was found, which demonstrates a marine influence in several cycles of sandstone/shale deposition possibly indicating fluctuating sea-level. Recent palynological sampling by Harvey (1999, in prep.), has indicated at least six marine-influenced phases in the Rio Socuy Road section, which are represented by low diversity, acritarch-bearing horizons (pers. comm. $8 / 6 / 01)$.

The shark spines described below all come from the Rio Socuy Road section, as do the $\mathrm{Ma}$ chaeracanthus spines. The shark spines are compared with Antarctilamna, which Young (1982) considered to be a "fresh-water" chondrichthyan. They also resemble "Ctenacanthus" spines, and Maisey (1981, 1984: 16) considered all valid species of Ctenacanthus to come from marine deposits. The acanthodian genus Machaeracanthus is widely reported on the basis of scales and spines from a variety of assemblages, including some associated with marine invertebrates, and the trace fossil Skolithos has been interpreted as indicating shallow marine conditions (e.g., Seilacher 1967, 1978, Frey 1978, Bjerstedt 1987). On the other hand, the only placoderm found at this locality is a phyllolepid, a group considered to be confined by marine barriers because of its peculiar disjunct distribution, both geographically and stratigraphically (Young 1988b, 1993b, in press, Young et al. 2000a,b). However precise horizon of the two known specimens is not established (found as float; see above).

The Caño Colorado Sur section has likewise produced evidence of marine influence in miospore assemblages (Harvey 2001). Rare spores and acritarchs were obtained from samples Va86 to 88 , and sample Va- 86 also contained chitinozoans (C. Harvey, pers. comm. 8/6/01). The thin limestone bands just above the fish producing layers have been etched for conodonts, without results so far, although a few acanthodian scales have been obtained by acid etching 
(see below). In the fish-producing layers a reducing environment is indicated by pyritic layers associated with some samples (e.g., P-152). It is clear that some of the bones were broken before deposition, and many are randomly oriented in the sediment. However the most common remains (the antiarch Bothriolepis) include some scattered remains from single individuals, with one articulated specimen (the holotype), suggesting rapid burial under quiet conditions. The dorsal bones of the trunk armour (AMD and PMD plates) may be over-represented in the material, perhaps suggesting some current sorting of isolated bones, but this needs to be confirmed by preparing many more samples.

In summary, both localities can be assumed to encompass a range of "marginal" palaeoenvironments in a coastal plain setting, including fresh or brackish water deposits at certain horizons, and others with direct connection to the open ocean. Rapid sea level fluctuations are well documented for the Middle-Late Devonian (e.g., Becker 1993), and specific environments in a marginal setting would change on a bed-by-bed basis. More detailed spore analysis in different sections may greatly improve the precision of age determinations if specific transgressive phases can be correlated. For example, the midFrasnian marine event recently identified by Higgs et al. (2000) in the Munster Basin, Ireland, could approximate to marine horizons in the Escuminac sequence of Canada, noted for its famous Devonian fish fauna (Schultze \& Cloutier 1996), but which has also produced acritarchs at some horizons (Cloutier et al. 1996). Similar comparisons might apply to the acritarch and fish horizons in the Venezuelan sequence.

A major question concerns the dispersal capabilities of fish taxa in the Venezuelan fauna, but evidence of depositional environment provides no direct data regarding the process by which these organisms attained their observed distribution patterns. As with living fish groups, this can only be inferred from an analysis of distribution pattern in relation to phylogeny (Rosen 1974). As noted above, the antiarch Bothriolepis is the most widespread Devonian fish, even though it commonly occurs in assumed non-marine assemblages (i.e. lacking marine invertebrate fossils). As well as B. canadensis from the Escuminac sequence, the genus is known from deposits with abundant marine invertebrates (e.g., the interreef Frasnian Gogo Formation of Western Australia). Its wide distribution in the Late Devonian can only be explained by marine habitat for at least some species (Young, in press), and Young et al. (2000b: 759) suggested that "Bothriolepis no doubt dispersed through the sea". However the closer affinity between Bothriolepis perija n. sp. described below and other Gondwanan species, rather than those from (geographically closer) Northern Hemisphere localities, is consistent with dispersal along coasts for this species, which did not involve crossing of marine barriers. Thus, some Bothriolepis species could still be categorised as a "continental" fishes in the sense of Rosen (1974).

\section{Age of the fish fauna}

The Campo Chico Formation has previously been assessed as of Givetian-Frasnian age, based on the age of invertebrate faunas lower in the sequence, and the general affinities of the plant assemblages (Berry et al. 1993). The same general age is indicated by the fish assemblage (Young et al. 2000b), and this can be now refined to an interval which is younger than mid-Givetian, and older than late Frasnian. Recent analysis of miospore assemblages from this sequence (Harvey 1999,2001$)$ has provided more precision for specific levels, as follows (C. Harvey, pers. comm. 8/6/01):

- The upper Caño del Oeste and lower Campo Chico Formation exposed along the old road sections (Rio Socuy Road) are tentatively assigned to the lemurata-magnificus and the optivus-triangulatus Assemblage Zones of Richardson \& McGregor (1986), equivalent to the AD Lem and TA Oppel Zones of Streel et al. (1987). These indicate an approximate mid- to late Givetian age.

- The Lower Member of the Campo Chico Formation exposed along the new road section spans the ?upper optivus-triangulatus to ovalisbulliferus Assemblage Zone of Richardson \& McGregor (1986) and questionably the TA and BJ/BM Oppel Zones of Streel et al. (1987). This indicates that these sediments are no older than late Givetian to early Frasnian in age.

- Miospores from the Upper Member of the Campo Chico Formation exposed at the $A r$ chaeopteris locality in the New Road section indicate at least a mid-Frasnian age, equated with the mid ovalis-bulliferus Assemblage Zone of Richardson \& McGregor (1986), and the IVa and IVb phase of Streel et al. (1987). This age constraint is based principally on the 
occurrence of Rugospora briceii throughout the Upper Member, in association with abundant Verrucosisporites bulliferus, Samarisporites triangulatus, Geminospora lemurata, Cymbosporites hormiscoides var. hormiscoides, Aneurospora greggsii, Spelaeotriletes boletus and $S$. tabulatus.

- Miospore assemblages from the presumed Upper Member of the Campo Chico Formation exposed in the Caño Colorado Sur section indicate an early to mid-Frasnian age, also equated with the mid ovalis-bulliferus Assemblage Zone of Richardson \& McGregor (1986) and the IVa and IVb phase (Streel et al. 1987). This age designation is similar to that ascribed to the Upper Member at the Archaeopteris locality, and reflects the similarity of dominant assemblage components.

\section{Comparisons with other fish faunas of similar age}

The closest Devonian fish fauna in terms of modern geography is that recently described from the Cuche Formation of north-eastern $\mathrm{Co}-$ lombia by Janvier \& Villarroel (2000), who assess their fauna as of probable late Frasnian age, possibly extending into the early Famennian. Elements in common with the fauna described here include Bothriolepis (possibly two species, both of which can be separated from $B$. perija n. sp. described below), and a shark spine assigned provisionally to Antarctilamna, but also of somewhat different morphology to the chondrichthyan spines described below. Acanthodian scales (Cheiracanthoides? sp. indet.) may be similar to those from the Venezuelan fauna, but could belong to a variety of acanthodian taxa. Rare cosmine-covered dermal bone and scale fragments are also recorded (Janvier \& Villarroel 2000: 748). However the following five taxa in the Colombian fauna are not represented in the Campo Chico fish fauna described below:

\section{Placoderms:}

Asterolepis? sp. indet.

Arthrodira gen. et sp. indet.

\section{Osteichthyans: \\ stegotrachelid actinopterygian, gen. et sp. indet. Holoptychius sp. indet. \\ Strepsodus? sp. indet.}

Janvier \& Villarroel (2000: 756) noted a striking resemblance to Late Devonian fish assem- blages of Europe and North America, in particular indicated by three taxa: the asterolepid antiarch Asterolepis, with no confirmed occurrences outside Euramerica; the porolepiform $\mathrm{Ho}$ loptychius, which is well documented in the Frasnian of Euramerica; and the rhizodontid genus Strepsodus, said to be unknown outside Euramerica in rocks older than latest Famennian. In East Gondwana, Holoptychius occurs only in Famennian strata (Young 1993a), but it is noted that rhizodontids definitely occur in the Aztec fish fauna (Givetian-Frasnian) of Victoria

Land, Antarctica (Young et al. 1992: figs 3940 ), and may occur in older strata in Australia (Young, unpublished). Janvier \& Villarroel (2000) identified a possible Gondwanan element in the Colombian fauna because of the antarctilamnid shark, but the Colombian rhizodontid would also indicate Gondwanan affinity, given its likely preFamennian age. It is noted that the shark spine is associated with a tooth closely resembling Portalodus from the Antarctic Aztec fauna (Janvier \& Villarroel 2000: fig. 5A; cf. Long \& Young 1995).

Other comparisons can be made with the 40 ichthyofaunas of late Givetian-early Frasnian age analysed by Schultze \& Cloutier (1996). A summary of the distribution of 8 major taxa (mainly families) in the Venezuelan fauna across their 40 localities is given in Table 1.

Table 1

Summary of distribution of the 8 groups represented in the Venezuelan fish fauna, across the 40 localities discussed by Schultze \& Cloutier (1996). "Ctenacanthidae" includes Antarctilamnidae. "Dipteridae" is assumed to contain the only dipnoan in the fauna. Taxa in common with the Venezuelan fauna are summed in the bottom row.

\begin{tabular}{|c|c|}
\hline Locality & $\begin{array}{cccr}1 & 2 & 3 & 4 \\
1234567890123456789012345678901234567890\end{array}$ \\
\hline $\begin{array}{l}\text { Ptycto- } \\
\text { dontidae }\end{array}$ & 0100000000000111101111001100000100010011 \\
\hline $\begin{array}{l}\text { Phyllo- } \\
\text { lepidae }\end{array}$ & 1011111110000000000000000000000000000000 \\
\hline $\begin{array}{l}\text { Bothrio- } \\
\text { lepidae }\end{array}$ & 1111111110110000000001110100001011001111 \\
\hline $\begin{array}{l}\text { Astero- } \\
\text { lepidae }\end{array}$ & 1000000010100010000101110011011000100001 \\
\hline $\begin{array}{l}\text { 'Ctena- } \\
\text { canthidae' }\end{array}$ & 1000000001000001000010000000000001010000 \\
\hline $\begin{array}{l}\text { Machaeracan- } \\
\text { thus }\end{array}$ & 0000000000000000000000000000000000110000 \\
\hline $\begin{array}{l}\text { 'Dipte- } \\
\text { ridae' }\end{array}$ & 0100000000100000101111001101100101111101 \\
\hline $\begin{array}{l}\text { Osteo- } \\
\text { lepidae }\end{array}$ & 0101100010101001100111111100000001100001 \\
\hline
\end{tabular}

4423322241411123302445333412112214442225 taxa 
The highest resemblance (five taxa in common with the Venezuelan fauna) is shown by two localities: 22 (Koknese, Latvia), and 40 (Sjass River, Russia). It is noteworthy however that both these localities include psammosteid heterostracans, a major agnathan group characterising the Euramerican province (Young 1981), which has never been documented in Gondwana (Young in press). In fact, Euramerican endemic agnathans (osteostracans, heterostracans) occur in a majority of assemblages from Europe and North America (6 out of 10 localities; Schultze \& Cloutier 1996: fig. 1), but in no Gondwanan area.

Many more localities $(1,2,9,11,20-21,26$, 34-36) share four taxa in common with the Venezuelan fauna. These generally involve the combination of two widespread osteichthyan groups (dipterids and osteolepids) with two widespread antiarch placoderms (bothriolepids and asterolepids). In five instances (mainly marine assemblages) one of these groups is replaced by ptyctodontids, viz. localities 2 (Gogo, Western Australia), 20-21 (central Iran), 26 (Holy Cross Mtns, Poland), and 36 (18 Mile Ck, New York State). The last is anomalous compared to the others because the similarity derives instead from the presence of chondrichthyan and $M a$ chaeracanthus spines. It is of interest that although Machaeracanthus is very widespread in the Early Devonian, particularly in West Gondwana, by the late Givetian-early Frasnian it persists only at two other localities, both in North America (35, Red Hill, Nevada, and 36, 18 Mile Ck; see Schultze \& Cloutier 1996: appendix 1).

\section{Biogeographic affinities of the new fauna}

These broad comparisons based on higher level taxa probably reveal some general palaeoenvironmental similarities in the ichthyofaunal assemblages, with a suggestion that the Venezuelan fauna has closer affinity to North America than to other Northern Hemisphere localities. However those localities lack two key biogeographic indicators of Gondwanan affinity (pre-Famennian phyllolepids, and antarctilamnid sharks; see Young in press: fig. 3). The species Bothriolepis perija $\mathrm{n}$. sp. is described below to show affinity to other Gondwanan rather than to Northern Hemisphere species, but this relationship is subsumed within the family Bothriolepidae in the above data matrix. This is the most widespread family, occurring in a majority (22) of the 40 ichthyofaunas. Similarly, the Asterolepidae (14 localities) is represented in the Northern Hemisphere by the widespread Asterolepis, which, as noted above, is not confirmed outside of Euramerica (Janvier \& Villarroel 2000; the monophyly of the Asterolepidae is not strongly supported in any case). The new genus Venezuelepis described below is subsumed within the family Asterolepidae in the data matrix, although this new "asterolepid" is otherwise only known from East Gondwana (locality 1, Aztec fauna). Apart from these four out of 9 or 10 taxa in the Venezuelan fauna showing clear Gondwanan affinities, the osteolepid, dipterid, ptyctodontid and acanthodian (?Cheiracanthoides) remains can be considered widespread or cosmopolitan at the level of detail of this analysis.

Young et al. (2000b) summarised the new Venezuelan fish fauna biogeographically as an extension along the northern Gondwana margin of a distribution in time and space indicating a nonmarine dispersal episode between Gondwana and Euramerica during the Late Devonian. Homosporous plants were noted to have had probably a greater dispersal capacity than stenohaline fishes, which were constrained by narrow marine barriers, even if continental shelves were juxtaposed. Such an arrangement is required to explain the well-documented invertebrate faunal similarities between Venezuela and eastern North America during the Early-Middle Devonian, including the same brachiopod species (Benedetto 1984), and close similarities amongst trilobites and corals (e.g., Eldredge \& Ormiston 1979, Oliver \& Pedder 1989).

This "Appalachian Province", extending from eastern North into northwest South America (Venezuela, Colombia), contrasts with a cold water "Malvinokaffric Province" for the rest of South America, southern Africa, and Antarctica during the Early-Middle Devonian (Boucot 1975, Meyerhoff et al. 1996). As noted above, the Colombian and Venezuelan fish faunas, dominated by placoderms, contrast sharply with other "Malvinokaffric" fish assemblages from South America, which are dominated by acanthodians and chondrichthyans. The close similarities in the chondrichthyan spines described below, and those from the late Middle Devonian of Brazil (Janvier \& Melo 1992) may be a late manifestation of this Malvinokaffric element. 


\section{Palaeogeographic} and palaeotectonic reconstructions

A narrow marine barrier between Gondwana and Euramerica by Givetian-Frasnian time, with land connection by the Famennian, is at variance with well-publicised continental reconstructions based on palaeomagnetic data ( $\mathrm{Li}$ et al. 1993, Van Der Voo 1988, 1993, Tait et al. 2000). These postulate a wide Late Devonian ocean, with both northern Africa and northwestern South America at about $50^{\circ}$ south latitude in the Late Devonian. Such reconstructions are strongly contraverted by patterns of Devonian fish distribution in time and space, and by a range of other palaeontological and other data (Young et al. 2000a, b, Young in press). Lelièvre et al. (1993) considered the possibility that the Arabian platform may have been extended northward by a number of microplates, and would have first established palaeogeographic contact with the Northern Hemisphere blocks. However the North American occurrences of Machaeracanthus noted above, perhaps reflecting the pattern indicated by diverse macroplant assemblages (Berry et al. 1993), is evidence favouring an initial contact between northwestern Gondwana and eastern North America.

A complicating factor concerns the structurally complex Palaeozoic geology of the northern Andes and Sierra de Perijá, and the possibility that the region of western Venezuela may be allochthonous (Maze 1984), and did not form the northwestern margin of South America in the Devonian. Restrepo \& Toussaint (1988) proposed an "Eastern Andean Terrane" including the Sierra de Perijá, which may not have accreted to the northwestern margin until the Jurassic. Another scenario (Forero 1990) proposes an allochthonous fragment derived from North America, and accreted to the Gondwanan margin during the Siluro-Devonian Caledonian orogeny resulting from collision between Laurentia and Gondwana (see also Dalziel et al. 1994). In contrast, Mojica \& Villarroel (1990) considered the Palaeozoic strata across northwestern South America to have consistent lateral facies relationships, indicating development in place rather than allochthonous origin. The biogeographic affinities of our new fish fauna would exclude an origin of this Mid-Late Devonian Venezuelan sequence from outside of Gondwana, unless accretion took place well before the Middle Devonian. Note also that well-documented biogeographic patterns of early vertebrates
(Young 1981, 1990) strongly contradict a SiluroDevonian (Caledonian) collision between Laurentia and Gondwana (see Young et al. 2000a).

\section{Systematic palaeontology}

Class Placodermi M'Coy, 1848

Order Antiarchi Cope, 1885

Suborder Bothriolepidoidei Miles, 1968

Family Bothriolepidae Cope, 1886

Genus Bothriolepis Eichwald, 1840

\section{Bothriolepis perija n. sp.}

Figs $3-8,9 \mathrm{~A}-\mathrm{F}, 10 \mathrm{~A}, \mathrm{~B}$

Synonyms:

1980 "restos óseos fragmentarios"; "fragmentos de tetrápodos (?laberintodontes)" - Benedetto: 831, 834 (in part)

1992 Bothriolepis - Casas, Moody \& Young: fig. 12.

1997 "restos de Bothriolepis" - Berry, Casas, Moody \& Young: 128

2000 Bothriolepis - Young, Moody \& Casas: 758, fig. 2A.

Holotype: MBLUZ P-182, an articulated armour preserved in ventral view.

Other material: A full listing of field identifications of Bothriolepis bones in the collection is given in the Appendix. Studied material and other samples mentioned in the descriptions are listed here: MBLUZ P-188, $210(\mathrm{Nu})$; P-103 (PNu, PM); P-43, P-168 (La); P-274 (PrM); P-229 (SM); P-52, 195 , 224, 228, 244 (AMD); P-232, 245, 320 (PMD); P-179, 236 (MxL); P-185, 191, 228, 260, 261 (AVL); P-195, 230, 320 (PVL); P-177 (MV); P-173, 197, 230 (pectoral fin bones).

Locality and horizon: All from locality 139, Caño Colorado Sur, in the upper member of the Campo Chico Formation (Fig. 1).

Diagnosis: A Bothriolepis with a median dorsal armour length of at least $100 \mathrm{~mm}$. Skull possibly with trilobate preorbital recess. PrM with straight rostral margin, indistinct infraorbital sensory grooves, and an extra groove (ethmoid commissure) passing anterolaterally. Central sensory groove commonly double on $\mathrm{La}$ and $\mathrm{Nu}$ plates. $\mathrm{Nu}$ with anteriorly placed ossification centre, and occipital cross commissure well in front of obtected nuchal area. B/L indices of PrM about 110 , and $\mathrm{La}$ about 75 . L/B index of $\mathrm{Nu} 75-90$. La with internal ridge supporting separate elongate anterior SM attachment. SM with convex dorsal margin, expanded posterodorsal process, and strongly convex ventral margin. $\mathrm{B} / \mathrm{L}$ index of AMD 86-105, and PMD 104-120; visceral surface of AMD with up to three pairs of posterolaterally curved vascular grooves. MxL relatively high, with laminae meeting at an obtuse 

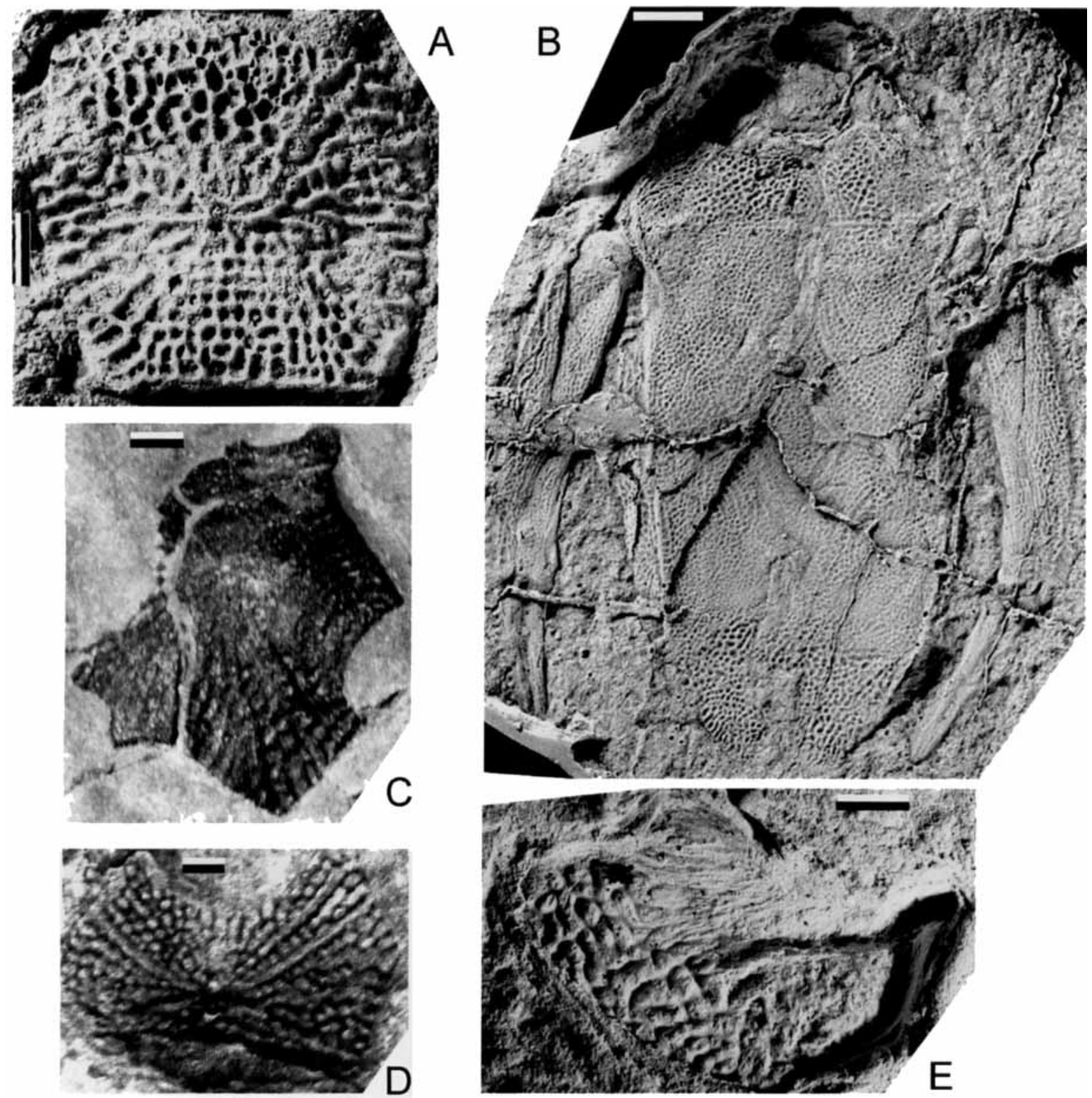

Fig. 3. Bothriolepis perija n. sp. A. PrM plate, external view (MBLUZ P-274, $\times 6$ ), B. holotype in ventral view (MBLUZ P-182, $\times 2$ ). C. Left La plate, external view (MBLUZ P-43, ×2.5). D. Nu plate external view (MBLUZ P-210, ×3). E. Right SO plate, external view (MBLUZ P-229, $\times 5$ ). A,B,E are latex casts whitened with ammonium chloride. Scale bar $=2 \mathrm{~mm}$ for $\mathrm{A}, \mathrm{D}, \mathrm{E} ; 3 \mathrm{~mm}$ for $\mathrm{C} ; 5 \mathrm{~mm}$ for $\mathrm{B}$.

angle, an unusually broad sensory groove, and a deep ornamented part of the lateral lamina; L/B indices for dorsal and lateral laminae about 168 and 220 . Ventral wall of trunk armour elongate (L/B index 220-240), with $\mathrm{L} / \mathrm{B}$ indices of 165 and 208 for ventral laminae of AVL and PVL. Subcephalic division of AVL about $29 \%$ of total length. MV with longer posterior than anterior division. Ornament reticulate and nodose.

Remarks: Dermal plates of Bothriolepis are readily recognised in the Caño Colorado Sur material by their typical reticulate and nodose ornament (as defined by Young 1988a: 19). Most occur as disarticulated bones. Some were clearly broken before preservation in the sediment, others seem to be scattered remains from one individual, and one specimen shows an articulated armour, and is selected as the holotype (MBLUZ P-182). Some features (e.g., preorbital recess) are only preserved in the holotype. It was not practicable to prepare and study the entire collection, but most specimens were superficially examined. The evidence obtained so far is consistent with the presence of a single new species.

Description: The holotype is a small articulated specimen of which the ventral side of the armour is best preserved (Casas et al. 1992: 


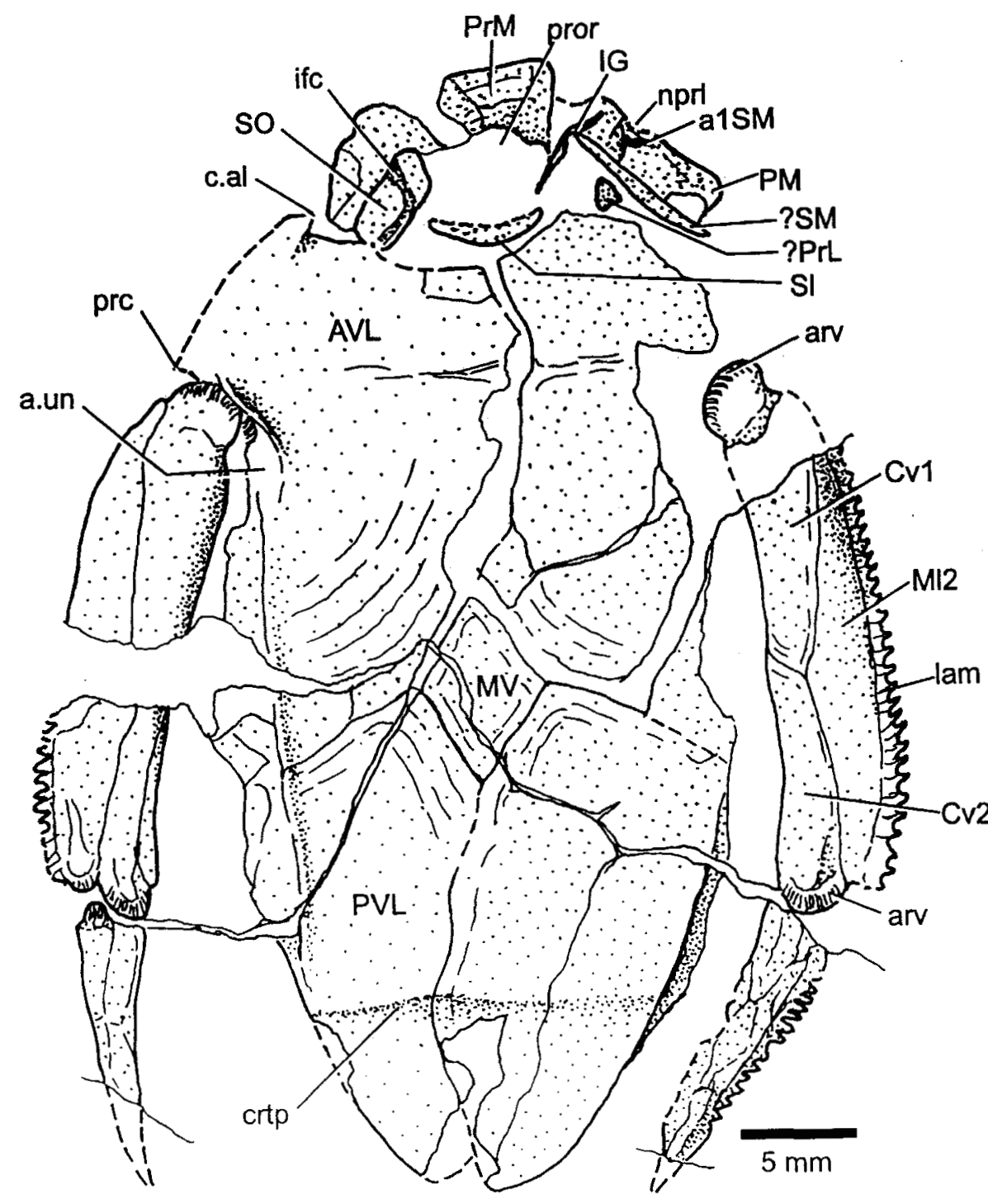

Fig. 4. Bothriolepis perija n. sp. MBLUZ P-182 (holotype) in ventral view. fig. 12). This has been studied mainly from a latex cast of the ventral impression (Fig. 3B), which shows the skull roof poorly exposed in visceral view, together with ventral bones of the trunk armour, and both pectoral fins, all slightly displaced and somewhat crushed. The left fin is complete except for the extremity of its distal segment (Fig. 4). The dorsal surface of the armour is presumably intact within the matrix, but this major preparation task could not be attempted.

Skull, cheek, and jaws. The visceral surface of the margins of the skull in the holotype are poorly exposed, and only the lateral parts of the left La plate, and the front of the PrM, show some details. The broken ventral margin of a bone on the left side may be from the cheek (?SM, Fig. 4). Beneath it is a faint impression which from its size might be a prelateral plate (?PrL), and another thin impression may be the lower jaw bone (IG). On the right side is a bet- ter impression of the SO, approximately in position by comparison with specimens of $B$. canadensis (Stensiö 1931: fig. 23). It shows the characteristic sensory groove curving from the ventral up to the dorsal margin (ifc), but bone edges are poorly preserved, and there are no significant differences to the $\mathrm{SO}$ in other forms (Stensiö 1948: fig. 35, Young 1988a: fig. 20E). Behind the rostral margin of the skull a sedimentary infill possibly indicates a trilobate shape for the preorbital recess (pror; Fig. 4), although this needs to be confirmed with additional material. A recess of this shape has previously been identified only in some Antarctic and Australian species (Young 1985, 1988a), suggesting that it could be a feature of East Gondwana species (synapomorphy ' $\mathrm{e}$ ' of Young 1988a: fig. 68). However there is some uncertainty about the condition in B. cellulosa as restored by Stensiö (1948: fig. 14), where it was given a similar semicircular shape to the recess of $B$. canadensis. The specimens on 
which the restoration is based (Stensiö 1948: figs 218, 221B) show some suggestion of approaching the trilobate shape, particularly as earlier figured by Gross (1941: pl. 2, fig. 2; also pl. 6, fig. 2). Stensiö (1948: 412) also noted that the median division of the recess in $B$. cellulosa was more convex than in $B$. canadensis.

The morphology of skull in the holotype is supplemented by a small number of disarticulated bones. The rostral margin shows no anterior angle, and the external surface of the PrM is well shown by one small disarticulated specimen (P-274B; Fig. 3A). This is just slightly larger (L $9 \mathrm{~mm}$ ) than the isolated PrM of B. askinae figured by Young (1988a: pl. 1, fig. 8), and it has similar proportions $(B / L$ 111). It resembles the holotype in its fairly straight rostral margin, which lacks a rostral angle (this angle is a juvenile characteristic in $B$. canadensis, reduced or lost in larger specimens). Various examples of the PrM of $B$. canadensis, which are both slightly smaller and larger than this specimen, may also have straight rostral margins, so this is not a significant character. However a consistent difference to the figured PrMs of $B$. canadensis (Stensiö 1948: fig. 85) is their more clearly incised sensory groove. In P-274 it is poorly defined, and shows possibly a more primitive arrangement than previously described for Bothriolepis. The infraorbital canal is indistinct, as a slightly wider groove between the ornament ridges passing laterally off the plate (ifc, Fig. 10B). A short separate groove immediately in front extends anterolaterally on both sides, presumably continuing anteriorly in soft tissue, to connect with the groove on the SO plate. This would be equivalent to the ethmoid commissure connecting the suborbital branch of the infraorbital groove (see Young \& Zhang 1996: fig. 14). This unusual arrangement can be compared with juvenile $B$. askinae, where two separate grooves may also develop, but in that case they both pass off the lateral margins of the plate (Young 1988a: pl.1, fig. 1). In other Bothriolepis the sensory groove on the $\operatorname{PrM}$ is typically strongly developed, without extra branches. Another unprepared PrM plate listed in the Appendix (P-323) has not been studied. Details of the visceral surface are not preserved on these specimens.

The La plate is partly known from the holotype, which shows a ridge supporting an elongate anterior attachment area for the SM (a1SM, Fig. 4), as in some Antarctic species, and unlike $B$. canadensis (see Young 1988a: fig. 66). An isolated
SM plate described below also resembles some Australian and Antarctic species in shape, rather than that of $B$. canadensis. In the Bothriolepis from Colombia described by Janvier \& Villarroel (2000) a different articular arrangement is seen, which compares instead with Bothriolepis from Gogo, WA (e.g., Young \& Zhang 1996: fig. 13E). The ventral pit is not clearly seen on the holotype of $B$. perija, but was presumably small.

The best preserved disarticulated La plate $(\mathrm{P}-43)$ is the specimen previously figured by Young et al. (2000b: fig. 2A), the first specimen of Bothriolepis to be identified from South America (see Introduction). It shows most of the external surface, only lacking part of the lateral margin (Fig. 3C). Restored $\mathrm{B} / \mathrm{L}$ index is about 75 , within the range of variation for $B$. canadensis (60-80; Stensiö 1948: 254). However it is clearly a broader plate than in several Antarctic species (B. askinae, B. barretti, B. kohni, B. portalensis; Young 1988a). It is also evidently broader than the two La plates recently illustrated from Colombia by Janvier \& Villarroel (2000: fig. 7A, B), which they considered may belong to separate species. The orbital margin (orb, Fig. 5A) is relatively large, and the length of the premedian suture relatively short ( $\mathrm{Nu}$ suture $64 \%$ its length), compared to those Antarctic species with a long preorbital division (e.g., $B$. portalensis, B. vuwae, B. karawaka). The embayed premedian margin presumably corresponds to an overlap for that bone (oaPrM, not preserved). The sensory pattern shows a double central sensory line (csl), which is more commonly encountered in juveniles of Bothriolepis. A second very incomplete example, which lacks the entire lateral division (Fig. 5B), is noteworthy in displaying a similar large orbital notch, and also a double central sensory groove (csl). Of other examples of the La plate listed in the Appendix, specimen P-192 (poorly preserved) displays the visceral surface, associated with an incomplete $\mathrm{Nu}$ possibly from the same individual. Specimens P-237, 252 are incomplete and unprepared, and show no useful features.

The La plate fits well within the range of variation documented for $B$. canadensis (cf. Stensiö 1948: fig. 89), except perhaps for a narrower lateral division, and a more pronounced anterior postmarginal corner (cpm1). The latter feature is seen in some Antarctic species, for example $B$. askinae or B. mawsoni (Young 1988a: pl.3, fig. 6, pl. 14, fig. 4). However both clearly differ in the smaller orbital notch, and B. mawsoni has a much longer premedian margin. There are no 

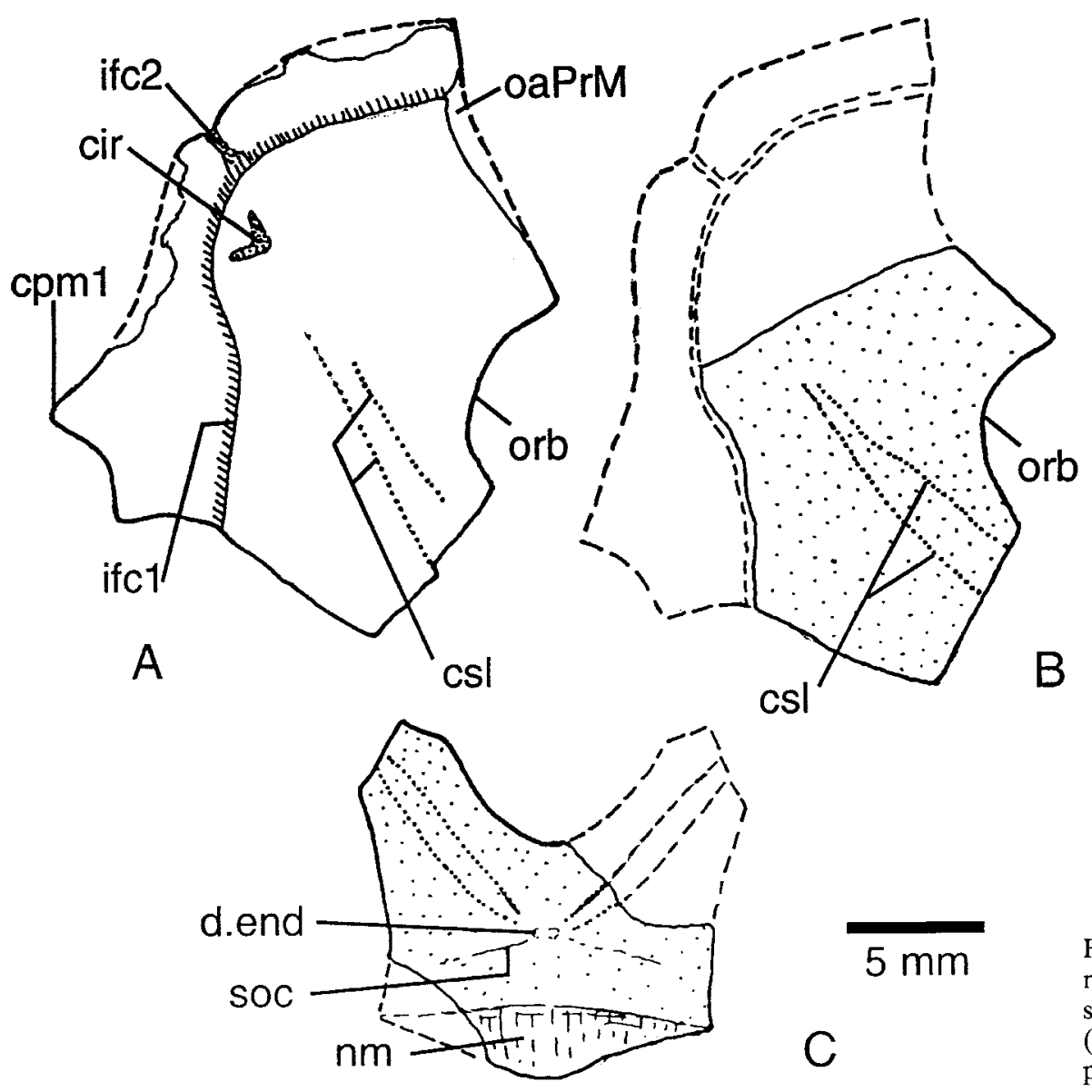

Fig. 5. Bothriolepis perija n. sp., camera lucida drawings of isolated skull bones. A, B. Left La plates (MBLUZ P-43, P168B). C. Nu plate (MBLUZ P-188).
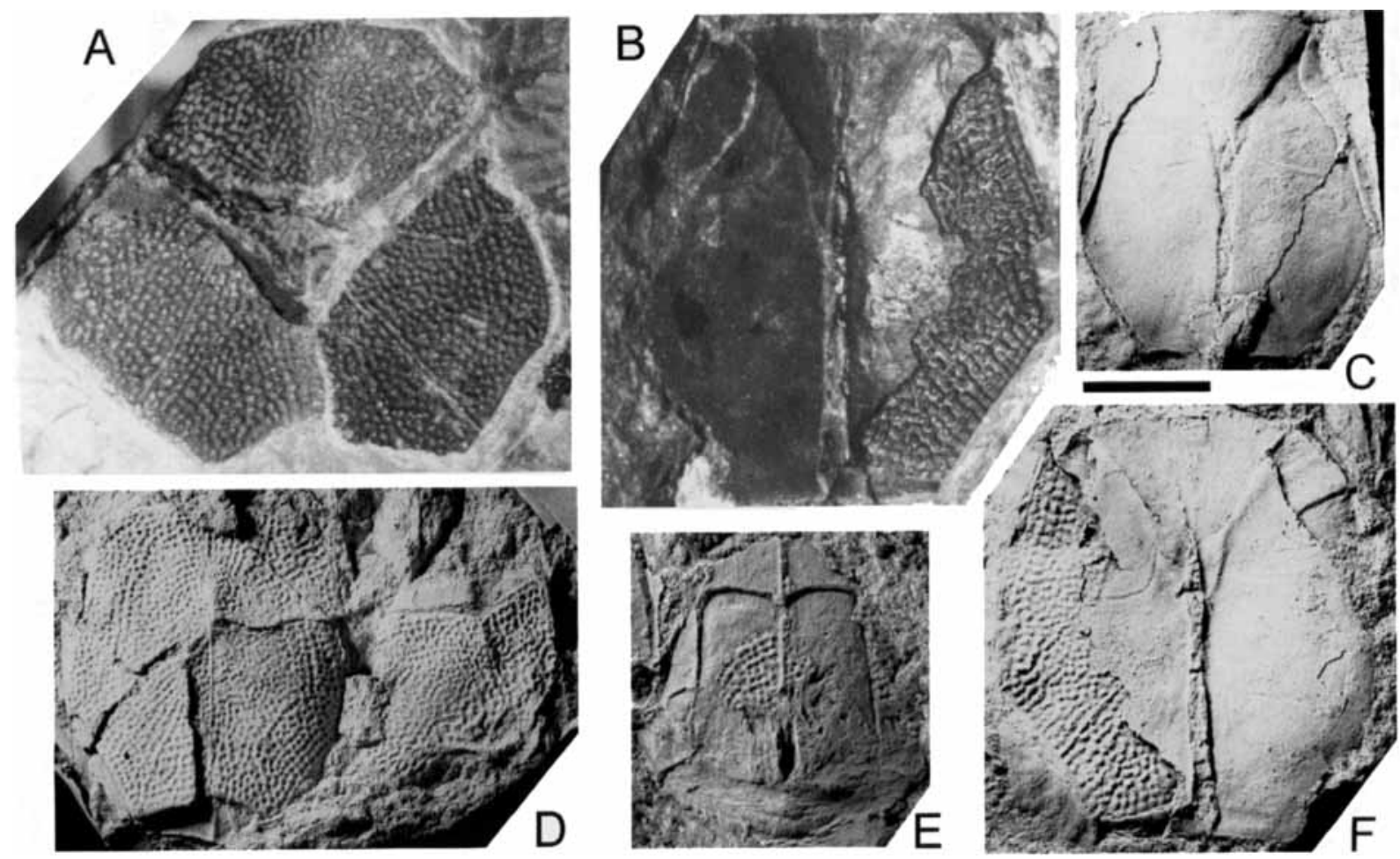

Fig. 6. Bothriolepis perija n. sp., isolated AMD plates (A-D, F) and a PMD (E) from the trunk armour. A. External view (MBLUZ P-52). B. Part impression of inner surface (MBLUZ P-195). C. Internal impression (MBLUZ P-224). D. External impression, with incomplete AVL plate (MBLUZ P-228). E. Internal impression (MBLUZ P-320). F. Inner surface, with part of external impression (MBLUZ P-195B). All specimens $\times 1.5$. C $-\mathrm{F}$ are latex casts whitened with ammonium chloride. Scale bar $=10 \mathrm{~mm}$. 
obvious distinguishing features from the La of $B$. cellulosa of similar size (e.g., Gross 1941: pl. 4, fig. 7), although proportions are more elongate (B/L 60-75; Stensiö 1948: 414). The incomplete La plates illustrated from Colombia by Janvier \& Villarroel (2000: pl. 1, figs 4-5) are smaller than the specimens described here, with finer, more reticulate ornament.

The only $\mathrm{PNu}$ plate identified (P-103) is part of an incomplete left posterolateral skull fragment, which includes the preobstantic corner and PM plate. It shows no significant differences from illustrated examples of $B$. canadensis (Stensiö 1948: figs 99-100).

Of the two studied examples of the $\mathrm{Nu}$ plate, P-210 (Fig. 3D) is a relatively complete small bone $11 \mathrm{~mm}$ long (L/B 76). An incomplete slightly larger specimen can be reconstructed (Fig. 5C) to indicate a narrower plate (L/B 89), consistent with the well-documented decreasing breadth with size in the $\mathrm{Nu}$ of $B$. canadensis (Stensiö 1948: 257). Both specimens also show a double sensory groove, as noted above on the La plate. The anterior position of the ossification centre and presumed endolymphatic duct openings (d.end, not clearly preserved), with the occipital cross commissure (socc) well in front of the obtected nuchal area (nm), may be points of difference from $B$. canadensis. It is probable that the $\mathrm{Nu}$ was more elongate than in $B$. canadensis, where the $\mathrm{L} / \mathrm{B}$ index is reported to vary from $65-71$ in smaller and up to 83 in large specimens. Two Nu plates from the Colombian Upper Devonian fish fauna illustrated by Janvier \& Villarroel (2000: pl.1, figs 3, 4) also apparently have endolymphatic duct openings and ossification centres in an anterior position, but seem less arched than the Venezuelan specimens. Other examples of the $\mathrm{Nu}$ plate listed in the Appendix include several associated with AMD and other bones possibly from the same individual (e.g., MBLUZ P-195, 224; AMD's illustrated in Figs 6B-C), and MBLUZ P-201, an unprepared specimen with PP attached.

Apart from the poorly preserved SO plate on the holotype, the cheek of $B$. perija is represented by one isolated left SM plate (MBLUZ P-229A; Fig. 3E). This small bone (length $13 \mathrm{~mm}$; depth nearly $8 \mathrm{~mm}$; L/B 160 ) is quite different in shape from the corresponding element of $B$. $c a$ nadensis. It has a convex dorsal margin, with an expanded posterodorsal process (ad2, Fig. 10A), thus resembling various Antarctic and Australian species (Young 1984b: pl. 57, 1988a: figs 18, 55, Johanson \& Young 1999: fig. 3L). In contrast, in
B. canadensis the SM is much more elongate (Stensiö 1948: fig. 32), being at least 2.5-3 times as long as broad, with relatively straight dorsal and ventral borders. MBLUZ P-229 has a strongly convex ventral margin, more convex than in B. askinae (the small specimen illustrated by Young 1988a: fig. 18). It also differs from various other species in which the SM is known (see Johanson 1998: fig. 11) in the posterior position of the posterodorsal process. A groove running back from beneath the anterodorsal process (gr, ad1, Fig. 10A) is seen in the Antarctic species B. macphersoni (Young \& Zhang 1992: fig. 9A). That species also has a large area above $(\operatorname{ad} 2)$ with a striated rather than tuberculate surface (Fig. 3E), but it differs in the less convex ventral margin.

The configuration of the dorsal margin of the SM, with an expanded posterodorsal process, must relate to the different morphology of cheek attachments on the skull discussed by Young (1988a: fig. 66). These morphological details are poorly known in most Northern Hemisphere species (e.g., the SM is unknown in B. cellulosa; Gross 1941), but where information is available, the data show that $B$. perija differs from $B$. canadensis, and resembles various Antarctic and Australian species as discussed above.

Trunk armour and pectoral fins. The ventral wall of the trunk armour in the holotype is about $47 \mathrm{~mm}$ long, and may be compared with a slightly smaller specimen of the Antarctic species B. askinae. This is similarly preserved (Young 1988a: pl. 3, fig. 9), but lacks the PVLs. In the midline of P-182 the right AVL plate overlaps the left (Fig. 4), and the left PVL overlaps to the right, the normal arrangement for $B o-$ thriolepis. The MV and both PVLs are in position, and the semilunar plate is slightly displaced from its notch (Sl). The anterior margins of the AVLs are not well preserved, but the right plate shows the anterolateral corner (c.al) adjacent to a distinct mesial notch, which in articulated $\mathrm{Bo}$ thriolepis from Gogo is positioned immediately behind the infraprelateral plate of the cheek unit (Young 1984b: fig. 1F). The position of the prepectoral corner (pre) can be inferred from the articulated fin segment, adjacent to which is an unornamented area on the AVL (a.un), as described in other forms. The midline overlap of the right AVL onto the left is associated with a slight transverse lineation marking the position of the transverse crista on the inner face, as previously illustrated (Stensiö 1948: fig. 163). A 
transverse depression crosses the PVL plates, to mark the position of the posterior transverse crista (crtp). $\mathrm{L} / \mathrm{B}$ indices for the ventral laminae are 165 for the AVL and 208 for the left PVL. The subcephalic division of the AVL is about $29 \%$ the length of the plate. The lateral laminae of the ventolateral plates are crushed and poorly preserved in the holotype, so no proportions could be determined.

The restored ventral wall has a $\mathrm{L} / \mathrm{B}$ index estimated in the range of 220-240. Thus it could be somewhat more elongate than in $B$. canadensis, where the ventral wall length is a little above and below twice the breadth (Stensiö 1948: 231; cf. figs $160-162,168)$. The ventral armour restoration of the Colombian Bothriolepis (Janvier \& Villarroel 2000: fig. 9B) is considerably broader in proportion, but was based only on disarticulated plates, so this may not be a reliable difference.

Dorsal bones of the trunk armour are only represented by isolated bones (Fig. 6). AMD plates are common in the collection, and five examples have been studied (MBLUZ P-52, 195, $224,228,244$ ). All are of similar size (L $26-33 \mathrm{~mm}$ ). The $\mathrm{B} / \mathrm{L}$ index ranges from 86 in the smallest to 105 in the larger specmens, which is within the total range for $B$. canadensis (76-112; Stensiö 1948: 287), even though these are all less than the average size for that species. In $B$. canadensis there is a well-documented proportional increase of breadth with size, and considerable shape variation (Stensiö 1948: figs 121-124). However smaller specimens, of similar size to the material described here, normally have a $\mathrm{B} / \mathrm{L}$ index in the range 80-100. This suggests that in $B$. perija the AMD may have been broader than in $B$. canadensis for its size; large AMD's of the latter species, with similar proportions to this material, are almost twice the length (60-75 mm long).

The external surface in a smaller AMD (MBLUZ P-228) shows strongly reticulate ornament on a fairly flat plate lacking a distinct med-
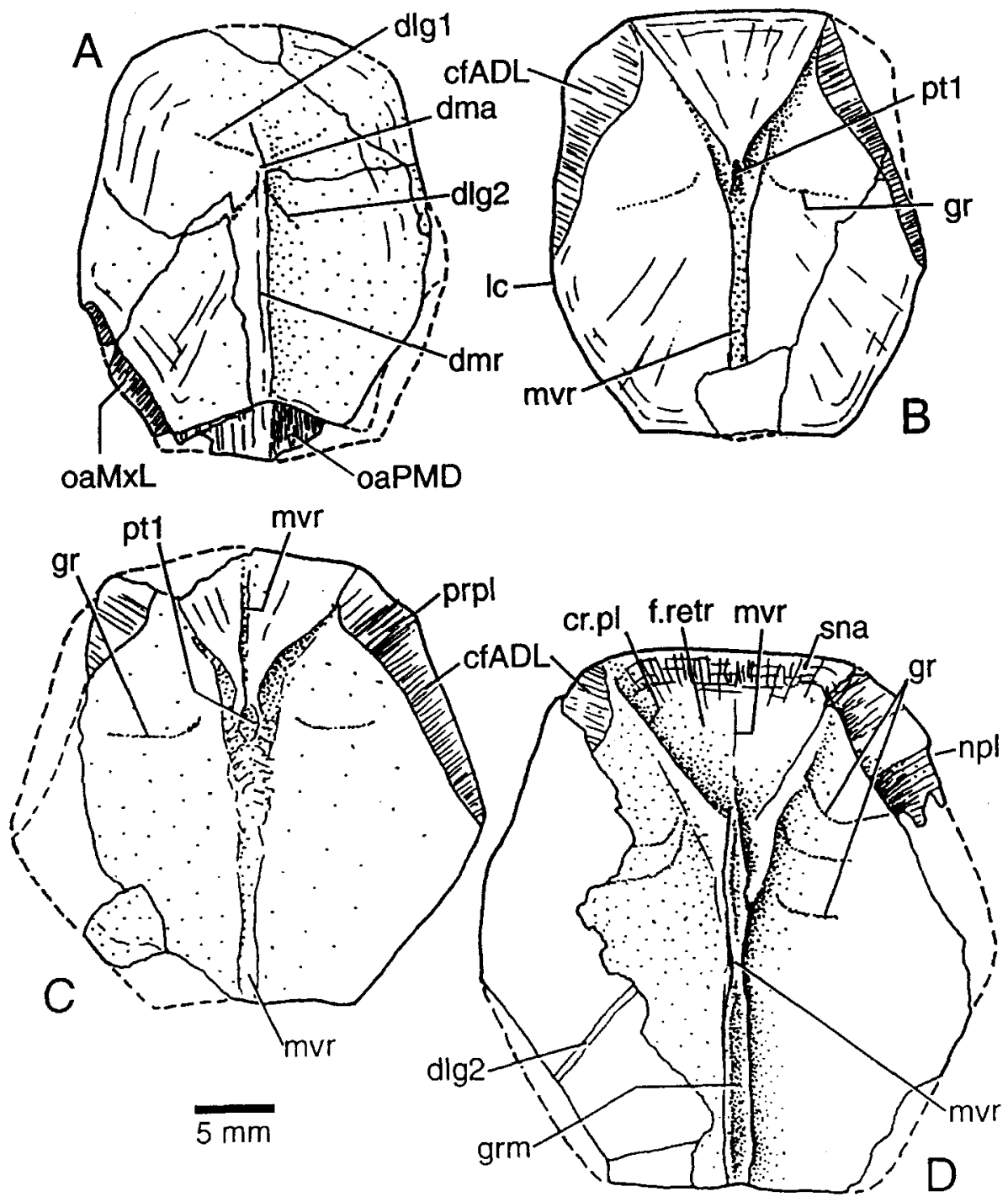

Fig. 7. Bothriolepis perija n. sp. Camera lucida drawings of AMD plates in dorsal (A) and ventral views. A. MBLUZ P228. B. MBLUZ P-244. C. MBLUZ P-224. D. MBLUZ P195. 
ian dorsal ridge (Fig. 6D). The midline has only a single continuous ornamental ridge, no more prominent than the surrounding ornament. This bone is unusual in that sensory grooves are obscure, and only discernable near the tergal angle (dlg1,2, Fig. 7A). However they are seen on other examples (Fig. 6). The lateral corners may be rounded (lc), and the postlevator process (prpl) and notch (npl) are indistinct.

MBLUZ P-224 and P-244 show inner surface impressions of the AMD, and the inner bone surface is partly preserved in P-195. General morphology (Fig. 7B-D) compares well with $B$. canadensis (Stensiö 1948: fig. 449). The levator fossa (f.retr) is delimited by postlevator cristae, and has a median ventral ridge (mvr) and a broad subnuchal area (sna). Posteriorly the ventral ridge seems to be more strongly developed than in either B. canadensis or B. cellulosa (e.g., Gross 1941: pl. 9, fig. 1). In B. perija it forms a thickened continuous structure, with a shallow groove on the ridge, rather than on the plate (grm). The anterior ventral pit is broken, but is seen as an impression in MBLUZ P-224 and P244 (pt1). All examples show slight grooves (presumably vascular) curving posteriorly and laterally from the region of the ossification centre (gr); in MBLUZ P-195 at least three pairs are developed (Fig. 7D). This feature was described in Monarolepis from southeastern Australia by Young \& Gorter (1981), and noted in Antarctic species (Young 1988a: fig. 29B). It may also occur in some northern hemisphere species (e.g., Stensiö 1948: figs 44, 126F), but would appear to be more consistently present in $B$. perija than in previously described material. Small AMD plates from Colombia (up to $25 \mathrm{~mm}$ long) were illustrated by Janvier \& Villarroel (2000), and show no significant differences to the material described here. The external surface shows a similar ornamental ridge in the midline, and the inner surface of several examples is similarly developed, with the anterior pit and median ventral groove. One unusually narrow specimen (Janvier \& Villarroel 2000: pl. 1, fig. 12) seems to have proportions elongated by distortion, but other examples may have been broader than $B$. perija for their size ( $\mathrm{B} / \mathrm{L}$ indices close to 100$)$.

Studied examples of the PMD (MBLUZ P$232,245,320)$ are again of similar size (L 20, 25 , $23 \mathrm{~mm}$ ). They may be proportionately broader than in B. canadensis (estimated $\mathrm{B} / \mathrm{L}$ 104-120). The largest specimen (MBLUZ P-245) has a restored $\mathrm{B} / \mathrm{L}$ index of about 120 ; in the much larger sample of $B$. canadensis it ranges between
$77-117$, and is broadest in much larger individuals. Several Antarctic species (e.g., B. askinae, B. kohni, B. portalensis) also have relatively broad PMDs (Young 1988a: table 3). The external surface partly displayed in P-245 shows the flat form, insignificant median dorsal ridge $(\mathrm{dmr}$, Fig. 8B) and reticulate ornament, which match well with the AMD, consistent with the assumption that they are conspecific. The incomplete external surface of MBLUZ P-232 is unusual in showing an overlap area for the $\mathrm{MxL}$ along the anterior preserved part of its left margin. This is more extensive than the "notches" occasionally recorded in this position in B. canadensis (Stensiö 1948: figs 138-139).

The inner surface of the PMD (Fig. 6E), displays an elongate posterior pit (pt2, Fig. 8A-B), which was more clearly defined and better developed than the pit on the AMD. It lies close to the transverse crista (crtp), such that a posterior ventral process is not developed. In these features the PMD is similarly developed to other species, including the few examples illustrated from Colombia by Janvier \& Villarroel (2000).

No good examples of the ADL have been studied. The MxL is represented by two specimens preserved in part and counterpart. Measurements for MBLUZ P-179 give approximate proportions for the dorsal and lateral laminae $(\mathrm{L} / \mathrm{B}$ 168,220 ), within the total range given for $B . c a$ nadensis (Stensiö 1948: 319). Both specimens are clearly higher and broader than in most illustrated material of that species (Fig. 9A, B). In particular, the laminae met at an obtuse angle, rather than almost a right angle for $B$. canadensis. B. perija resembles several Antarctic species with similar high MxL plates (e.g., Young 1988a: fig. 13, pl. 5, fig. 7), also the Australian B. longi (Johanson \& Young 1999: fig. 2A), or various Northern Hemisphere species (e.g., B. turanica), all of which differ from $B$. canadensis in having a higher trunk armour. The MxL plate from Colombia illustrated by Janvier \& Villarroel (2000: pl. 2, fig. 8) is of quite different form to those described here, with a more elongate dorsal lamina, and a low angle between laminae, as in $B$. canadensis.

The external surface of the MxL shows the normal overlap areas and sensory grooves $(\mathrm{lcg}$, dlg2, Fig. $8 \mathrm{~F}$ ), but the lateral line groove is unusually broad, and the overlap is reduced. Reticulate ornament closely matches that on the AMD and PMD. MBLUZ P-179B is better preserved (Fig. 9B), with a small extra overlap for the AMD, as seen occasionally in other species (e.g., 


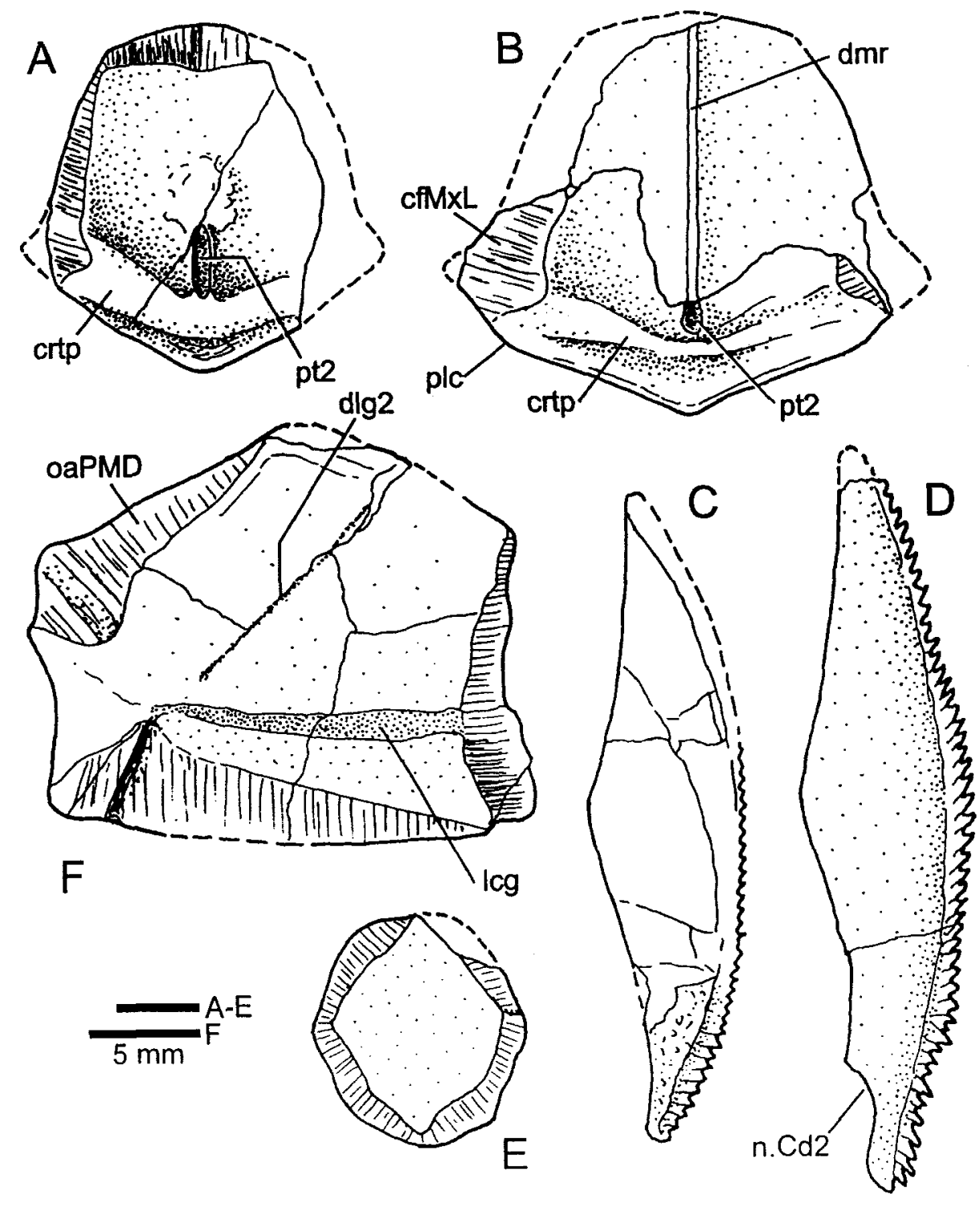

Fig. 8. Bothriolepis perija $\mathrm{n}$. $\mathrm{sp}$. Camera lucida drawings of isolated trunk armour and pectoral fin bones. A. MBLUZ P$232 \mathrm{~A}, \mathrm{PMD}$ in ventral view. $\mathbf{B}$. MBLUZ P-245A, PMD in dorsal view, partly preserved as an impression of the visceral surface. C. MBLUZ P197B, left M12 plate of pectoral fin, ventral view. D. MBLUZ P-230B, right $\mathrm{Ml} 2$ plate of pectoral fin, dorsal view. E. MBLUZ P177A, MV plate, ventral view. F. MBLUZ P-236B, right $\mathrm{MxL}$ plate, lateral view.
B. canadensis, Stensiö 1948: fig. 119D). This specimen also shows the unusually broad sensory groove, and an even deeper ornamented part of the lateral lamina, both of which might be specific characters.

Apart from the holotype, the AVL is represented on MBLUZ P-228 by a broken left ventral lamina showing the overlap area for the right plate (Fig. 6D), which probably comes from the same individual as the AMD described above. Several unprepared examples listed in the Appendix (MBLUZ P-185, 191, 260, 261) include AVLs in ventral view with attached pectoral fin segments.

Isolated PVLs are represented on MBLUZ P320 , which shows a right plate (L $36 \mathrm{~mm}$ ) preserved mainly as an impression of the badly crushed inner surface (Fig. 9E), and P-195C which is a well preserved right lateral lamina, this aspect not preserved on the holotype. The anterior overlap for the ADL is missing (Fig. 9D), and although incomplete it seems unusually short (estimated L/B 150) compared to other species (e.g., Stensiö 1948: 331, Young 1988a: table 3). A PVL from the Colombian locality seems also to have a rather deep lateral lamina (Janvier \& Villarroel 2000: pl. 2, fig. 8). MBLUZ P-230 (unprepared) probably includes associated left and right PVL plates from one individual. The MV is represented by an almost complete disarticulated example (MBLUZ P177A; Fig. 9C). Comparison with the holotype indicates that it had a longer posterior than anterior division (Fig. $8 \mathrm{E}$ ), as in B. cellulosa, and in contrast to $B$. canadensis (anterior division longer) or $B$. groenlandica, where they are of similar size (Stensiö 1948: 141).

There are many isolated pectoral fin bones in the material (see Appendix). Examples are MBLUZ P-173, an almost complete Cv2 plate, 
and P-197 and P-230, M12 plates exposed in ventral and dorsal views respectively (Fig. 8C, D), the latter suggesting an elongate $\mathrm{Cd} 2$, perhaps similar to that of B. askinae (Young 1988a: fig. 17). In the holotype the complete pectoral fins are well displayed (Fig. 3B). The proximal segment has a strong lateral spine row (lam, Fig. 4) on the lateral marginal plate (M12), which shows the normal suture arrangement to the two ventral central plates $(\mathrm{Cv} 1,2)$. Proximal and distal articular surfaces are displayed on these bones (arv) at the brachial and distal articulations. The proximal segment is about four times as long as broad, within the range of medium sized individuals of $B$. canadensis (Stensiö 1948: 359 ), and the same proportion as in the restoration for the Colombian material (Janvier \& Villarroel 2000: fig. 9A).

The distal segment is more complete on the left fin, but bone sutures are difficult to discern. There is some faint longitudinal ribbing, which is not as strong as on the distal segment in some
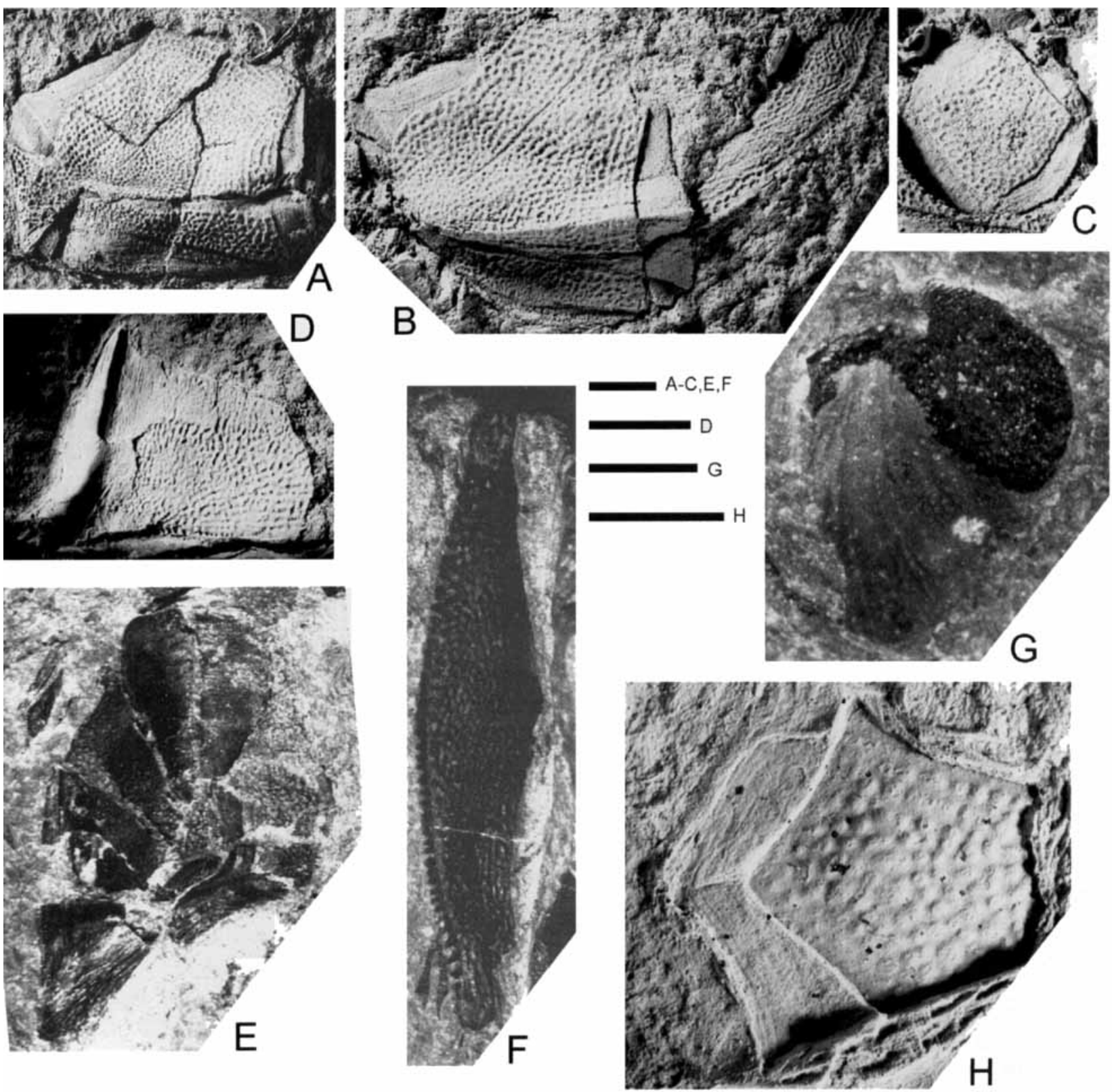

Fig. 9. Bothriolepis perija $\mathrm{n}$. sp. $(\mathbf{A}-\mathbf{F})$ and Venezuelepis mingui n.gen. and n.sp. $(\mathbf{G}-\mathbf{H})$, isolated bones. A. Right $\mathrm{MxL}$, external view (MBLUZ P-236B). B. Right MxL, external view (MBLUZ P-179B). C. MV plate, external view (MBLUZ P-177A). D. Lateral lamina of right PVL, external impression, (MBLUZ P-195). E. Left PVL, mainly an internal impression (MBLUZ P-320). F. Left M12 plate, dorsal view (MBLUZ P-230). G. Left Cd1 plate, mainly an internal impression (MBLUZ P-243). H. Possible incomplete left PL plate (MBLUZ P-200B). A-D, H are latex casts whitened with ammonium chloride. Scale bar $=5 \mathrm{~mm}$ for A-C, E, F $(\times 2) ; 10 \mathrm{~mm}$ for $\mathrm{D}(\times 3) ; 4 \mathrm{~mm}$ for $\mathrm{G}, \mathrm{H}(\times 4, \times 5)$. 

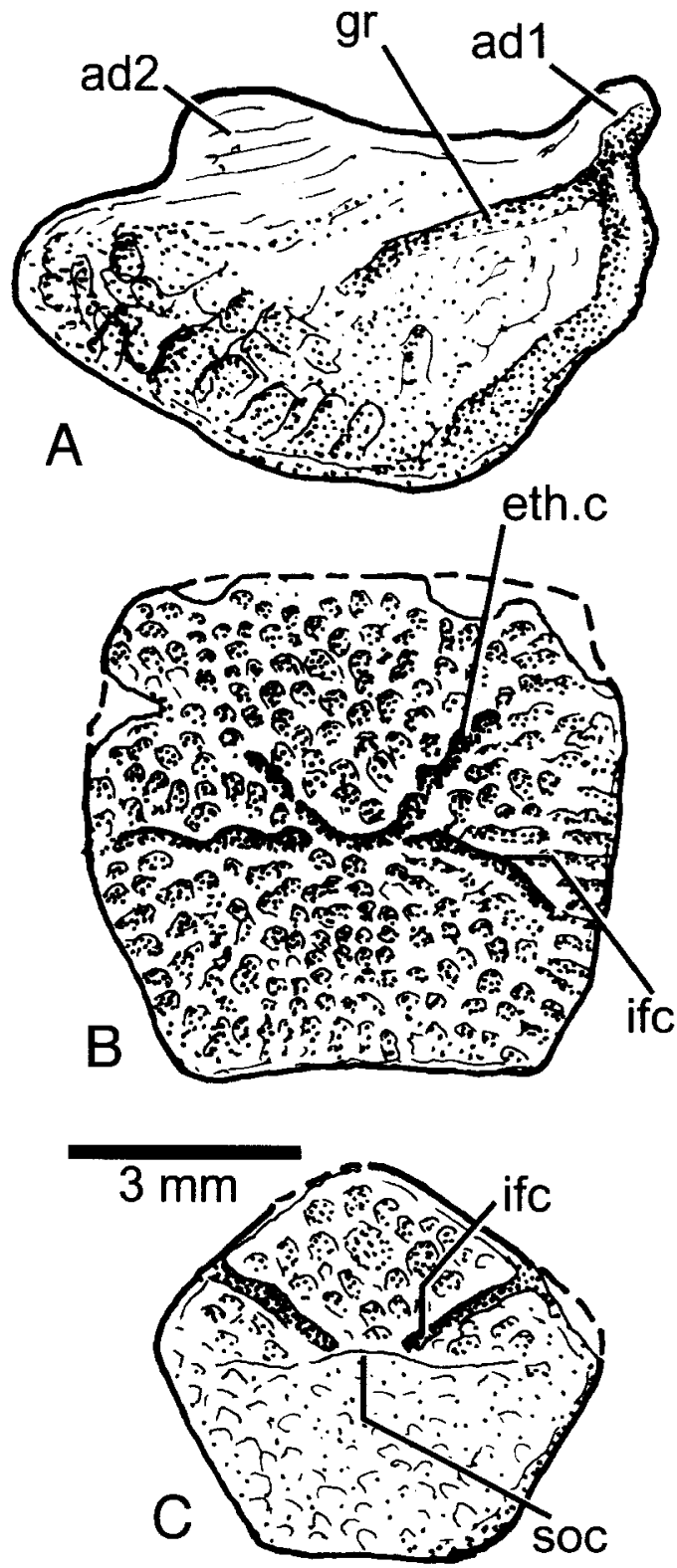

Fig. 10. Camera lucida drawings of skull bones of Bothriolepis perija $\mathrm{n}$. sp. (A, B) and Venezuelepis mingui $\mathrm{n}$. gen. and n. sp. (C). A. Right SO plate (MBLUZ P-229A). B. PrM plate (MBLUZ P-274B). C. PrM plate (MBLUZ P-137B).

other species. Estimated lengths of the proximal and distal segments $(28,18 \mathrm{~mm})$ compare well with fin proportions for $B$. canadensis, in which the distal segment is about $64 \%$ the length of the proximal segment (Stensiö 1948: 361). When folded back against the body armour, the fin would have reached slightly past the posterior end of the subanal laminae of the PVL plates, and thus had similar length to that of other species (e.g., Stensiö 1948: figs 167, 168; pls. 16, 17).

Comparisons: The studied material of $\mathrm{Bo}^{-}$ thriolepis perija $\mathrm{n}$. sp. is small compared to some other species, and insufficient for comprehensive comparisons. Here we comment on three issues: how the Venezuelan species can be distinguished from Bothriolepis canadensis (exhaustively described by Stensiö 1948); whether significant similarities are indicated with Bothriolepis species described from elsewhere in Gondwana (Werdelin \& Long 1986, Young 1988a, Long et al. 1997, Johanson 1998, Johanson \& Young 1999); and whether there are significant similarities or differences to the Colombian Bothriolepis remains (Janvier \& Villarroel 2000).

Bothriolepis perija n. sp. can be distinguished from $B$. canadensis by such features as the sensory grooves on the PrM, the shape and attachment of the SM, the probably more elongate $\mathrm{Nu}$, and broader AMD and PMD plates, the higher $\mathrm{MxL}$ with an obtuse angle between laminae, and possibly the more elongate ventral armour as shown by the holotype. Suggested similarities to other Gondwanan species include the possible trilobate preorbital recess of the skull, the possibly primitive sensory groove arrangement on the anterior part of the skull, the shape of the SM and nature of its attachment to the La plate, and the vascular grooves on the inner surface of the AMD. The Bothriolepis material from Colombia may belong to two species, which have different types of preorbital recess (neither trilobate), and the attachment areas for the SM on the La plate are differently developed to $B$. perija. In addition, the AMD may have been broader, and the $\mathrm{MxL}$ is more similar to that of $B$. canadensis, with more elongate proportions, and a lower angle between laminae.

\section{Suborder Asterolepidoidei Miles, 1968}

\section{Venezuelepis n. gen.}

Type species: Venezuelepis antarctica (Young, 1988a)

Diagnosis: An asterolepid antiarch in which the anterior median dorsal (AMD) plate carries a median ventral ridge and groove, and has a narrow or pointed anterior margin, with posteriorly placed lateral corners such that the anterior division comprises some $70 \%$ or more of total plate. The PDL plate overlaps the AMD along its posterolateral margin. Possibly the PrM plate of the skull has a pointed anterior margin, the ADL plate overlaps the AMD anteriorly, and the ADL and AVL plates may extensively overlap the anterior margins of the PL plate. The first dorsal and ventral central plates of the pectoral fin were probably short and broad, and the M12 plate had a blunt and broad rather than pointed anterior end. 
Remarks: This new taxon is described from two widely separated localities (Antarctica, Venezuela). Its assignment to the Asterolepidoidei is based on the association at both localities of elements of the skull and pectoral fin, which display characteristic asterolepid features. The AMD plates from both localities are highly distinctive, and sufficient to separate Venezuelepis n. g. from all previously known asterolepids. The remarkably long anterior division of this AMD is most closely approached by the sinolepid Xichonolepis, but in that form the AMD is much more elongate, has a broader anterior margin, overlaps the PDL along its posterolateral margin, and has a well-developed anteroventral pit and anterolateral ridge on the visceral surface. A very narrow or pointed anterior margin is seen in the AMD of some species of the genus Remigolepis Stensiö (e.g., R. acuta from the Late De- vonian of East Greenland), but this genus has a proportionately much longer posterior division, and lacks the ventral ridge and groove on the visceral surface. The AMD of Pambulaspis Young from southeastern Australia is readily distinguished by the broad anterior margin to the AMD, the anterior position of the lateral corners, and an anterior division which is only slightly longer than the posterior.

\section{Venezuelepis antarctica (Young, 1988a)}

Figs $11 \mathrm{E}-\mathrm{G}, 12 \mathrm{C}, \mathrm{D}$

\footnotetext{
Synonyms:

1988a Pambulaspis antarctica - Young: 107-109, fig. 64, pl. 15 , fig. 9

1989 Pambulaspis antarctica - Young: table 1, p. 51

1991 Pambulaspis antarcticus - Young: 549

2000 "provisionally assigned to Pambulaspis" - Young, Moody \& Casas: fig. $2 \mathrm{C}$
}

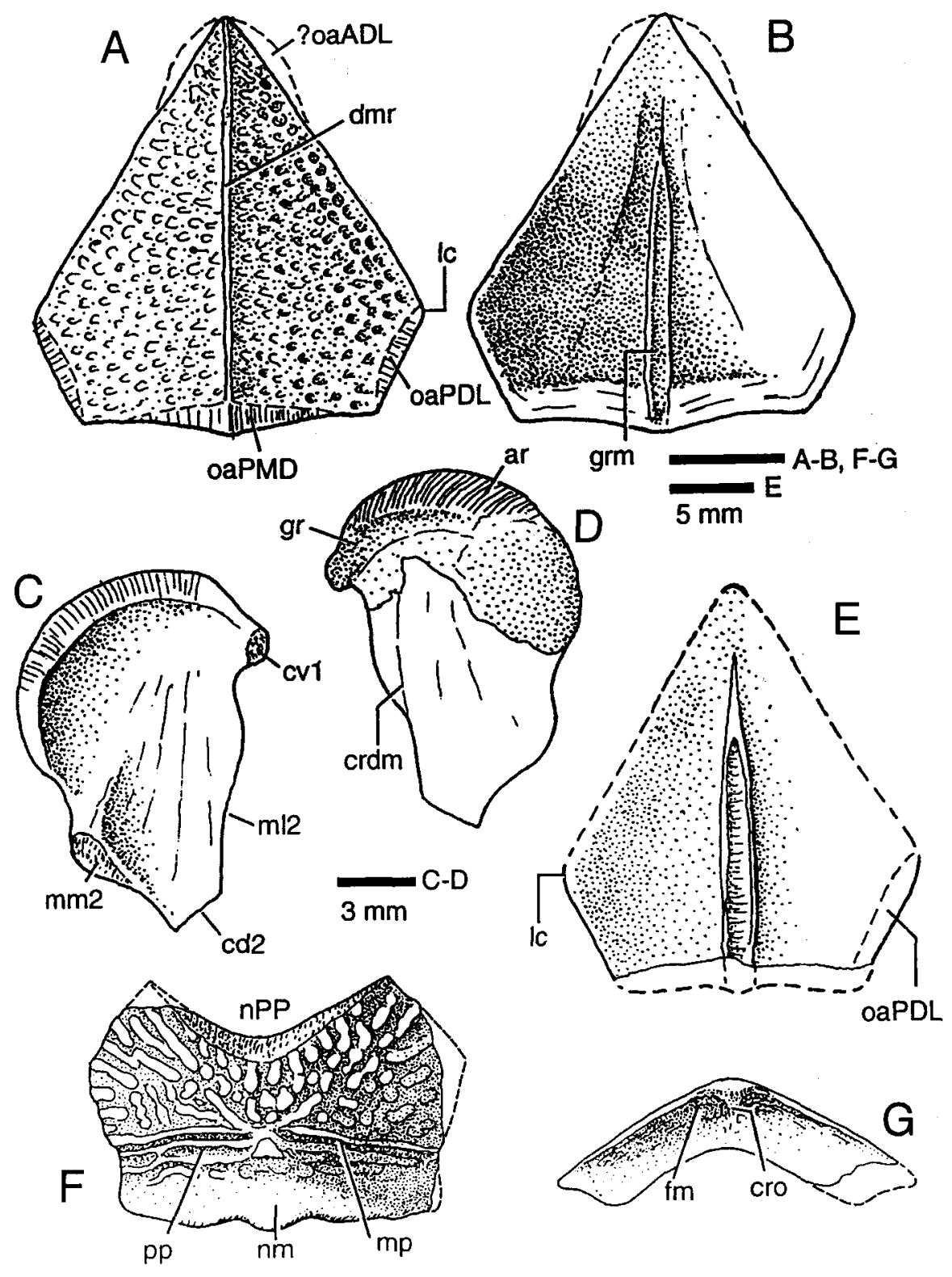

Fig. 11. Venezuelepis n. gen. A-D. V. mingui n. sp., Sierra de Perijá, Venezuela. E-G. $V$. antarctica (Young 1988a), Transantarctic Mountains, southern Victoria Land, Antarctica. A, B. Restoration of AMD plate in dorsal and ventral view, based on the holotype (MBLUZ P247), with information from other material. C, D. Left $\mathrm{Cd} 1$ plate in external and internal view (partly restored). E. Restoration of AMD plate in ventral view (modified from Young 1988a: fig. 64C). F, G. Nu plate in dorsal and posterior views (modified from Young 1988a: fig. $64 \mathrm{~A}-\mathrm{B}$ ). 
Holotype: CPC 26402-03, associated Nu and AMD plates preserved as impressions.

Referred specimens: WAM 90.2.6, an incomplete Nu; WAM 94.6.1, small median element (?ridge scale), WAM 94. 6. 3, possible PMD; WAM 94. 6. 4, possible AMD, all preserved as external impressions.

Locality and horizon: The holotype comes from the Transantarctic Mountains, at locality 24 of Young (1988a), in unit 62 of section A4 of Askin et al. (1971). The other material comes from "Fish hotel site B", at Fault Bluff in the Cook Mountains (McLaughlin \& Long 1994).

Diagnosis: A species of Venezuelepis in which the AMD is arched, with laminae meeting at an angle of about 100 degrees in the midline. The plate has a median dorsal ridge, and a narrow rounded anterior margin.

Remarks: The AMD is the only bone known in both species assigned to the genus, and in $V$. mingui $\mathrm{n}$. sp. it has a pointed anterior margin, and was apparently a much flatter plate. The morphology of the AMD is quite different to that of Pambulaspis, to which the associated $\mathrm{Nu}$ plate of the holotype was originally assigned, as a new species Pambulaspis antarctica (Young 1988a: fig. 64).

Description: The holotype comprises an associated Nu plate and AMD preserved as impressions of the external and internal surfaces respectively (Fig. 12C, D). Originally (Young 1988a: 109), it was suggested that the two impressions did not belong to the same taxon, even though they are close together, and the only impressions on the small sandstone sample. One was identified as a "possible" AMD plate because "the ventral ridge and depression have exactly the form of the median process and pit developed on the inner surface of the AMD and PMD plates in antiarchs" (Young 1988a: 109). The absence of contact faces on the inner surface indicated that it was "not a PMD, which in all antiarchs where known overlaps adjacent bones". Small parts of the external surface along the posterolateral margins show narrow overlap areas, which were compared with the overlap onto the AMD by the PDL plate (oaPDL, Fig. 11E) in the asterolepids Pambulaspis, Pterichthyodes, and Sherbonaspis. The associated $\mathrm{Nu}$ plate was provisionally referred to the genus Pambulaspis Young, 1983, but Young (1988a: $108)$ noted that "if the interpretation ... of the associated element as a conspecific AMD is confirmed with new material, then assignment to the genus Pambulaspis would require reconsideration."

The striking resemblance in shape to the triangular bone described below from the Venezuelan fauna, and the median ventral ridge and groove in both specimens, provides good evidence that they are closely related (compare Fig. 12A to C, $12 \mathrm{~B}$ to $\mathrm{D}$ ). The associated $\mathrm{Nu}$ has characters diagnostic for an asterolepidoid antiarch, whilst the Venezuelan specimen is associated with asterolepid pectoral fin bones. In both assemblages these were the only diagnostic antiarch bones which could not be referred to the much more common Bothriolepis.

The new evidence provided by the Venezuelan specimen supports the interpretation of CPC 26403 as an originally symmetrical plate, and therefore an unpaired bone in the armour. The completely preserved anterolateral margins meeting at a point in the holotype of Venezuelepis mingui n. sp. permit a more reliable reconstruction of the shape of the incomplete anterolateral margins in the Antarctic specimen (Fig. 11E). The form of the median ventral ridge, and its close comparison to the median ventral ridge, process, and groove typical of the visceral surface of antiarch median dorsal plates, is also confirmed. Other aspects of the morphology of the AMD, which are included in the generic diagnosis, are discussed below in the description of the new Venezuelan species.

The associated Nu plate of $V$. antarctica resembles that of Pambulaspis cobandrahensis Young 1983 , except for a slightly greater breadth across the lateral corners (Young 1988a: 108). The shape of the postpineal notch (nPP), the absence of orbital facets, and the short broad form, clearly indicate asterolepidoid affinities for this plate (Fig. 11F, G). The "asterolepid" contact between the PP and La plates of the skull is also seen in various yunnanolepid and sinolepid antiarchs, so is likely to be primitive. There is no clear oblique sensory groove, but some lineation in the ornament in the appropriate position. The middle pitline $(\mathrm{mp})$ forms a distinctive transverse groove, with a less obvious posterior pitline (pp). The endolymphatic openings cannot be seen. The development and position of these grooves at the edge of the obtected nuchal area $(\mathrm{nm})$ is closely similar to that described for Pambulaspis by Young (1983: fig. 3A). The obtected nuchal area is normally developed, and the posterior view shows shallow levator fossae $(\mathrm{fm})$ separated by a median ridge (cro). The bone has a $\mathrm{B} / \mathrm{L}$ index of 149 , and the two sides meet at a mid- 


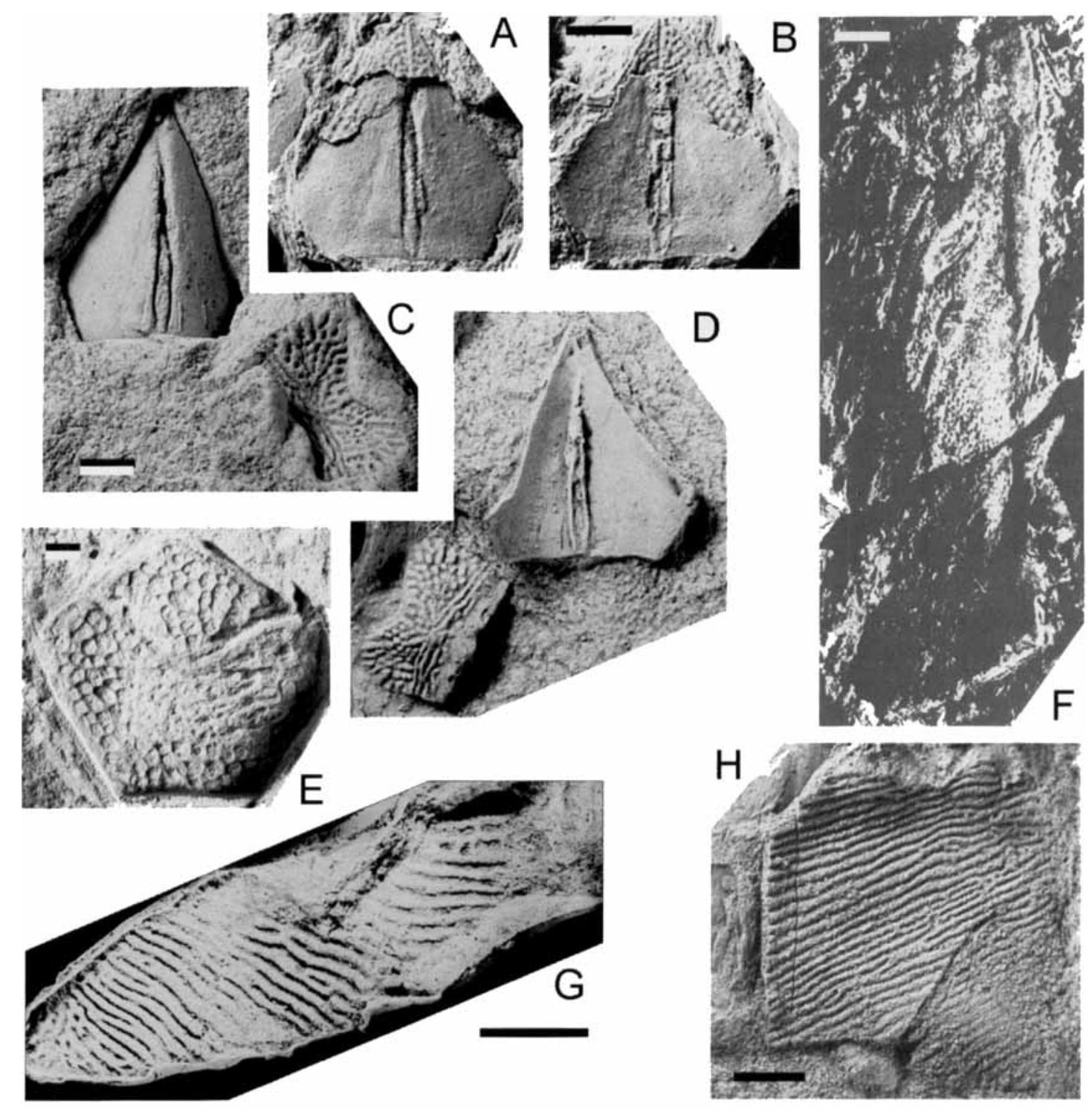

Fig. 12. A, B, E. Venezuelepis mingui n. gen. and n. sp., Sierra de Perijá, Venezuela. A, B. holotype AMD plate in part and counterpart (MBLUZ P-247, $\times 1.8)$. E. Possible PrM plate, external view (MBLUZ P-137, $\times 5$ ). C, D. Venezuelepis antarctica (Young 1988a), southern Victoria Land, Antarctica. Holotype (CPC 26403, 26404, ×1.5), associated Nu and AMD plates, shown as an impression $(\mathbf{C})$ and a whitened latex cast $(\mathbf{D})$. F. ?Ptyctodontid gen. et sp. indet., possible AL plate (MBLUZ P-1387, $\times 0.75$ ). G, H. Phyllolepid gen. et sp. indet. G. Possible fragmentary external impression of a right PVL plate (MBLUZ P-129, $\times 1.5$ ). H. External impression of a right AVL plate (MBLUZ P-130, $\times 1$ ). All specimens except $F$ whitened with ammonium chloride. Scale bar $=5 \mathrm{~mm}$ for $A-D ; 1 \mathrm{~mm}$ for $E ; 10 \mathrm{~mm}$ for $F-H$.

line angle of about $125^{\circ}$, which can be assumed to be a specific difference with $V$. mingui $\mathrm{n}$. sp., judging by the much flatter AMD plate of that species. In the absence of a $\mathrm{Nu}$ plate in the Venezuelan material the other features of this specimen are assumed for the present to be generic characteristics.

Provisionally referred to $V$. antarctica are several incomplete antiarch plates from a new Antarctic locality collected by Dr John Long, which show characters indicating that they do not belong to Bothriolepis. The $\mathrm{Nu}$ plate (WAM90.2.6) is much less complete than the holotype, but is similar in size (estimated B $10 \mathrm{~mm}$ ) and ornament pattern. A transverse groove (middle or posterior pitline) is clearly seen on the left side, even though most of the surface of the obtected nuchal area is broken away. The orbital margin is very incomplete, and the right lateral margin shows only the lateral corner. A distinct linear ridge and associated groove in the ornament on the right side suggest that there was an oblique sensory line. In the holotype the same linear ridge is evident on the left side, but indistinct on the right, and persistent grooves are not developed. Similar lineations in the ornament were noted in a $\mathrm{Nu}$ plate provisionally referred to Asterolepis? by Janvier \& Villarroel (2000: 744). Specimen WAM94.6.4 is an impression with similar tuberculate orna- 
ment showing two laminae meeting at about $110^{\circ}$ on either side of a strong crest, complete at one end ( $\mathrm{L} 30 \mathrm{~mm}$ ). Radiation in the ornament suggests a symmetrical bone (AMD or PMD), with one lamina very incomplete, but the ornament lineations seem slightly different on each side of the crest, suggesting also perhaps a left PDL plate with a low ornamented lateral lamina. Short oblique ridges on either side of the crest remind of the anterolateral ridges which may develop in antiarchs from the tergal angle of the AMD or the posterior end of the PMD (e.g., Young 1983: fig. 4E, 1988a: pl. 3, fig. 8). This plate is too incomplete for determination, but similar ornament to both $\mathrm{Nu}$ plates suggests that it belonged to the trunk armour of $V$. antarctica. WAM94.6.3 is another plate bearing a slight crest or keel about $22 \mathrm{~mm}$ long, which could be a PMD lacking almost all of its right lamina. Preserved ornament near the margins is similar to that in the previous specimens. Finally WAM94. 6.1 is a small apparently symmetrical bone (L, B, 11, $10 \mathrm{~mm}$ ), again with similar tuberculate ornament, lateral corners and a pointed anterior (?) margin. The coarse tubercles show it is not a very small AMD, so it could be an enlarged median scale or scute. Apart from the $\mathrm{Nu}$ plate, none of these remains from Mt Cook can be confidently included with $V$. antarctica.

\section{Venezuelepis mingui n. sp.}

Figs 9G, H, 10C, 11A-D, 12A, B, E

Synonyms:

1992 "un nuevo género afin a Bothriolepis" - Casas et al.: 6. 1997 Venezuelepis perijá (n. nud.) - Berry, Casas, Moody \& Young: 128

2000 "a new asterolepid antiarch" - Young, Moody \& Casas: 758 , fig. $2 \mathrm{D}$

Etymology: From the word "mingui" (a large arrowhead) of the Macoa language, a tribal group of the Yukpa Indians living between la Villa del Rosario and Machiques (information provided by Dr Angel Viloria, Caracas, from a vocabulary compiled by ethnographer Theodoor de Booy in 1918). This is an allusion to the pointed shape of the holotype.

Holotype: MBLUZ P-247, an AMD plate preserved in part and counterpart.

Referred specimens: MBLUZ P-137B, a possible PrM plate from the skull; P-243, a Cd1 plate from the pectoral fin; P-200, a possible incomplete PL plate.

Locality and horizon: All from locality 139, Caño Colorado Sur, in the upper member of the Campo Chico Formation (Fig. 1E)
Diagnosis: A species of Venezuelepis in which the AMD is relatively flat, with a reduced median dorsal ridge, and an ornament of reticulate or vermiculate ridges. The anterior margin is reduced to a point.

Remarks: These features are observed differences to the AMD of the Antarctic species just described, which has a slightly broader anterior margin, and apparently a more arched armour. The ornament on that AMD was evidently more tuberculate than on the associated $\mathrm{Nu}$ (Young 1988a: 109), which is probably another specific difference.

Description: The holotype is an almost complete plate ( $\mathrm{L} 17.5 \mathrm{~mm} ; \mathrm{B} / \mathrm{L}$ 94) preserved in part and counterpart (Fig. 12A, B). It is symmetrical, with a pointed anterior and broad posterior margin, and distinct lateral corners (lc, Fig. 11), which are posteriorly placed, such that the anterior division of the plate comprises about $70 \%$ of total length. The visceral surface is crossed by a median ventral ridge, preserved as an impression on the counterpart which shows an elongate median depression (grm). Small sections of the ornament are exposed, showing vermiculate ridges anteriorly on either side of a low median dorsal ridge ( $\mathrm{dmr}$ ), tending to a more regular reticulation along the lateral margins. A small smooth area on the right side of the counterpart (Fig. 12A) may be part of an overlap area (oaPDL).

The clear resemblance of the visceral surface to the triangular impression from the Antarctic described by Young (1988a: fig. 64) has been discussed. The evidence of P-247 indicates that the Antarctic specimen was a symmetrical plate, and therefore must be an unpaired bone in the armour. The median ventral ridge and groove are similarly developed in both specimens. The groove could be interpreted as a much elongated anterior ventral pit (Young 1988a: fig. 64), or the pit could have been reduced and lost with narrowing of the anterior margin, with the remaining depression being equivalent to the median groove developed in the posterior part of the visceral surface in antiarchs.

The well-preserved anterolateral margins of MBLUZ P-247 meet at a point (Fig. 12A, B). Other margins are sufficiently preserved to show that there are no contact faces on the internal surface. On this evidence, the specimen could not be interpreted as a PMD plate, which in all known antiarchs overlaps adjacent bones. The external surface is not exposed along the poster- 


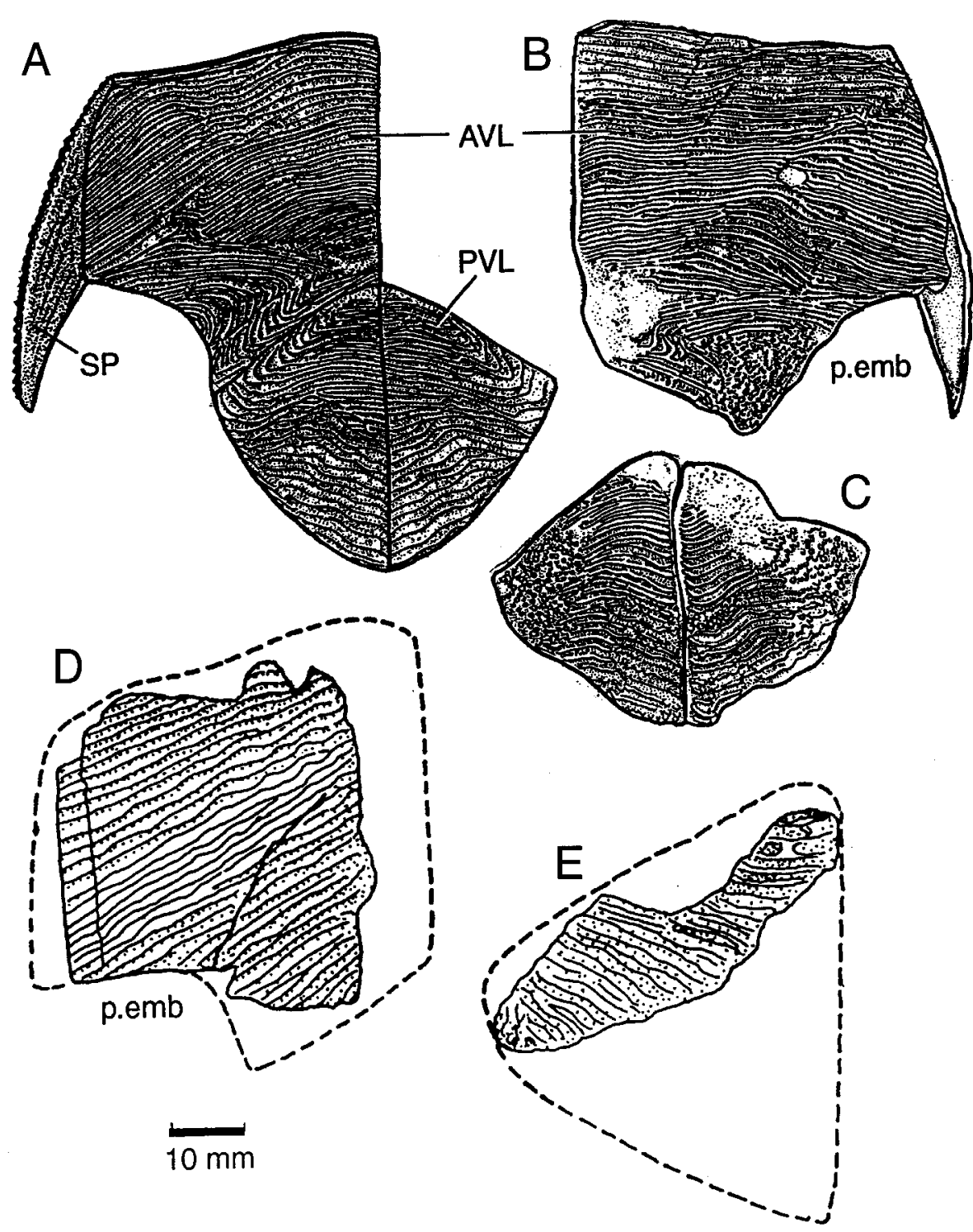

Fig. 13. A. Partial restoration of ventral trunk armour (right IL, SP, AVL, left and right PVL) of Placolepis budawangensis (after Ritchie 1984: fig. 8C). B, C. Left AVL and SP, and both PVLs (C) of the holotype of Austrophyllolepis ritchiei (after Long 1984: fig. 5). D. Possible interpretation of MBLUZ P130 (Fig. $12 \mathrm{H}$ ) as part of a right AVL. E. Possible interpretation of MBLUZ P-129 (Fig. 12G) as part of a right PVL.

ior margin, so overlap relationship to the plate behind (PMD) is uncertain. However, a slightly elevated area inside the posterior margin on the inner surface (Fig. 11B, 12B) can be compared with isolated AMD plates of the sinolepid antiarchs Grenfellaspis and Xichonolepis (Ritchie et al. 1992: figs 6B, E, 26A). In these taxa the PMD overlaps the AMD in the middle part, with a butt joint laterally. A similar overlap area has been assumed in the reconstruction (oaPMD, Fig. 11A). Other evidence comes from a similar pointed AMD from Tatong (Victoria, Australia) that shows this overlap area (Dr John Long, pers. comm.). The anterolateral margins of MBLUZ P-247 also show no sign of an overlap or contact face for the ADL. The AMD of all other described antiarchs overlaps the ADL along their common suture. However the Tatong AMD just mentioned (to be described elsewhere), shows a small anteriorly placed external overlap, so this has been assumed in the recon- struction (?oaADL, Fig. 11A). A posterior nonoverlapping suture between the AMD and the ADL is seen in sinolepids (Ritchie et al. 1992: figs 8,26 ). Judging by the condition in very small specimens of Bothriolepis (Young 1988a: figs 21-22), there is an ontogenetic argument that having overlap restricted to the anterior end of the ADL-AMD suture may be primitive within the antiarchs, or at least within some antiarch subgroups. In most placoderm groups the MD overlaps both dorsolateral plates, so this is probably the primitive placoderm condition, in antiarchs retained by Asterolepis. The "remigolepid" overlap type, where the posterior section of the PDL overlaps onto the AMD, is also seen in some yunnanolepids (e.g., Zhang 1978, Zhu 1996), and asterolepids (e.g., Byssacanthus, Stegolepis). In Pambulaspis the PDL overlaps the AMD along its entire junction, as is also the normal case with the MxL plate of Bothriolepis. However, overlap of the AMD by the ADL, as 
suggested here for Venezuelepis, has not previously been described in antiarchs, although it occurs in a new antiarch taxon from the Famennian of eastern Australia (Young, unpublished). This may be a unique condition for placoderms.

Also referred to $V$. mingui $\mathrm{n}$. sp. are a few isolated bones which on shape and ornament clearly belong to antiarchs, but are different from corresponding bones of Bothriolepis. Most distinctive is a small unpaired bone (MBLUZ P137B; L $7.5 \mathrm{~mm}$, B $8.5 \mathrm{~mm}$ ) crossed by sensory grooves, which can be interpreted as a PrM from the skull (Fig. 12E). It does not correspond to any part of the dermal skeleton of Bothriolepis, and it has a different shape to the PrM in other antiarchs, with distinct lateral angles, and a pointed anterior margin. As oriented in Figure $10 \mathrm{C}$ the sensory groove passes off the anterolateral margin, which permits comparison with the PrM of Asterolepis, which may also have a distinct lateral corner behind the sensory groove (e.g., Karatajute-Talimaa 1963: fig. 22). The specimen provisionally identified by Young \& Gorter (1981: fig. 12) as a PrM of Sherbonaspis also

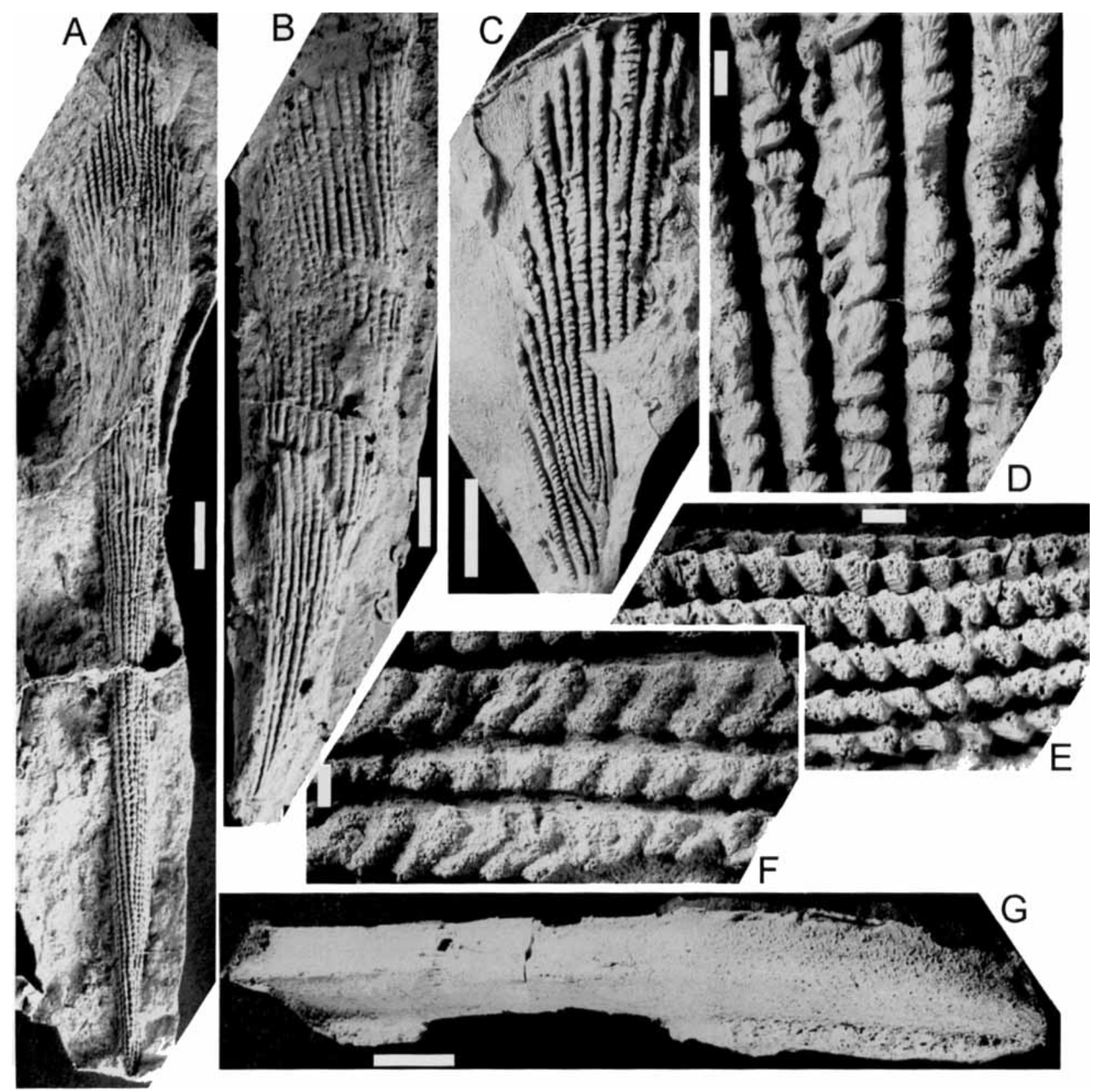

Fig. 14. A-F. ?Antarctilamnid chondrichthyan spines. A. MBLUZ P-7, anterior view $(\times 1)$. B. MBLUZ P-5, right lateral view $(\times 1)$. C. MB. f.7630, anterior view $(\times 1.5)$. D. Detail of $C(\times 3)$. E. Detail of MBLUZ P-7, left side, about $30 \mathrm{~mm}$ from spine tip ( $\times 3)$. F. Ornament detail of MBLUZ P-6 $(\times 3)$. G. Machaeracanthus sp., incomplete fin spine, dorsal view, proximal end to left (MBLUZ P-133, $\times 1.3$ ). All photographs of latex casts whitened with ammonium chloride. Scale bar $=10 \mathrm{~mm}$ for $\mathrm{A}-\mathrm{C}$, G; $2 \mathrm{~mm}$ for $\mathrm{D}-\mathrm{F}$. 
has the main sensory groove passing anterolaterally, but with a more extensive anterior part of the plate, which differs from this specimen in having a distinct depression, and a transverse anterior margin. In MBLUZ P-137B the sensory canal system is developed as median and lateral divisions (soc, ifc), consistent with its interpretation as a PrM. If correctly oriented, and complete as assumed here, the pointed anterior margin of MBLUZ P-137B would be unique amongst known antiarchs, implying also a distinctive shape to the La plate of the skull (not identified in the material).

The only other elements assigned with any confidence to Venezuelepis are some disarticulated bones of the pectoral fin. The short and broad first dorsal or ventral central plates of the proximal fin segment can be readily identified, and distinguished from those of Bothriolepis. MBLUZ P-243 is a probable Cd1 preserved in part and counterpart (Fig. 9G). This was the first specimen found which indicated a second antiarch in the assemblage. It is short and broad (L $13 \mathrm{~mm}$; $\mathrm{B} 10 \mathrm{~mm}$ ) and considerably shorter in proportion (L/B 130), than some other asterolepids, e.g., Asterolepis (Stensiö, 1931), Pterichthyodes (Hemmings, 1978) or Sherbonaspis Young \& Gorter (1981). The external surface is only exposed at the proximal end, showing a smooth groove (gr, Fig. 11C-D) behind the articular area (ar), which extends to a distinct lateral process terminating in a small contact face. This must have been the contact for the Cv1, and the adjacent Ml2 plate must have had a blunt and broad anterior end, less pointed than in other forms, as occurs for example in Asterolepis ornata (e.g., Gross 1931: pl. 6, fig. 1). The inner surface preserves the opposite contact for the $\mathrm{Mm} 2$, which again differs somewhat from previous descriptions in its more distal position. MBLUZ P-138 is a smaller example of the same bone $(\mathrm{L} 8 \mathrm{~mm}$ ), with similar proportions (L/B 133). Both examples show an extra margin for the $\mathrm{Cd} 2$, characteristic of the asterolepid fin pattern, but lost in Bothriolepis. Other probable pectoral fin remains are listed in the Appendix, but have not been prepared or studied. An articulated example is needed to establish the morphology of the other component bones of the fin in Venezuelepis.

A few additional specimens are doubtfully included in this new taxon. MBLUZ P-200B is a very incomplete plate with antiarch ornament which shows two well developed adjacent overlap areas disposed around a distinct angle on the ornamented part (Fig. 9H). The overlap areas differ in shape so this must be a lateral margin. The antiarch MV plate is overlapped by all surrounding bones, but this is quite different in shape to the MV of Bothriolepis (Fig. 9C). The only other plate of Bothriolepis overlapped by adjacent bones is the anteroventral corner of the MxL, which is again differently developed. By elimination therefore this specimen could belong to Venezuelepis, perhaps representing the broken anterior part of a separate PL plate. As described for Pambulaspis by Young (1983: fig. 7B), the PL has an anterior corner separating overlap areas for the ADL and AVL. Under this interpretation only the anterior end of the bone would be preserved, with overlap areas which are much more extensive than in Pambulaspis.

Other unprepared material, not studied in detail (see Appendix), includes MBLUZ P-115, a possible left ADL plate showing a prominent anterodorsal extension of its dorsal lamina, consistent with the shape of the AMD. MBLUZ P270 was provisionally identified as a possible left PDL, and P-311 as a possible antiarch PL, which if correctly identified could also be referred to Venezuelepis, these plates not occurring in $\mathrm{Bo}$ thriolepis.

Comparisons: The relationship of this poorly known new asterolepidoid taxon is very uncertain. Previously the Antarctic Nu plate was compared with that of Pambulaspis, whilst the posterolateral overlap areas on the associated AMD were compared with the overlap onto the AMD by the PDL in Pambulaspis, Pterichthyodes, and Sherbonaspis. The long anterior division of the AMD is matched by the sinolepid Xichonolepis, and measurements given by Ritchie et al. (1992, table 5) show that it varies between at least $69-83 \%$ the length of the plate. However the AMD of Xichonolepis is much more elongate (B/L index 49-87), with a broader anterior margin, and it overlaps the PDL along its posterolateral margin. There is also a well-developed anteroventral pit, and anterolateral ridge on the visceral surface. A very narrow or pointed anterior margin is seen in the AMD of some species of Remigolepis (e.g., R. acuta from East Greenland). In the recent phylogenetic analysis of Zhu (1996) Asterolepis, Remigolepis, and Pambulaspis were grouped together. Only Pambulaspis has an appreciable anterior margin to the AMD, and on this feature Venezuelepis would be closer to Remigolepis than to Pambulaspis, but there are clear differences in plate proportions. No mea- 
surements are given for the species Remigolepis walkeri described from Canowindra (represented by over 1000 articulated specimens), but it is evident that it had a much longer posterior division, approaching half the length of the plate (Johanson 1997: fig. 2).

The narrow anterior margin on the antiarch AMD was interpreted as the primitive condition in the analysis of Zhang \& Young (1992), because it is also seen in Early Devonian South Chinese taxa like Yunnanolepis, which could be regarded as outgroups to the Euantiarchi. However the evidence of ontogenetic change from a broad to narrow margin in Asterolepis (Upeniece \& Upenieks 1992: fig. 2), suggests that, within asterolepidoids at least, this is a derived feature. Outgroup comparison with groups like arthrodires, petalichthyids, and phyllolepids supports this. Current evidence that the narrow anterior margin evolved separately in several antiarch subgroups confounds any attempt to determine the relationships of a poorly known form like $V e$ nezuelepis. Similarities in the shape and position of the sensory canals on the $\mathrm{Nu}$ of the Antarctic specimen were originally assumed to indicate affinity with Pambulaspis, but until other examples of this bone are found this is difficult to assess. Finally, it is noted that Janvier \& Villarroel (2000: fig. 10) illustrated some large fragmentary bones from Colombia which they assigned to Asterolepis? sp. indet., including a large skull fragment with an incomplete PP apparently showing a short segment of the suture with the left La. This confirms its asterolepidoid affinities. Janvier \& Villarroel (2000) note the possibility of an oblique sensory groove on the $\mathrm{Nu}$ (a bothriolepid character), as was mentioned above in material of Venezuelepis from Antarctica. However we have seen no sign of such large bones with nodose ridged ornament in the Venezuelan collection.

\section{Order Ptyctodontida Gross, 1932}

\section{Ptyctodontid gen. et sp. indet.}

Fig. $12 \mathrm{~F}$

Material: MBLUZ P-1387.

Locality: 150 , a small outcrop $25 \mathrm{~m}$ downstream from the main locality (139) at Caño Colorado Sur, on the opposite side of the anticline in beds thought to represent a similar level (Fig. 1E).

Remarks: The affinities of this plate are very uncertain. It is said to come from a similar hori- zon to locality 139 , but nothing comparable was found in the large collection from the main locality.

Description: This is a moderately sized plate $13 \mathrm{~cm}$ long and $4 \mathrm{~cm}$ wide at one end. It is fairly flat with a raised ridge along the straight longer side ending in a possible articulation or overlap at the wide end. This ridge has a flat smooth surface, but the rest of the plate is covered with closely spaced rows of triangular denticles. A set of concentric broad ridges indicate that the other long margin, which is partly covered, was gently convex. These broad ridges are crossed by about 4-5 denticles in each row, and they all face towards one corner of the plate.

This ornament is rather different from that normally encountered on the outer surface of dermal bones. However triangular denticles arranged in rows all pointing in one direction is a feature of the postbranchial lamina of the AL in some placoderms, and this specimen has a shape reminiscent of the ptyctodontid AL plate, which is high and narrow, with a smooth lateral margin, and denticles facing ventrolaterally. Thus the specimen could be interpreted as a postbranchial part of a left ptyctodontid AL, with the smooth ridge along one side representing the lateral margin, and the remainder of the lateral lamina lost from the plate. The shape as preserved (Fig. 12F) corresponds with the reconstruction of Campbellodus from Gogo (Long 1997: fig. 14), but it is clear that the Venezuelan specimen lacks the large crenulate denticles of that form. Ptyctodontids range from the Early to the Late Devonian, and are known from the Eifelian to the Famennian in North America, Europe and Russia (Denison 1978). Alternatively, MBLUZ P-1387 could be a right interolateral (IL) plate, which also carries the same special ornament, with denticles facing ventrolaterally. In this case the smooth marginal ridge would be the ventral border of the postbranchial lamina, past which the IL folds around onto the ventral surface of the trunk armour, to overlap the anterior edge of the AVL plate. Interpreted as a placoderm IL, the ventral lamina would be lost from the plate.

\section{Order Phyllolepida Stensiö, 1934}

\section{Phyllolepid gen. et sp. indet.}

Figs 12G, H, 13D, E

Synonyms:

1992 "Placa de un Phyllolepidae" - Casas et al.: fig. 11. 
1997 "placas de un Phyllolepido" - Berry, Casas, Moody \& Young: 127

2000 "phyllolepid placoderm" - Young, Moody \& Casas: fig. $2 F$

Material: MBLUZ P-129, P-130

Locality: Rio Socuy Road section, locality 118. Both specimens occurred as float. P-129 was found on the morning of 7 July 1992 by Dr Angel Luis Viloria (his first fossil fish), a few minutes after parking the vehicle near the top of the section, about $50 \mathrm{~m}$ down from the faulted contact with the Caño del Oeste Formation (Fig. 1D). MBLUZ P-130 was found the following day (G.C.Y.), as float on the outer side of the road about $45 \mathrm{~m}$ down the road from the first specimen, and in similar lithology, presumably a sandstone lens excavated in road construction. Other blocks of the same material could be seen in scree downslope beneath the road. The faulted contact is interpreted to be between the Caño del Oeste Formation and the upper part of the lower Campo Chico Formation (C. Berry, pers. comm. 29/6/01). These remains are therefore presumed to come from the upper part of the lower member of the Campo Chico Formation.

Remarks: These incomplete plate impressions display the distinctive ridged ornament of the order Phyllolepida, and one shows some special features (anastomosing ridges, and ridges retaining signs of tuberculation), which have so far only been recorded in species of the Victorian genus Austrophyllolepis Long, 1984. Neither bone can be definitely determined because of incomplete margins. They occur in similar sandstone lithology, and are assumed to belong to one taxon, which is left in open nomenclature until more information is available.

Description: MBLUZ P-130 is the larger of the two impressions ( 47 by $42 \mathrm{~mm}$ across). Most of the margins are broken, with the possible exception of the posterolateral edge as oriented in Fig. 13D. The ridged ornament is slightly coarser than in MBLUZ P-129, and generally more regular, but not as well preserved (Fig. 12G, H). This impression is clearly from a plate of considerable size. There is no indication of a change in orientation of the ornament, nor any sign of sensory grooves, so it is most unlikely to have come from the two large dorsal bones of the armour ( $\mathrm{Nu}$ and $\mathrm{MD}$ ), which have concentric ridges. It can be assumed that the ornament was transversely oriented, and the possibly complete margin suggests the pectoral embayment of a right AVL plate (p.emb, Fig. 13D). The ornament may be concentric around this margin in some phyllolepids (e.g., Placolepis, Fig. 13A). In Austrophyllolepis the posterolateral part of the plate may be tuberculated (Fig. 13B), but the anterior ornament of the pectoral embayment meets the margin at a low angle, essentially as restored for MBLUZ P-130 (Fig. 13D), and as seen in other species (e.g., Phyllolepis woodwardi, Ph. nielseni; Stensiö 1939: fig. 2, pl. 3, fig. 3).

The smaller impression (MBLUZ P-129; $5 \mathrm{~cm}$ $\times 20 \mathrm{~mm}$ maximum width), is an elongate fragment with no natural margins. It also displays typical phyllolepid ornament, but with some special features (Fig. 12G). The slightly sinuous ridges and narrow grooves cross the impression obliquely, and the coarseness of the ornament suggests that it is a diagonal slice from a plate of similar size to the previous specimen. The ridges change direction along the fragment, and some of the ridges interconnect, with suggestions of coalesced tubercles, features not seen in the previous specimen. It can be assumed that the ridges had a general concentric and predominantly transverse arrangement, as is normally the case in phyllolepids (Fig. 13A-C).

The specimen is too elongate to be one of the small plates of the head, and it lacks sensory grooves, so is unlikely to have come from the $\mathrm{Nu}$ plate, the largest bone of the skull, which is crossed by up to four pairs of radiating sensory grooves. Nor does it fit the PNu, which also has a sensory groove. Both the Nu and the MD plate of the trunk armour normally display angular inflections of the ridges, which this specimen does not show. It could be from the anterior part of an $\mathrm{MD}$, or from an AL, AVL or PVL plate, the only other large bones in the phyllolepid dermal skeleton which lack sensory grooves. The ornament ridges seems coarser and more closely spaced than in Ph. woodwardi, Placolepis, or new material from the south coast of NSW (Young in press), and at both ends are small areas with anastomosing connections between ridges, and some tuberculation. These features may be compared to material of the Victorian species of Austrophyllolepis described by Long (1984). In A. ritchiei (e.g., NMV P160723), anastomosing ridges, and tubercles aligned in rows, or coalesced into ridges, may occur on the anterior parts of the $\mathrm{Nu}$, the margins of the $\mathrm{PNu}$, and posterolateral parts of the AVL and PVL plates (Long 1984: figs 4-5, 9-10, 11B). Such ornament is almost unknown in other described phyllolepids, in which the ornament ridges are typically continuous and smooth (one 
PVL from Greenland shows an atypical peripheral zone of tubercles; Stensiö 1934: pl. 16, fig. 2). It is suggested therefore that this fragment could come from one of the ventral plates of a phyllolepid with ornament like Austrophyllolepis (Fig. 13B, C). Ornament orientation is consistent with it being from the anterior part of a right PVL plate, as in Figure 13E.

\section{Order indet.}

Material: MBLUZ P-131, 132

Locality: Rio Socuy Road, new roadcut section, Locality 118 (Fig. 1D).

Remarks: These are most likely fragmentary placoderm impressions, but their affinities are very uncertain.

Description: MBLUZ P-131 is a poorly preserved ridged impression of $15 \mathrm{~mm}$ maximum width and about $55 \mathrm{~mm}$ long, with a stepped down smooth surface about $15 \mathrm{~mm}$ long at one end, possibly an overlap area. Specimen P-132 comprises two poorly preserved associated impressions, one of an elongate plate $(45 \times 12 \mathrm{~mm})$ which is $\sim 2.5 \mathrm{~mm}$ thick, with a flat to slightly convex inner surface with rounded edges (apparently natural margins). The external surface shows very indistinct longitudinal ridges. One end is pointed, the other has a distinct stepped margin onto a smooth overlap area about $8 \mathrm{~mm}$ across. Possibly this is a similar element to MBLUZ P-131. The associated impression is about $30 \mathrm{~mm}$ long, with one end narrowing to a blunt point, and the other a broken edge about $18 \mathrm{~mm}$ across. It is deeply concave about a longitudinal axis, but is unlikely to be the inside of a spine because it is apparently asymmetrical. A small preserved area of the external surface is smooth, and may be another overlap area.

\section{Class Chondrichthyes Huxley, 1880}

Subclass Elasmobranchii Bonaparte, 1838 Family Antarctilamnidae nov.

\section{?Antarctilamnid gen. et sp. indet.}

Figs $14 \mathrm{~A}-\mathrm{F}, 15$

\section{Synonyms:}

1990 "espina de pez elasmobranquio afin con el género Antarctilamna" - Casas et al.: fig. 13.

1992 "Espina de Antarctilamna sp." - Casas et al.: figs 9-10.

1997 "espinas identificado como Antarctilamna" - Berry, Casas, Moody \& Young: 127 , fig. 5 .

2000 "antarctilamnid sharks" - Young, Moody \& Casas: 759

Material: MBLUZ P-5-7; 134-135, 904, 1113, 1116, 1347
Localities: Rio Socuy Road, new roadcut section, locality 118 (MBLUZ P-5, 6, 7, 135, 904, 1113, 1116, 1347, MB. f.7630), and locality 121 (MBLUZ P-134). The first spine found (MBLUZ P-5) occurred in situ at plant locality 8 , where the main sandstone crops out in the bed of the road (Berry et al. 1993: 33), which is about $300 \mathrm{~m}$ up the new road from its junction with the old road (Fig. 1D). This is locality $\mathrm{E}$ of Casas et al. (1990). MB. f.7630, also found in situ, was about $50 \mathrm{~m}$ higher in the section (locality G of Casas et al. 1990; locality 10 of Berry et al. 1993). MBLUZ P-7 was collected on December 30, 1990 from a float sample at the side of the road in this vicinity.

Remarks: These spines approximate to ctenacanth spines according to Maisey's (1981) definition of the genus Ctenacanthus (spines gradually tapering and recurved posteriorly; anterior face narrow and rounded; ornament of closely spaced longitudinal ribs with a "pectinate" ornament). Young (1982) noted the absence of an area of insertion as a distinctive feature of the ctenacanth-like spines of the shark Antarctilamna prisca. However the spine described as Antarctilamna seriponensis from the Bolivian Early Devonian has a well developed inserted portion (Gagnier et al. 1988: fig.11B), and also differs from the type species in its shorter more triangular shape with straight anterior and posterior margins, and probably more rounded cross section. This new material includes spines apparently both with and without an insertion area, which may belong to the same taxon. All studied specimens are impressions, which do not show such features as the shape of the posterior face, the presence of a proximal median posterior ridge, and of denticles along the posterolateral margins. In the absence of more extensive material these are regarded as ctenacanth-like spines, provisionally referred to the family Antarctilamnidae.

Description: The material includes a range of fin-spine impressions up to at least $160 \mathrm{~mm}$ long. This description is based on two fairly complete impressions (MBLUZ P-5, 7), and four more fragmentary examples (MBLUZ P-6, 134-135, MB. f.7630). They indicate spines of two different types. Other specimens listed in the Appendix are provisionally referred to this taxon on field identification.

One spine type is represented by MBLUZ P5 , the first spine collected (in 1990). This is a relatively complete impression of most of the left 


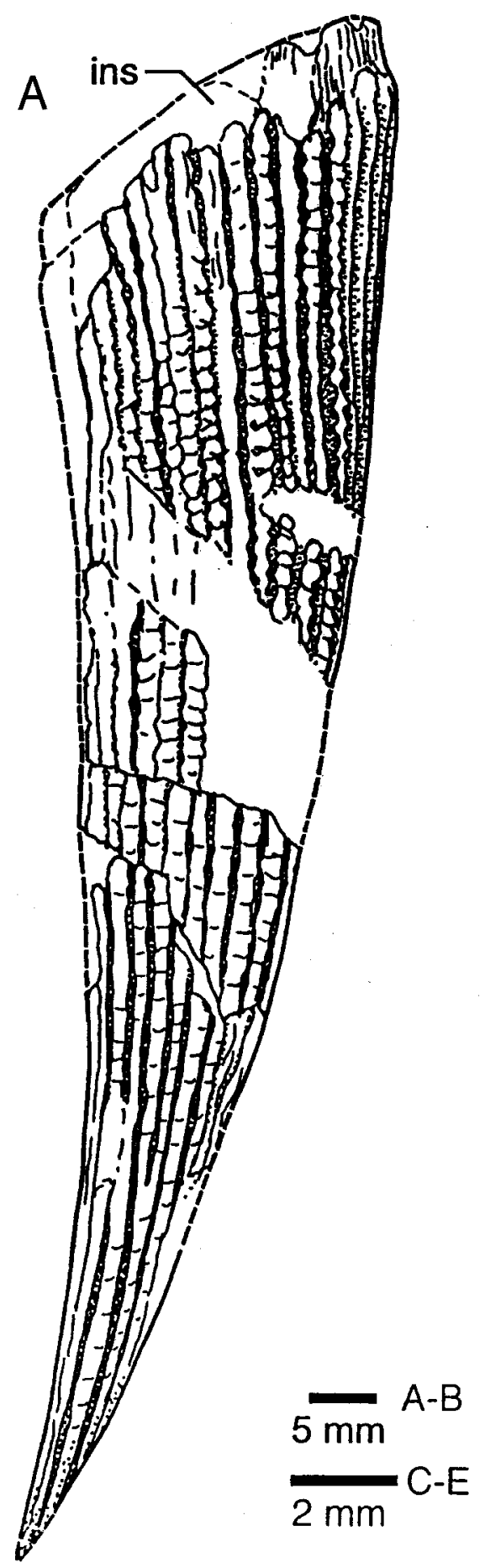

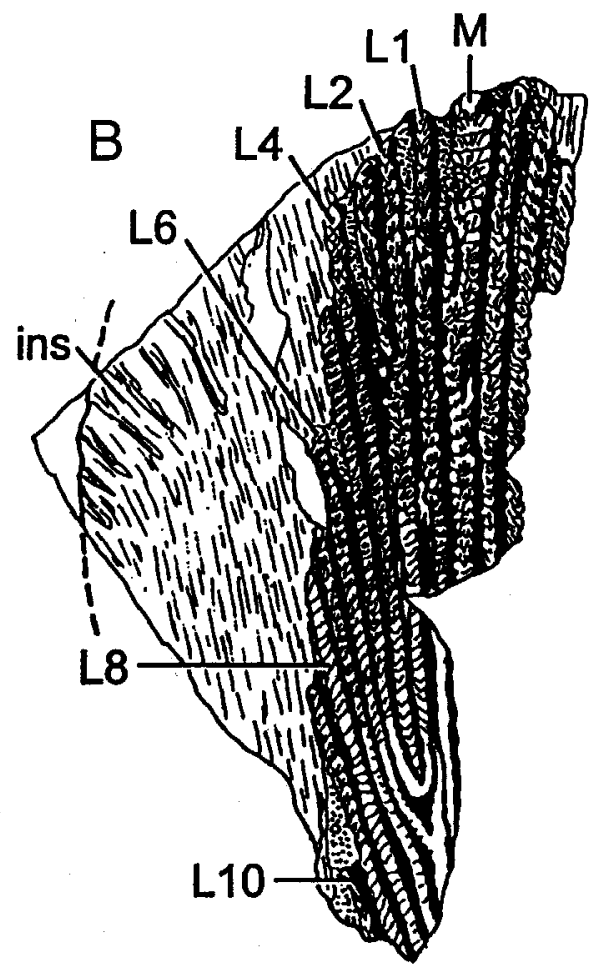

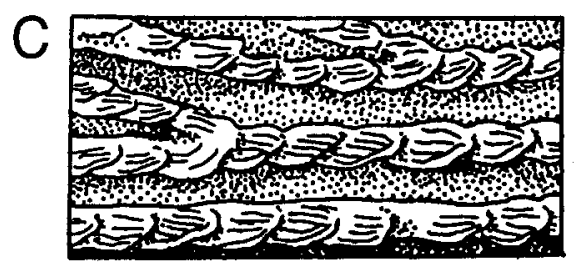

D

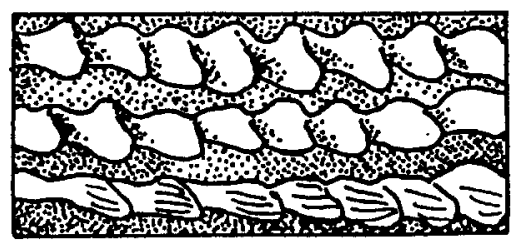

$\mathrm{E}$

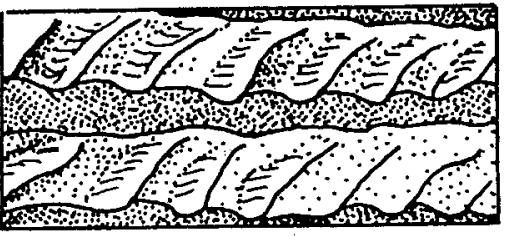

Fig. 15. ?Antarctilamnid chondrichthyan spines, camera lucida drawings. A. MBLUZ P-5, right lateral view. B. MB. f.7630, anterior view showing extent of insertion area (ins). C. Ornament detail of MBLUZ P134, from near the leading edge of the spine. D. Ornament detail of MBLUZ P-7, from the left side, about $23 \mathrm{~mm}$ from the distal end (ornament well preserved only on ventral ridge). $\mathbf{E}$. Ornament detail of MBLUZ P-6, assumed to come from the right side of a large spine. side of a slightly curved fin-spine (Fig. 14B). Total length of about $115 \mathrm{~mm}$ includes a presumed short proximal inserted area (Fig. 15A). The proximal part of the posterior margin is unclear, but estimated maximum width is about $22 \mathrm{~mm}$, suggesting similar proportions to spines of Antarctilamna prisca Young (1982: fig. 5A). However, it is at least twice the size of those spines, with a slightly more curved shape, and the insertion angle (poorly preserved) may have been up to $40^{\circ}$ (35 in Antarctilamna). There are at least 17 ornamental ridges across one side at the prox- imal end, reducing to 12 half-way along the spine, and $2-3$ at the preserved distal end. Ridges are thinner near the anterior spine edge, and 3-4 across the midline apparently lacked ornament. They are continuous, with no convergence of the type seen in Gyracanthus spines. The nodose ornament is not well preserved, but seems generally similar to that of Antarctilamna (Young 1982), with transverse grooves, sometimes oblique, defining the nodes. Towards the posterior edge the ridges are coarser, and separated by distinct grooves about half their width. 
Cross-sectional shape of the spine cannot be determined, but the rounded anterior face with narrow longitudinal ridges compares with the more complete specimen described next. The lateral face is convex near the leading edge, as described by Maisey (1981) for spines of Ctenacanthus, and slightly concave posteriorly (perhaps compressed during preservation).

Specimen MBLUZ P-7 is the largest spine impression (Fig. 14A), $160 \mathrm{~mm}$ long with the tip missing, and represents the second spine type, characterised by greater elongation, with an insertion area and shallower insertion angle, and showing some bifurcation of ornamental ribs. The ornamented surface of both sides is preserved, but the posterior face is unknown. The rounded anterior surface indicates a similar cross section to Antarctilamna prisca about half way along its length, but near the proximal margin the spine is broader (possibly compressed). The distal half of the spine has well-preserved ornament, with occasional bifurcation of the ribs along the leading edge, as illustrated in a spine fragment from Brazil by Janvier \& Melo (1992: fig. 6A). At the preserved distal end are three ornamental ribs on each side, increasing proximally to 15 , counting from the anterior midline, which compares with 15-26 ribs in A. prisca (Young 1982: 828). The ribs are separated by deep grooves oriented parallel to the plane of symmetry of the spine, and thus appearing narrower in anterior than lateral view. The ribs are nodose, each node crossing the rib obliquely in lateral view, and sloping backwards and downwards (Fig. 14E). Again this is closely similar to the ornament of the spine from Brazil (Janvier \& Melo 1992: fig. 6C). The nodes are less widely spaced than in the holotype of $A$. prisca (Young 1989: fig. 4E). A short section of the most posterior preserved ribs shows well-preserved ornament, with $4-5$ widely spaced fine ridges on each node, which are subparallel to slightly radiating to the front from a blunt smooth cusp forming the node. Each cusp points distally, and is deflected slightly away from the leading edge (Fig. 15D). Cusps may point towards the leading edge on ribs closer to it (see Fig. 15C).

In lateral view the leading edge of the spine is slightly curved, not straight as in $A$. prisca. It also differs in its much larger size, and more acute insertion angle $\left(20^{\circ}\right.$ instead of $\left.35^{\circ}\right)$. In Ctenacanthus spines such differences have been attributed to different insertion angles of anterior and posterior dorsal fin spines (Maisey 1981: 18).
It is suggested that both spine types described here could come from the same animal.

Other specimens are incomplete fragments with nodose ridged ornament, which on their own would be indeterminate to genus. For example, Eunemacanthus is only identifiable if the broad median rib down the anterior spine margin is preserved (Maisey 1982: fig. 6). Because they occur in similar lithology to the more complete spines just described, and show the same ornament detail, the following are referred to the same taxon. They provided additional evidence of an extensive insertion area in these spines.

Specimen MBLUZ P-6 is an irregular fragment $(60 \times 20 \mathrm{~mm})$ from a considerably larger spine. The coarse ribs are up to $2 \mathrm{~mm}$ wide, separated by narrow grooves $(\sim 0.5 \mathrm{~mm})$, and their oblique nodes (Figs 14F, 15E) are comparable with the ornament of MBLUZ P-7. A smooth area near the edge of the impression suggests that this is the right side adjacent to an insertion area, towards which the ribs increase in width. An associated flat unornamented element $(30 \times$ $50 \mathrm{~mm}$, incomplete) could be calcified cartilage, with the surface texture as preserved (weathered) resembling abraded bone.

Specimen MBLUZ P-134 $(37 \mathrm{~mm} \times 12 \mathrm{~mm}$ maximum width) has 11 longitudinal ribs and three shorter ribs coalescing along one edge, suggesting proximity to the leading spine edge. Ornament detail is well preserved, showing comparable structure to MBLUZ P-7, but with the radiating point of each cusp directed towards the leading edge of the spine (Fig. 15C), rather than laterally as in MBLUZ P-7 (Fig. 16D). This difference may depend on how far the ribs are from the leading edge.

Specimen MBLUZ P-135 shows the proximal end of a large spine (preserved length of left side $65 \mathrm{~mm} ; 5 \mathrm{~mm}$ thick). The right side has about 11 nodose ribs, with an incomplete insertion area at least $5 \mathrm{~mm}$ wide, and an angle of insertion of about $25^{\circ}$ to the leading edge.

Specimen MB. f.7630 (Fig. 14C, D) is the only specimen showing the full width of the insertion area. It is a large spine, of which about $55 \mathrm{~mm}$ length of the ornamented part preserved. There are nine ornamental ribs on the left side of the widest (presumably central) rib, which is also in the centre of the convexity across the spine (possibly flattened during compaction). The edge of the insertion area is a distinct line connecting the proximal ends of each rib, and clearly delineates the smooth surface inside the deep grooves between ribs from the striated porous texture of 
the inserted portion, which would have been embedded in soft tissue. The insertion angle was low (about $10^{\circ}$ ), increasing to about $35^{\circ}$ at the anterior preserved end (ribs L1-4), where it curved around the front of the spine. The insertion area is about $16 \mathrm{~mm}$ across at right angles to the end of the sixth lateral rib (L6, Fig. 15B).

This specimen shows an interesting pattern of addition of ornamental ribs with growth (Fig. 15B). Short bifurcations on the median ridge to the right (Fig. 14D), and then to the left side proceeding proximally, terminate after a small number of cusps were added (3-4 and 6-7 cusps respectively). Rib L3 is fused to L2 about 10 nodes back, with five isolated more distal tubercles lateral to L2 preceding this bifurcation. Rib L4 terminates much farther back, enclosed between two bifurcations (L2/L5 and L2/ L6). Ribs L7-10 remain separate to the distal preserved edge. This pattern indicates rib addition by bifurcation at the midline, in contrast to the pattern seen in some other shark spines, for example Sphenacanthus, where ribs are added during growth by bifurcation and insertion at the posterolateral margin of the spine (Soler-Gijón 1997: 150).

Specimen MB. f. 7630 also shows the ornament pattern in excellent detail. On the distal preserved part the ribs have a flattened outer surface, presumably indicating wear during life. The widest proximal nodes on the central rib carry about 10 subparallel posteriorly directed fine ridges, but more typically they converge towards a central cusp connecting to the node behind (Fig. 14D). On more lateral ribs (e.g., L4) each node has up to 8 fine ridges converging to a central ridge, which tends to deflect to the lateral side of the rib, before turning distally to the next node.

Comparisons: The two spine types are assumed to belong to the same species. They may be contrasted with the spines of "Ctenacanthus" dealt with by Maisey (1981, 1984). Maisey's (1984) review retained 12 Ctenacanthus species which are of Devonian age, all apparently Famennian except $C$. wrightii, from the Middle Devonian Moscow Shale, Hamilton Group, New York, and $C$. randalli from the Chemung. Maisey (1984: 16) considered all species retained in Ctenacanthus to come from marine deposits. MBLUZ P-5 resembles C. littoni Newberry (Maisey 1981: fig. 8) in curvature, density of ornamental ribs, and lateral compression, but is less elongate, and lacks the long inserted portion. C. clarkei has a similar shape and curva- ture. Janvier \& Melo (1992) compared their incomplete spine from Brazil to this species. However the ornamental ribs are much finer and more closely spaced than in our material, and it appears to be a much thicker spine with a more angular anterior margin in proximal cross-section (Maisey 1981: fig. 9K). C. nodocostatus displays a similar number of ridges (Maisey 1981: fig. 10K), but in detail the nodose ornament in all species he illustrated does not compare closely with that described here, apart from somewhat similar ridges on the nodes in C. littoni (Maisey 1981: fig. $8 \mathrm{~A}$ ).

As noted above, MBLUZ P-5 resembles spines of Antarctilamna prisca Young (1982) in similar proportions and lack of an insertion area, but differs in much larger size compared to the type species, with a slightly more curved shape, and higher insertion angle. Antarctilamna seriponensis from Bolivia (Gagnier et al. 1988: fig.11B; now considered to belong to the Lochkovian Santa Rosa Formation; Janvier \& Melo 1992: 203), differs in presence of an insertion area, and from the other spine type described above in its shorter more triangular shape, with straight anterior and posterior margins, and more rounded cross section.

A detailed resemblance was noted above in the ornament of the incomplete spine described from Brazil by Janvier \& Melo (1992). There is also an overall similarity (cf. Janvier \& Melo 1992: fig. 6A with the middle portion of MBLUZ P-7 in Figure 14A). We suggest that these South American occurrences may represent the same taxon. An undescribed "chondrichthyan spine" from the Falkland (Malvinas) Islands illustrated by Lelièvre et al. (1993: fig. 7.3Q) is of similar age (late Middle Devonian). A similar bifurcation pattern and low insertion angle is also seen on a spine from the Aztec fauna of Antarctica, which Warren et al. (2000: 238) considered "not gyracanthid in origin". This may belong to a chondrichthyan closely related to the owner of the Venezuelan spines, but differing in its ornament of widely separated and intricately branched tubercles on the ribs (see Warren et al. 2000: fig. 12B, C).

Class Acanthodii Owen, 1846

?Family Ischnacanthidae Woodward, 1891

Genus Machaeracanthus Newberry, 1857

\section{Machaeracanthus sp. indet.}

Figs 14G, 16D, E 
Synonyms:

1992 "Espinas de un acanthódido asignado al género $M a$ chaeracanthus" - Casas et al.: 6 .

1997 "espinas asignadas al género Machaeracanthus" - Berry, Casas, Moody \& Young: 127.

2000 Machaeracanthus - Young, Moody \& Casas: 759.

Material: MBLUZ P-133, 902-3, 1112, 1114-5, 1346, 1404-06, 1531-2

Localities: All specimens come from Locality 118 (Fig. 1), mostly as float samples, and probably mainly derived from the same sandstone bed as MBLUZ P-1346, which was extracted from a large block fallen from an inaccessible high sandstone bed above plant locality 9 (Fig. 1D).

Remarks: Zidek (1981) provided evidence that Machaeracanthus is an ischnacanthid acanthodian, but Janvier (1996: 181) questioned its higher level affinities, since some associations combine characteristics of acanthodians (e.g., paired fin spines) and chondrichthyans (scale histology, teeth). Possibly this casts doubt on the monophyly of the class Acanthodii, but this issue is currently unresolved, and the traditional acanthodian assignment is followed here.

Description: MBLUZ P-133 is a sandstone block containing five partial spine impressions. One latex cast of a better preserved example forms the basis of this description. It is a slightly curved spine impression $98 \mathrm{~mm}$ long, and incomplete at both ends. It is mainly smooth, with several prominent longitudinal ribs or angles. The assumed dorsal surface (Fig. 16D) is triangular in section, with a rounded gently curved apical ridge sloping steeply to the back, and a slightly more concave sloping surface to the front (Fig. 16B). Both surfaces finish as anterior and posterior horizontal flanges or ribs, which were evidently thin and broad. These are poorly preserved, so their width is restored from the more complete sections. A slight decrease in width towards the assumed distal end is consistent with a clear increase in width of the ventral surface towards the opposite end (from 7 to $12 \mathrm{~mm}$ ). In dorsal view the anterior rib was apparently narrow at the proximal preserved end, but broader distally (Fig. 16D). The posterior rib seems to have been narrow further distally, becoming broader only at the distal preserved end of the ventral surface. Only $35 \mathrm{~mm}$ length of the ventral surface is preserved; it is slightly convex, with poorly preserved narrow longitudinal ribs and grooves.
The cross section (Fig. 16E) is typical of spines of Machaeracanthus (e.g., Denison 1979: fig. 33I-K, Young 1992: figs 2, 3), but there is nothing quite comparable in the cross sections of the 10 species considered to be valid by Zidek (1981: fig. 2). Direct comparison with the specimen of $M$. kayseri (MB. f.709) described by Gross (1933a: pl. 5, fig. 12) indicates that this is a more elongate and larger spine, with greater breadth (up to $18 \mathrm{~mm}$ ) in its middle part. MB. f.709 is about $88 \mathrm{~mm}$ long and $11 \mathrm{~mm}$ at maximum width, and both dorsal and ventral ribs are much more pronounced than in P-133. A larger example of $M$. kayseri (MB. f.708) has a more rounded dorsal rib than in published illustrations (Gross 1933a, Denison 1979).

Other specimens (not studied) containing similar spines may be briefly noted. MBLUZ P-902 is a large block with eight partial spine impressions, one showing a good cross-section of a $\mathrm{Ma}$ chaeracanthus spine. P-903 is a similar sample, with at least four impressions. MBLUZ P-1115, 1348, 1404-06, 1532 contain one or two $\mathrm{Ma}$ chaeracanthus spine impressions, some incomplete. Other similar samples are listed in the Appendix.

Comparisons: V.T. Young (1986) described Machaeracanthus spines from the Ohio Range in Antarctica, and Young (1992) described one from the Ellsworth Mountains, and noted other records from Gondwana. The first record of Devonian vertebrates from South America, by Katzer (1897) from the Lower Devonian of the Amazon Basin, included mention of a Machaeracanthus spine, and other authors (Kegel 1953, Santos 1961) recorded Machaeracanthus from the Givetian Pimenteira Formation of Brazil. The same fauna has produced the chondrichthyan spine described by Janvier \& Melo (1992), which is closely similar to specimens described above. Spines assigned to Machaeracanthus are also known from the Early-Middle Devonian of Morocco and southern Europe (summarised by Lelièvre et al. 1993). The only younger examples are from the Eifelian ( $M$. westfalicus, Rheinland; $M$. peracutus, $M$. major and $M$. sulcatus, eastern US), and Givetian ( $M$. longaevus, $M$. retusus) of the eastern US, the latter species possibly extending into the Frasnian (Wells 1940). The new Venezuelan occurrence would thus be one of the youngest known records of the genus, comparable with its upper stratigraphic range in the eastern US. 


\section{Acanthodii indet.}

Fig. 16A-C

Material: MBLUZ P-1348-49, 1532, 1536-39, 1696-97 (spine impressions), and MBLUZ P-5001-04 (scales from acid dissolution).

Localities: All spine impressions come from Locality 118, and isolated scales come from Locality 139 (Fig. 1).

Remarks: Included here are some spine types which apparently differ from Machaeracanthus spines just described, plus a few scales obtained from acid dissolution of calcareous samples.
Description: MBLUZ P-1696 is a large block with five gently curved spine impressions, the largest about $140 \mathrm{~mm}$ long and $15 \mathrm{~mm}$ wide. They differ from the more typical Machaeracanthus spines in having a faint sculpture of fine longitudinal ribs about $2 \mathrm{~mm}$ apart, with a single, larger longitudinal ridge near the posterior edge, perhaps indicating a different machaeracanthid or haplacanthid spine type. MBLUZ P-1346 is a large sandstone block with up to 15 spine impressions and associated weathered plates, all poorly preserved and unprepared, but including
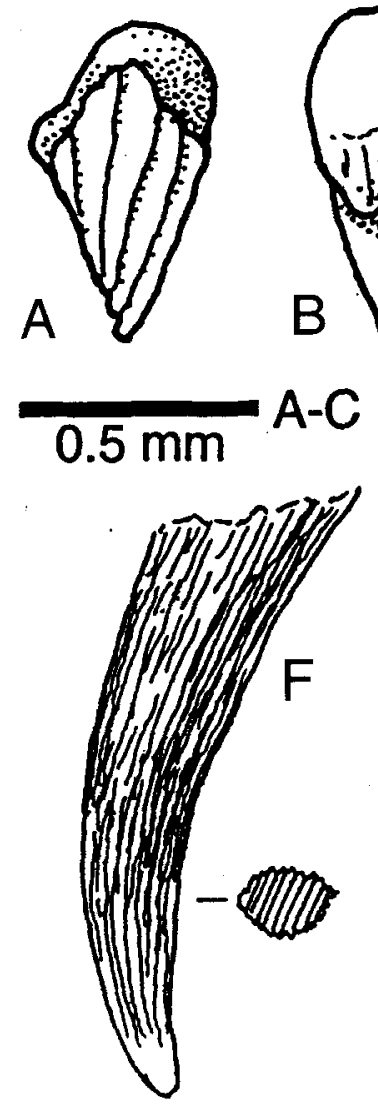
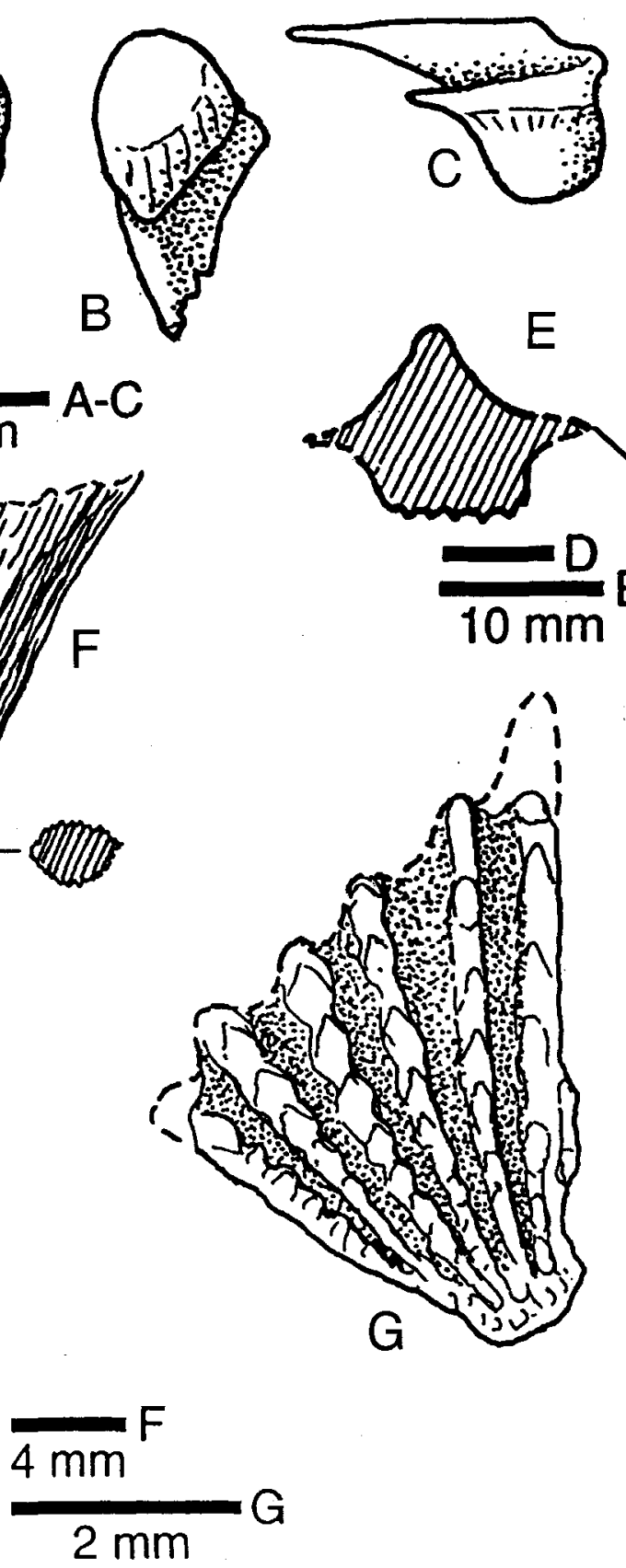

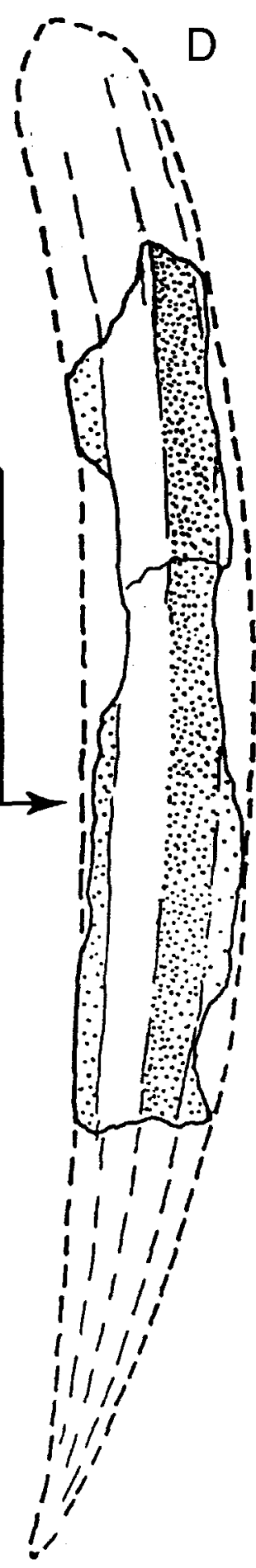

Fig. 16. A-C. Acanthodian indet., sketch restoration of a scale from acid residue in dorsal (A), ventral (B) and lateral (C) views (MBLUZ P5001). D, E. Machaeracanthus sp., fin spine (MBLUZ P-133) restored in dorsal view (D), with cross-section at level indicated (E). F. Sketch of osteolepid tooth (MBLUZ P-251), with cross-section at level indicated. G. Dipnoan toothplate, MBLUZ P-124. 
similar spines to those of MBLUZ P-1696. MBLUZ P-1697 also has partial impressions of two similar spines.

Some small scales $(0.08-0.5 \mathrm{~mm}$ long) were obtained by etching a calcareous bed at the main Bothriolepis locality, and one is illustrated in Figure 16 (MBLUZ P-5001). It shows ridged ornament on the crown, although another example has a smooth and rounded crown. Somewhat similar scales from the Colombian fish locality were named Cheiracanthoides? by Janvier \& Villarroel (2000: fig. 5B, C), who noted that such ribbed scales also occur in various Late Devonian acanthodians, including Homalacanthus and various diplacanthids. The histology of these scales has not been investigated, so assignment to the Acanthodii is provisional, since similar external morphology is seen in several major groups (e.g. chondrichthyans, actinopterygians; see Schultze 1996: fig. 12).
Class Osteichthyes Huxley, 1880

Subclass Sarcopterygii Romer, 1955

Remarks: Until recently, the only Devonian osteichthyans recorded from South America were isolated scales from the Middle and Late Devonian of Bolivia and Brazil (Janvier \& SuárezRiglos 1986, Janvier \& Melo 1987), and fish scales from the "Las Palmas" and Floresta regions of Colombia (Schmidt 1938, Mojica \& Villarroel 1984). Janvier \& Villarroel (2000) have recently reported four osteichthyan taxa from the Late Devonian of Colombia. A scale earlier identified as "crossopterygian" by Walter Gross (see Schmidt 1938: pl. 1, fig. 12) may be a cosmoid osteolepiform scale such as described below, but is supposedly of Carboniferous age, as was originally assumed for the fish assemblage from Caño Colorado Sur. At least two sarcopterygian groups (osteolepiforms and dipnoans) are
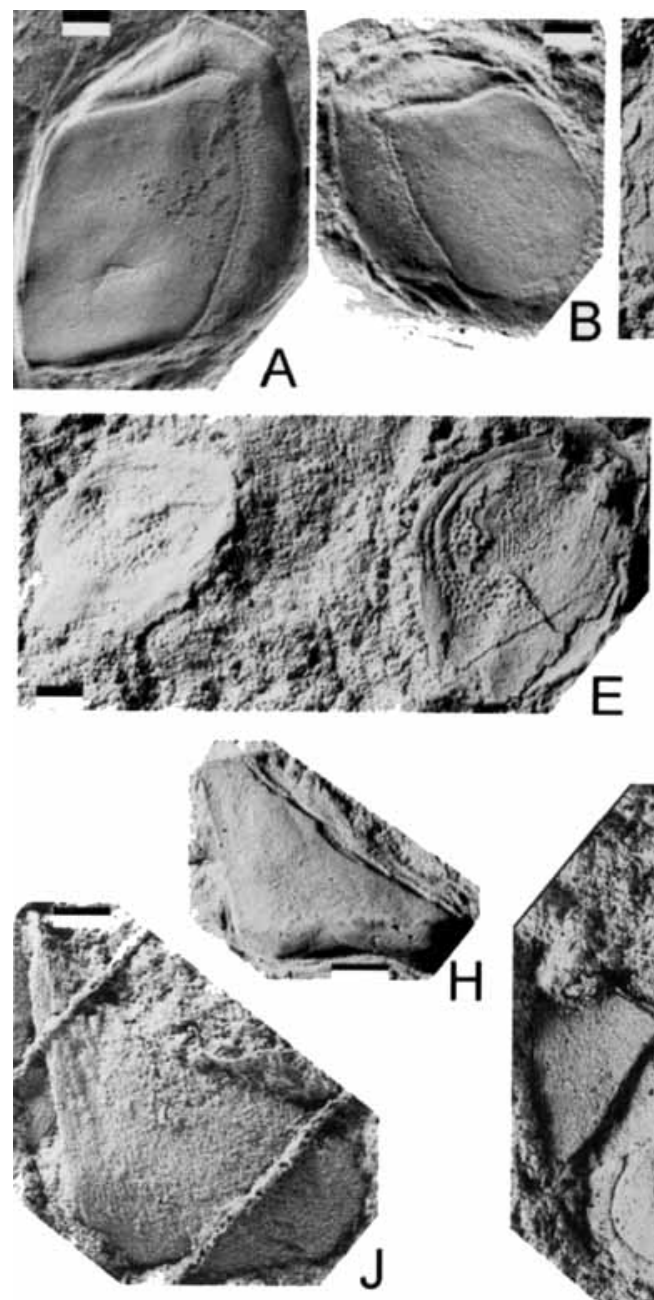
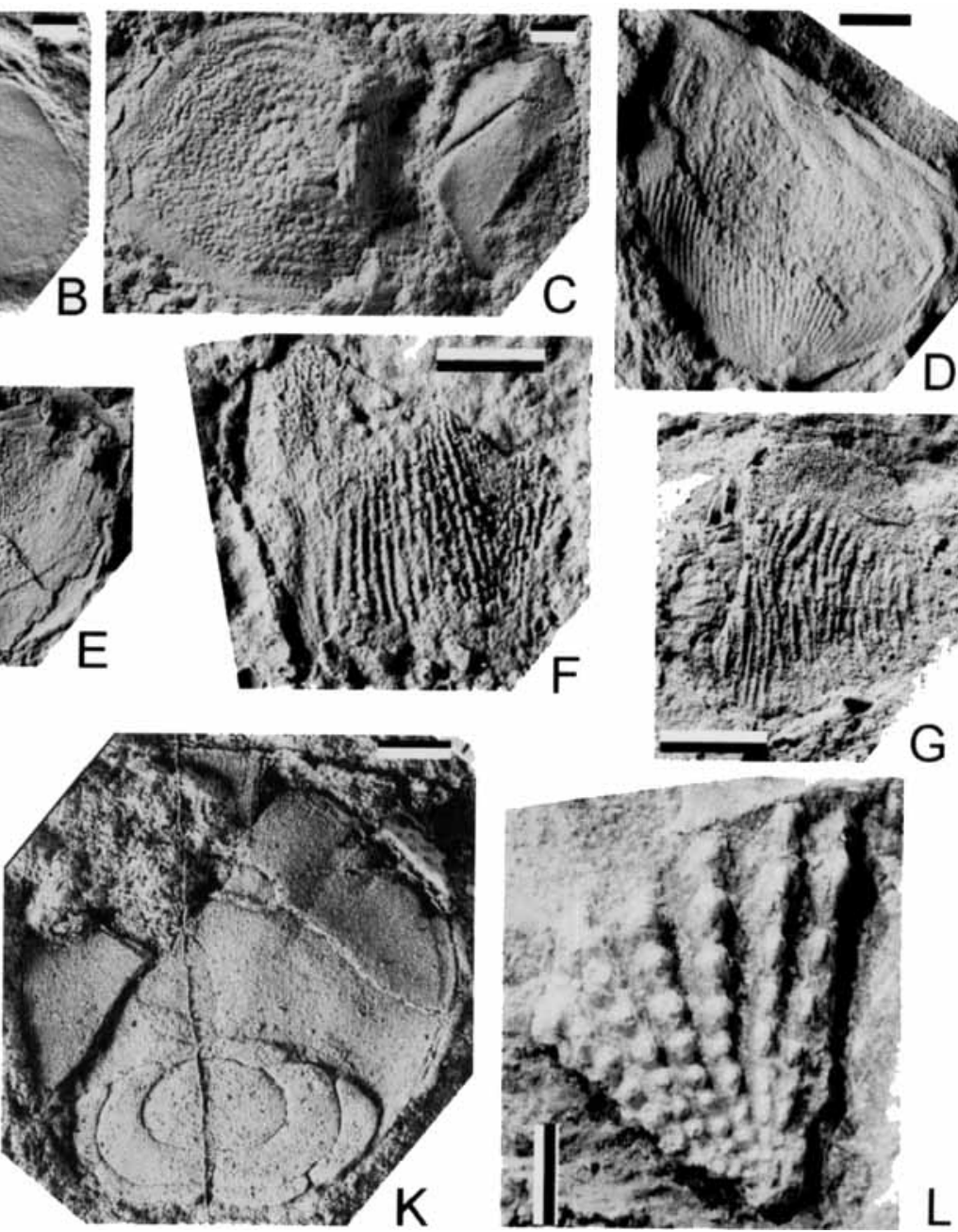

Fig. 17. A-C. Osteolepid gen. et sp. indet., cosmoid scales. A. MBLUZ P-354 ( $\times 2.5)$. B. MBLUZ P-346 $(\times 2.5)$. C. MBLUZ P-109 (×2.5). D-G. Indeterminate sarcopterygian scales. D. MBLUZ P-143 $(\times 4)$. E. MBLUZ P-146 $(\times 2.5)$. F. MBLUZ P-359b $(\times 6)$. G. MBLUZ P-359a $(\times 6)$. H, J. Osteichthyan ?clavicles, MBLUZ P-108 (H), MBLUZ P-232 (J) (both $\times 3)$. K, L. Dipnoan gen. et sp. indet. K. Scale, external view (MBLUZ P-158A, ×6). L. Toothplate (MBLUZ P-124, $\times 4$ ). All photographs of latex casts (except $\mathrm{L}$ ) whitened with ammonium chloride. Scale bar $=2 \mathrm{~mm}$. 
clearly represented in the material from Caño Colorado Sur. A few isolated scales may indicate that other groups are also present, but for the moment these are left in open nomenclature.

\section{Infraclass Rhipidistia Cope, 1871 \\ Order Osteolepiformes Berg, 1940 \\ Family Osteolepidae Cope, 1889}

\section{Osteolepid gen. et sp. indet.}

Figs $16 \mathrm{~F}, 17 \mathrm{~A}-\mathrm{C}$, ?H-J

Synonyms:

1992 "Escamas y dientes de un Osteolepidae" - Casas et al.: 6.

1997 "osteolepiforme similar al género Koharalepis" - Berry, Casas, Moody \& Young: 128.

2000 "osteolepiform sarcopterygian" - Young, Moody \& Casas: 759

Material: MBLUZ P-108, 232 (?clavicles), 122-123, $125-126,159,178,227,421$ (scales and indeterminate isolated bones); 69, 91-93, 99, 107-108, 110, 138, 141-142, $169-170,196,204,226,255,279-280,310,314-315,317$, $319-320,336,346,351-354$ (isolated scales); 104, 137, 217, 251 (isolated teeth). See Appendix for full listing.

Locality: All material comes from the main fish locality at Caño Colorado Sur (Locality 139, Fig. 1).

Description: Smooth scales with the characteristic shiny surface of the tissue cosmine are a common component of the assemblage at locality 139 (Fig. 17A-C). Scales up to $20 \mathrm{~mm}$ across (e.g., MBLUZ P-169, 170, 279, 317) indicate a large fish similar in size to Koharalepis from the Antarctic Aztec fauna (Young et al. 1992), or Megalichthys from the Carboniferous of Euramerica. Specimen MBLUZ P-354 is a typical rhomboid flank scale, with a cosmine-covered exposed part $9 \mathrm{~mm}$ high showing a small pitline (Fig. 17A). The overlapped area is separated by a shallow groove, and shows a dorsal process or peg. The peg and socket connection within scale rows is probably primitive for osteichthyans generally (e.g., Schultze 1969: fig. 41). MBLUZ P109 (Fig. 17C) shows a similar incomplete scale associated with a larger example (13 $\mathrm{mm}$ across) which lacks cosmine, presumably by resorption, a well-known condition in osteolepids (e.g., Jarvik 1948: fig. 6, Young et al. 1992: fig. 16D).

A few samples included isolated teeth (see list above). MBLUZ P-251 is about $10 \mathrm{~mm}$ long, curved, with the surface covered with fine ridges except at the tip where they are worn off (Fig. 16F). This tooth has a flattened cross-section about $3 \mathrm{~mm}$ from the tip with probably a slight ridge or carina down the posterior edge. Other possible bones of the head and shoulder girdle have been provisionally identified (see Appendix), but not studied in detail. Two small triangular bones (MBLUZ P-108, 232) may be incomplete clavicles (Fig. 17H-J), which could also belong to other osteichthyan groups, such as actinistians (e.g., Cloutier 1996b: figs 13-14).

Comparisons: Cosmoid scales of this type are widely known, with an age range (Schultze 1994) of Eifelian (Caithness, Scotland) to the Carboniferous/ Permian in both hemispheres (e.g., Thomson 1964, Fox et al. 1995). Some classic Middle-Late Devonian localities in Europe include Scotland (Jarvik 1948) and the Baltic region (Gross 1956). From the southern hemisphere they are more recently described from Australia (e.g., Young \& Gorter 1981: fig. 28, pl. 9), and Antarctica (Young et al. 1992). The only other definite Devonian record from South America is Janvier \& Villarroel's (2000: 748) report of "rare cosmine-covered dermal bone and scale fragments", in the Cuche Formation of Colombia.

Infraclass Dipnoi Müller, 1845

Dipnoan gen. et sp. indet.

Figs $16 \mathrm{G}, 17 \mathrm{~K}-\mathrm{L}, 18 \mathrm{D}$

Synonyms:

1997 "escamas como las descritas para ... Griphognathus" Berry, Casas, Moody \& Young: 128.

2000 "dipnoan ... lungfish remains" - Young, Moody \& Casas: 759.

Material: MBLUZ P-124 (isolated toothplate); MBLUZ P-158 (cosmoid scale). Other scale material may also belong to dipnoans, but is dealt with below (Sarcopterygii, indet.). For a full listing see Appendix.

Locality: The main fish locality at Caño Colorado Sur (Locality 139, Fig. 1).

Remarks: The specimens described below are the oldest lungfish remains recorded from South America, today the home of one of only three surviving genera (Lepidosiren). Fossil lungfish toothplates are well known from the Cretaceous and Tertiary of South America (e.g., Schultze 1991), and the first Palaeozoic occurrences (Carboniferous?) were reported by Hunicken (1992).

Description: The only toothplate so far identified is MBLUZ P-124 (Figs 16G, 17L), possibly a pterygoid toothplate from the right side. Beneath its posterior margin is a thick irregular bone separated by matrix from the toothplate, which might be part of the palatoquadrate. An 
alternative interpretation is a left toothplate from the lower jaw, which might be suggested by the shape of the associated fragment (Thomas Gassner, pers. comm.). The toothplate has six radiating denticle rows. The anteromesial row is $4.5 \mathrm{~mm}$ and the posterolateral row $3.5 \mathrm{~mm}$ in length. The posterolateral row has 6 denticles, the next 8-9; rows $3-5$ have 9 denticles each, and the most anteromesial row has 8 denticles, although it may be incomplete distally. The rows are short and straight posteriorly, becoming longer and slightly curved anteriorly. The denticles are small and crowded mesially (at the ossification centre), and increase in size towards the edge of the plate, where they are noticably more widely spaced, particularly the more anterior rows. Each denticle is slightly inclined away from the radiation centre, although this is less marked in the posterior rows, where denticles are more rounded, presumably due to wear. All of these features are seen in various Devonian-Carboniferous dipnoan toothplates.

The tooth rows seem more distinct and widely separated in the toothplates of Rhinodipterus secans illustrated by Gross (1956: pl. 6), and in Scaumenacia curta from Miguasha (Cloutier 1996a: fig. 6). There are less denticles per row in the small "chirodipterid" toothplates from the Upper Devonian of eastern Australia illustrated by Jones \& Turner (2000), which have "typically 5 , up to 8 " denticles per row. The outer teeth are more "recumbent" in the Early Carboniferous Delatitia from Victoria (Long \& Campbell 1985: fig. 4), a feature used in the diagnosis for that genus. The fact that the rows diverge from the ossification centre, rather than spread out from along the posterior margin of the toothplate, is a point of difference to the toothplates of Eocteno$d u s$ from the Late Devonian of Victoria (Long 1987: fig. 1B-D). However in size and shape, and in the number of both rows and denticles, MBLUZ P-124 compares well with the posterior parts of toothplates of Dipterus valenciennesi illustrated by White (1965: pl. 1). Many isolated dipnoan toothplates have been assigned to species of Dipterus, but in the absence of other information these assignments are doubtful (Denison 1974: 45); a more recent practice is to leave isolated toothplates unnamed, as did Reed (1985) for those from the Late Devonian of Red Hill Nevada. Long (1987: 311) questioned the occurrence of Dipterus outside of the type area (Middle Devonian of Scotland), and perhaps the Baltic sequence. Since other aspects of the Venezuelan fauna indicate affinities with the Aztec fish fauna of Victoria Land, Antarctica, comparisons with the poorly known dipnoan remains (toothplates) from that sequence are relevant. Denison (1974: 43) noted similarities to Dipterus in an undescribed specimen from Antarctica, presumed to come from the Aztec fauna. Long \& Campbell (1985: 93) mentioned other toothplates showing similarities to Ctenodus and Delatitia, and ?Eoctenodus is a more recent assignment (Young et al. 1993: 248). The only illustrated specimen (Campbell \& Barwick 1987: fig. 2) shows a toothplate from Mt. Crean, Lashly Range, which has about 12 tooth rows, with seven recumbent teeth in the anterior row. This is quite differently developed to the Venezuelan specimen.

In summary, the Venezuelan toothplate shows similar morphology to the toothplates of Dipterus valenciennesi, but this does not imply any close relationship. However, in the absence of contrary evidence, it can be assumed that MBLUZ P-124 belonged to the same animal which produced the cosmoid scale described next.

Specimen MBLUZ P-158, a large ovoid lungfish scale some $16 \mathrm{~mm}$ long, shows the central cosmoid surface with well-developed "Westolllines" (Figs 17K, 18D), a characteristic feature of dipnoans. This example compares well for example with dipnoan scales attributed to Dipterus and Rhinodipterus from Bergisch Gladbach (e.g., Ørvig 1961: pl.5), but in these scales the exposed cosmoid part comprises some $50 \%$ of scale area, and they are no more than half the size of MBLUZ P-158, in which the posterior exposed part comprises only about one third of scale length. Large scales of this type attributed to Rhinodipterus secans were illustrated by Gross (1956: fig. 22, pl. 7). Scales of Chirodipterus australis illustrated by Pridmore \& Barwick (1993: figs 11, 13), are of similar size. Larger scales from Bergisch Gladbach (referred to as dipnoan gen. et $\mathrm{sp}$. indet.) were illustrated by Ørvig (1969). The posterior edge of the exposed free field of MBLUZ P-158 is slightly raised, and would have abutted against the exposed part of two adjacent scales; the overlapped part has a honeycomb-like texture formed by the pits of the middle scale layer. Both features are as described in Ch. australis scales (Pridmore \& Barwick 1993: 170). A more compact area on the left side, adjacent to the cosmine, is part of the free field that was not cosmine-covered, much as illustrated by Gross (1956: fig. 23A). The ovoid shape as reconstructed (Fig. 18D) compares clo- 
sely with the scales from Bergisch Gladbach illustrated by Ørvig (1969).

\section{Sarcopterygii gen. et sp. indet.}

Figs 17D-J, 18A-C

Synonyms:

1992 "Placas de un Phyllolepidae" (pars) - Casas et al.: 6.

Material: MBLUZ P-128, 143, 146, 355, 359 (isolated scales); P-108, 232 (osteichthyan ?clavicles); see Appendix for full listing.

Locality: The main fish locality at Caño Colorado Sur (Locality 139, Fig. 1).

Remarks: Various small osteichthyan scales in the collection differ from those described above in lacking cosmine, with instead an ornament of fine ridges. As discussed below these could also belong to dipnoans, but assignment to other sarcopterygian groups (porolepiforms, Actinistia) cannot be excluded. The listed specimens are described below, and some similar scales occur in other samples (see Appendix). Two triangular elements figured above may be incomplete clavi- cles of the osteolepid, but one or both could also belong to other osteichthyan groups.

Description: The two possible clavicles (Fig. 17H-J) may belong to the osteolepid, as shoulder girdle bones often have an ornamented surface in this group. On the other hand there is resemblance to other osteichthyan groups, such as actinistians (see Cloutier 1996b: figs 13-14). The various scales included here all lack cosmine. Loss of cosmine by resorption is well documented amongst individuals of cosmine-covered species, including osteolepids as noted above, and also dipnoans like Dipterus (e.g., Forster-Cooper 1937: 225-227, pl. 8, fig. 16), and Rhinodipterus (e.g., Gross 1956: fig. 23B). In addition, phylogenetic loss of cosmine has occurred independently in various sarcopterygian groups. Amongst dipnoans it is first recorded in Griphognathus, known from the Frasnian of Germany and Australia (Schultze 1969, Miles 1977, Campbell \& Barwick 1987). Other groups (osteolepiforms, porolepiforms, actinistians) also have similar scales by that time.

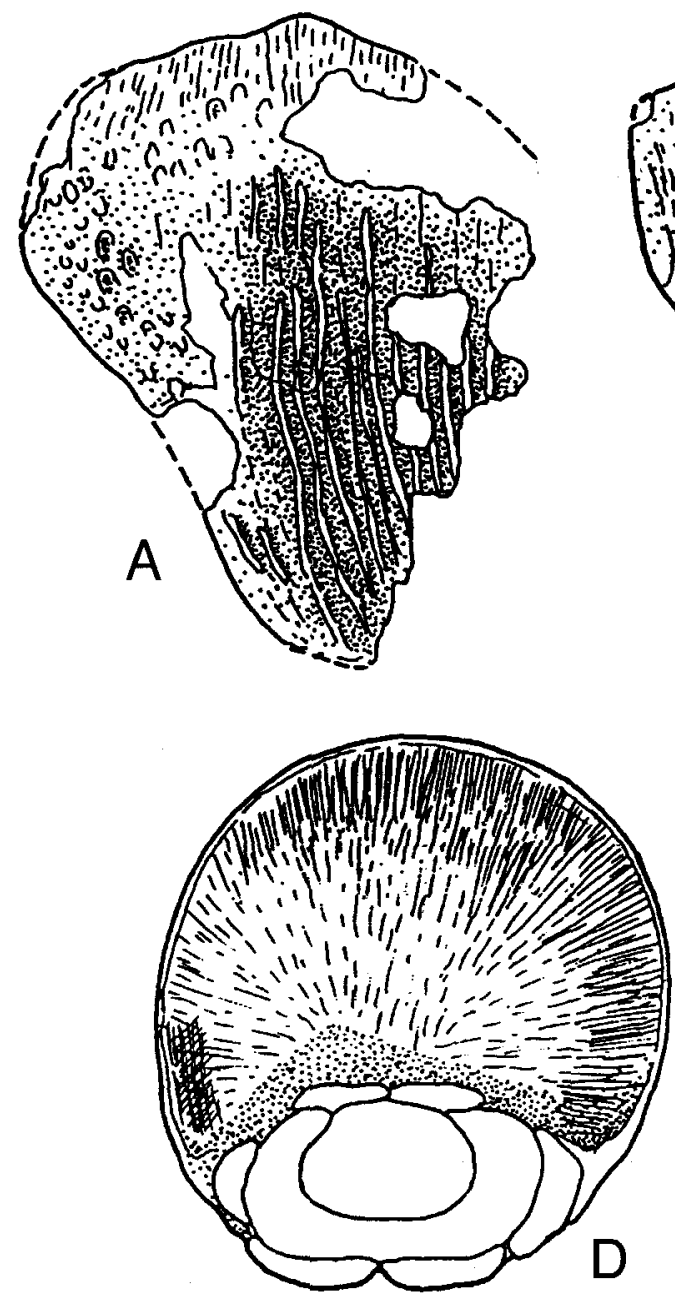

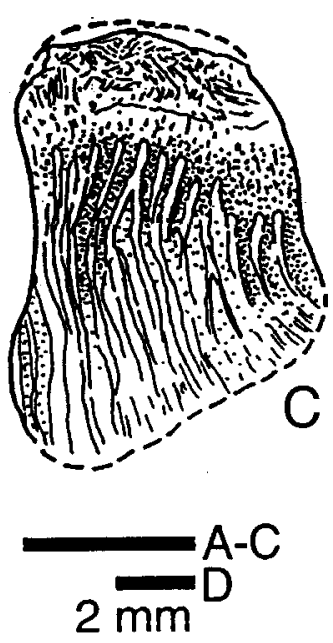

Fig. 18. A-C. Camera lucida drawings of indeterminate sarcopterygian scales, two occurring together on one sample (MBLUZ P-359). A. MBLUZ P-128. B. MBLUZ P-359b. C. MBLUZ P-359a. D. Dipnoan gen. et sp. indet., restoration of cosmoid scale, MBLUZ P-158A. 
Three incomplete examples of small striated scales are preserved on MBLUZ P-359. The largest fragment $(5 \times 4 \mathrm{~mm})$ may be symmetrical, with a notched anterior margin (Fig. 18B). The unornamented anterior part bears a few widely spaced tubercles (tub). The ornamented "free field" carries about 15 continuous subparallel ridges on the left side, converging posteriorly towards the assumed midline. The dipnoan Fleurantia from Miguasha, Canada, has similar scales (Cloutier 1996a: fig. 9D, E), but ridges are less regular and more numerous (up to 50 per scale). Ridge micro-ornament is not preserved in the Venezuelan specimens (Fig. 17F, G). A smaller example $(5 \times 3.5 \mathrm{~mm}$; Fig. $18 \mathrm{C})$ may be compared with a small specimen of Scaumenacia curta from Miguasha (Cloutier 1996a: fig. 9A), which has scales of similar size, but much shorter and broader, and again with more ridges (30-50) per scale. Specimen MBLUZ P-128 shows a similar striated scale (Fig. 18A), with small anterior tubercles of the type proposed by Ørvig (1957: 406-410) as a means of distinguishing porolepiform scales from those of other sarcopterygians. However such tubercles are probably primitive for sarcopterygians, being now documented also in lungfishes (Schultze 1992: fig. 9) and actinistians (Cloutier 1996b). A few tubercles suggest a horse-shoe shape, which seems to face posteriorly rather than anteriorly as previously described (e.g., Ørvig 1957: fig. 10, Cloutier \& Schultze 1996: fig. 16).

The similar ridged scales of Scaumenacia and Fleurantia from Miguasha are difficult to distinguish (Cloutier 1996a), but as well as more numerous ridges their scales have much more extensive overlaps than observed here. Griphognathus from Bergisch Gladbach has both striated and cosmoid scales, but again the former have many more ridges than in these elements (Schultze 1969: fig. 32, pl. 9). Scales of the actinistian Miguashaia show a variety of surface structure including fine ridges, which again are much more densely packed than those described here (Cloutier 1996b: fig. 16). The slightly older Gondwanan coelacanth Gavinia has more similar scales, with a smaller overlapped region, and up to 25 subparallel to slightly wavy ridges with few bifurcations (Long 1999: figs 4B, 11A). The porolepiforms Glyptolepis and Quebecius also have somewhat similar scales (e.g., Gross 1933b: pl. 6, fig. 20, Cloutier \& Schultze 1996: fig. 16F).

It is possible that these scales also belong to a dipnoan, perhaps the same taxon as the toothplate and cosmoid scale described above, but other sarcopterygian groups cannot be excluded without more complete material.

Comparisons: Various round scales and other elements with ridged ornament have recently been described from the Cuche Formation in Colombia. Janvier \& Villarroel (2000) assigned them to three osteichthyan groups (Actinopterygii, holoptychiid and rhizodontid sarcopterygians). In spite of uncertainty in identifying the ridged elements just described, it can be established that none of these groups is represented in the Venezuelan material studied to date. Actinopterygian scales have a distinctive rhomboid shape with a prominent dorsal peg (Janvier \& Villarroel 2000: fig. 14). The special tubercles noted above exclude the possibility that the small ridged elements might be other bones of actinopterygians, as illustrated by Janvier \& Villarroel (2000: fig. 12). Finally the much coarser wavy ridges of scales assigned to Holoptychius sp. by Janvier \& Villarroel (2000: pl. 5, figs 9-10) do not compare closely with the elements described above.

\section{Acknowledgements}

The main collection was obtained in July 1992, with logistic support from the Biological Museum, University of Zulia, and field assistance provided by A. L. Viloria, G. Mosco, J. Coty, V. Gutierrez and E. Narvaes. Additional help with collections was provided by Ascanio Rincón, Alfredo Perez, Jhonny Casas, and Belkis Moody. Dr Chris Berry (Cardiff University) sent the first shark spines, and provided much information on localities, and base maps of the area. Craig Harvey provided unpublished information on spore occurrences from his $\mathrm{Ph} . \mathrm{D}$ thesis, and both are thanked for comments on the draft manuscript. Jhonny Casas supplied details on the local geology. Dr J. Long provided comparative material from Antarctica, and photographs of specimens from $\mathrm{Ta}$ tong in Victoria. Maria Lourdes de Gamero (Caracas) supplied a contact address for J.M. Bowen, who provided information on early fossil collections from the Sierra de Perijá. In Paris G.C.Y. discussed and compared the Venezuelan and Colombian faunas with $P$. Janvier, under a visiting professorship at the Muséum national d'histoire naturelle (1999). In Berlin (Museum für Naturkunde), Dr Thomas Becker gave information on Devonian stratigraphy and glaciation in South America, Thomas Gassner gave advice on the dipnoan toothplate, and Drs Rodrigo Soler-Gijón, Markus Otto and Professors Hans-Peter Schultze and Gloria Arratia discussed many points concerning placoderms, sharks, osteichthyans, and editorial matters. Dr Kathrin Dietze provided much assistance and support in Berlin, and Petra Ebber is thanked for preparing the German abstract, and for general assistance in the Museum für Naturkunde. Andreas Schnock (Berlin) and Brian Harrold (Australian National University, Canberra) provided computer assistance, and Drs R. E. Barwick, and J. Caton (Canberra) and Elke Siebert (Berlin) provided help with computer generation of the illustrations. A. Haupt assisted with translation from the German of various papers. Dr C. Burrow commented on the acidetched scales. Photography was carried out by R.W. Brown 
(Canberra) and Frau W. Harre (Berlin); Dr M. Otto photographed the dipnoan toothplate. Assistance in preparation of the Spanish abstract was provided by Belkis Moody and Dr Angel Viloria. The Alexander von Humboldt Foundation gave funding for sending selected specimens to Berlin, where Lutz Berner prepared some of the material. G. C. Y. acknowledges the support of the Alexander von Humboldt Foundation for six months in Berlin $(2000,2001)$ at the Museum für Naturkunde under a Humboldt Award 1999, when most of the descriptions and manuscript for this work were completed. For provision of facilities in the Institute für $\mathrm{Pa}$ läontologie, Museum für Naturkunde, Berlin, for initiating the project proposal, and for discussion and assistance on many points, we are indebted to Professor Dr H.-P. Schultze, Berlin. The publication costs have been kindly provided by the Alexander von Humboldt Foundation.

\section{References}

Askin, R. A., Barrett, P. J., Kohn, B. P. \& McPherson, J. G. 1971. Stratigraphic sections of the Beacon Supergroup (Devonian and older (?) to Jurassic) in South Victoria Land. - Publication of the Geology Dept, Victoria University of Wellington, Antarctic Data Series 2: 1-88.

Benedetto, G. 1980a. Síntesis bioestratigráfica del Paleozoico tardío de la Sierra de Perijá, Venezuela. - Annais da Academia Brasileira de Ciências 52: 827-839.

- 1980b. Bilvalvos Pensilvanianos de la Formación Caño Indio, Sierra de Perijá, Venezuela. - Boletín de Geología 14(26): 197-245.

- 1984. Les brachiopodes devonicus de la Sierra de Perijá (Venezuela). - Biostratigraphie du Paleozoique (Brest) 1: $1-191$.

Berg, L. S. 1940. Classification of fishes, both Recent and fossil. - Trudy Zoologicheskogo Instituta. Akademiya Nauk SSSR. Leningrad 5: 87-517.

Berry, C. M. 1994. First record of the Devonian lycophyte Leclercqia from South America. - Geological Magazine 131: $269-272$.

- 2000. A reconsideration of Wattieza Stockmans (here attributed to Cladoxylopsida) based on a new species from the Devonian of Venezuela. - Review of Palaeobotany and Palynology 112: $125-146$.

Berry, C. M. \& Edwards, D. 1994. New data on the morphology and anatomy of the Devonian zosterophyll Serrulacaulis Hueber and Banks from Venezuela. - Review of Palaeobotany and Palynology 81: 141-150.

- 1995. New species of the Devonian lycophyte Colpodexylon from the Devonian of Venezuela. - Palaeontographica B 137: 59-74.

- 1996a. The herbaceous lycophyte genus Haskinsia Grierson and Banks from the Devonian of western Venezuela, with observations on the leaf morphology and fertile specimens. - Botanical Journal of the Linnean Society 122: $103-122$

- 1996b. Anapaula moodyi gen. et sp. nov., a probable iridopteridalean compression fossil from the Devonian of Venezuela. - Review of Palaeobotany and Palynology 93: $127-145$.

- 1997. A new species of the lycopsid Gilboaphyton Arnold from the Devonian of Venezuela and New York State, with a revision of the closely related genus Archaeosigillaria Kidson. - Review of Palaeobotany and Palynology 96: $47-70$.

Berry, C. M. \& Stein, W. E. 2000. A new iridopteridalean from the Devonian of Venezuela. - International Journal of Plant Science 161: 807-827.

Berry, C. M., Casas, J. E. \& Moody, J. M. 1993. Diverse Devonian plant fossil assemblages from Venezuela. - Documents de Laboratoires de Geologie de Lyon 125: 29-42.
Berry, C., Casas, J., Moody, J. M. \& Young, G. 1997. Síntesis estratigráfica y paleontológica de la Formación Campo Chico (Devónico medio-superior), Sierra de Perijá. Memorias del VIII Congreso Geológico Venezolano, Sociedad Venezolana de Geólogos 1: 125-132.

Berry, C. M., Morel, E., Mojica, J. \& Villarroel, C. 2000. Devonian plants from Colombia, with discussion of their geological and palaeogeographical context. - Geological Magazine 137: 257-268.

Bjerstedt, T. W. 1987. Latest Devonian-earliest Mississippian nearshore trace-fossil assemblages from West Virginia, Pennsylvania, and Maryland. - Journal of Paleontology 61: $865-889$.

Bonaparte, C. L. 1838. Synopsis vertebratorum systematis. Nuovi Annali delle Scienze Naturali, Bologna 11 $105-133$.

Boucot, A. 1975. Evolution and extinction rate controls. 427 pp. Elsevier, Amsterdam.

Bowen, J. M. 1972. Estratigrafía del pre-Cretáceo en la parte Norte de la Sierra de Perijá. - Memoria IV Congreso Geológico Venezolano II: 729-760.

Campbell, K. S. W. \& Barwick, R. E. 1987. Paleozoic lungfishes - a review. - Journal of Morphology, Supplement 1 (1986): 93-131.

Casas, J. E., Moody, J. M. \& Berry, C. M. 1990. Estudio paleontológico de la Formacion Campo Chico (Devónico Medio-Superior). - Informes Técnicos, IT-10905, Maraven S.A., Caracas, 6 pp., 13 figs.

Casas, J. E., Moody, J. M. \& Young, G. C. 1992. Vertebrados fósiles de la Formación Campo Chico (Devónico MedioSuperior). - Reporte Maraven EPC-12.972. Maraven, Caracas, 7 pp., 13 figs.

Cloutier, R. 1996a. Dipnoi (Akinetia: Sarcopterygii). In Schultze, H.-P. \& Cloutier, R. (eds), Devonian Fishes and Plants of Miguasha, Quebec, Canada: 198-226, Verlag Dr Friedrich Pfeil, Munich.

- 1996b. The primitive actinistian Miguashaia bureaui Schultze (Sarcopterygii). In Schultze, H.-P. \& Cloutier, R. (eds), Devonian fishes and plants of Miguasha, Quebec, Canada: 227-247, Verlag Dr Friedrich Pfeil, Munich.

Cloutier, R. \& Schultze, H.-P. 1996. Porolepiform fishes (Sarcopterygii). In Schultze, H.-P. \& Cloutier, R. (eds), Devonian fishes and plants of Miguasha, Quebec, Canada: 248-270, Verlag Dr Friedrich Pfeil, Munich.

Cloutier, R. Loboziak, S., Candilier, A.-M. \& Blieck, A. 1996. Biostratigraphy of the Upper Devonian Escuminac Formation, eastern Quebec, Canada: a comparative study based on miospores and fishes. - Review of Palaeobotany and Palynology 93: 191-215.

Cope, E. D. 1871. Observations on the systematic relations of the fishes. - American Naturalist 5: 579-593.

- 1885. The position of Pterichthys in the system. - American Naturalist 19: 289-291.

- 1886. An interesting connecting genus of Chordata. American Naturalist 20: 1027-1031.

- 1889. Synopsis of the families of Vertebrata. - American Naturalist 23: 849-877.

Dalziel, I. W. D., Dalla Salda, L. H. \& Gahagan, L. M. 1994 Paleozoic Laurentia-Gondwana interaction and the origin of the Appalachian-Andean mountain system. - Geological Society of America Bulletin 106: 243-252.

de Carvalho, M. \& Moody, J. 2000. A Middle Devonian trilobite assemblage from Venezuela. - American Museum Novitates 3292: 1-15.

Denison, R. H. 1974. The structure and evolution of teeth in lungfishes. - Fieldiana Geology 33: 31-58.

- 1978. Placodermi. In Schultze, H.-P. (ed.), Handbook of Paleoichthyology, volume 2, 128 pp. Gustav Fischer Verlag, Stuttgart.

- 1979. Acanthodii. In Schultze, H.-P. (ed.), Handbook of Paleoichthyology, volume 5, $62 \mathrm{pp}$. Gustav Fischer Verlag, Stuttgart.

Diaz-Martínez, E., Suárez-Riglos, M., Lelievre, H. \& Janvier, P. 1996. Première découverte d'un arthrodire (Placoder- 
mi, Vertebrata) dans le Dévonien d'Amérique du Sud. Comptes Rendus de l'Academie des Sciences, Paris, sér. 2a 323: 349-356.

Edwards, D. \& Benedetto, J. L. 1985. Two new species of herbaceous lycopods from the Devonian of Venezuela with comments on their taxonomy. - Palaeontology 28 : 599-618.

Eichwald, E. I. 1840. Die Thier- und Pflanzenseste des alten rothen Sandsteins und Bergkalks im Novgorodschen Gouvernement. - Bulletin de l'Académie (impériale) des Sciences de Saint-Petersbourg 7: 78-91.

Eldredge, N. \& Ormiston, A. R. 1979. Biogeography of Silurian and Devonian trilobites of the Malvinokaffric Realm. In Gray, J. \& Boucot, A. J. (eds), Historical Biogeography, plate tectonics, and the changing environment: 147-167, Corvallis, Oregon State Univ. Press.

Forero, A. 1990. The basement of the Eastern Cordillera, Columbia: an allochthonous terrane in northwestern South America. - Journal of South American Earth Sciences 3: 141-151.

Forster-Cooper, C. 1937. The Middle Devonian fish fauna of Achanarras. - Transactions of the Royal Society of Edinburgh 59: 223-239.

Fox, R. C., Campbell, K. S. W., Barwick, R. E. \& Long, J. A. 1995. A new osteolepiform fish from the Lower Carboniferous Raymond Formation, Drummond Basin, Queensland. - Memoirs of the Queensland Museum 38: 97-221.

Frenguelli, J. 1951. Floras devónicas de la Precordillera de San Juan: nota preliminar. - Revista Associación geológica Argentina 4: 83-94.

Frey, R. W. 1978. Behavioral and ecological implications of trace fossils. In Trace fossil concepts. - Society of Economic Paleontologists and Mineralogists, Oklahoma City: Short Course 5: 133-183.

Gagnier, P.-Y., Turner, S., Friman, L., Suárez-Riglos, M. \& Janvier, P. 1988. The Devonian vertebrate and mollusc fauna from Seripona (Dept. of Chuquisaca, Bolivia). Neues Jahrbuch für Geologie und Paläontologie, Abhandlungen 176: $269-297$.

González de Juana, C., Iturralde de Arozena, J. M., \& Picard Cadillat, X. 1980. Geología de Venezuela y de sus Cuencas Petrolíferas. - Foninves, Caracas, 2 vols., 1030 pp.

Goujet, D., Janvier, P. \& Racheboeuf, P. 1993. Placoderm and chondrichthyan remains from the Middle Devonian of Chacoma, Bolivia. - Neues Jahrbuch für Geologie und Paläontologie, Monatschefte 1993: 355-372.

Goujet, D., Janvier, P. \& Suárez-Riglos, M. 1984. Devonian vertebrates from South America. - Nature 312: 311.

- 1985. Un nouveau rhenanide (Vertebrata, Placodermi) de la formacion de Belen (Devonien moyen), Bolivie. - Annales de Paléontologie (Vertébres-Invertébres) 71: 35-53.

Gross, W. 1931. Asterolepis ornata Eichw. und das AntiarchiProblem. - Palaeontographica A 75: 1-62.

- 1932. Die Arthrodira Wildungens. - Geologische und Paläontologische Abhandlungen (Neue folge) 19: 1-61.

- 1933a. Die unterdevonischen Fische und Gigantostraken von Overath. - Abhandlungen der Preussischen geologischen Landesanstalt 145: $41-77$.

- 1933b. Die Fische des Baltischen Devons. - Palaeontographica A 79: 1-74.

- 1941. Die Bothriolepis-Arten der cellulosa-Mergel Lettlands. - Kungliga Svenska Vetenskapsakademiens Handlinger (3) 19: 1-79.

- 1956. Uber Crossopterygier und Dipnoer aus dem baltischen Oberdevon im Zusammenhang einer vergleichenden Untersuchung des Porenkanalsystems palaozoischer Agnathen und Fische. - Kungliga Svenska Vetenskapsakademiens Handlinger (4) 5: 1-140.

Harvey, C. 1999. Middle and Upper Devonian palynology of the Sierra de Perijá, western Venezuela. - Palaeontological Association Newsletter (abstracts) 42: 17-18.

- 2001. Palynology and Coal Analysis of the Devonian Campo Chico Formation, western Venezuela. - (Unpublished $\mathrm{Ph} . \mathrm{D}$. thesis, University of Sheffield).
Hemmings, S. K. 1978. The Old Red Sandstone antiarchs of Scotland: Pterichthyodes and Microbrachius. - Palaeontographical Society (Monograph) 131: 1-64.

Higgs, K. T., MacCarthy, I. A. J. \& O'Brien, M. M. 2000. A mid-Frasnian marine incursion into the southern part of the Munster Basin: evidence from the Foilcoagh Bay Beds, Sherkin Formation, SW County Cork, Ireland. In Friend, P. F. \& Williams, B. P. J. (eds), New Perspectives on the Old Red Sandstone. - Geological Society of London Special Publication 180: 319-332.

Hunicken, M. A. 1992. Lung-fishes (Dipnoi) in the Gondwanic Bajo de Veliz Formation (Upper Carboniferous), San Luis Province, Argentina. - 2nd Latin American Conodont Symposium LACON-II, 8-16 November 1992. Abstracts volume: 104, Academia Nacional de Ceincias Cordoba, Argentina.

Huxley, T. H. 1880. On the application of the laws of evolution to the arrangement of the Vertebrata and more particularly the Mammalia. - Proceedings of the Zoological Society of London 1880: $649-662$.

Janvier, P. 1976. Description des restes d'elasmobranches (Pisces) du Devonien moyen de Bolivie. - Palaeovertebrata 7-IV: $126-132$.

- 1987. Les vertébrés siluriens et dévoniens de Bolivie: remarques particulieres sure les Chondrichthyens. - 40 Congreso Latinoamericano de Paleontología, Santa Cruz A: $159-178$.

1996. Early Vertebrates. 393 pp. Clarendon Press, Oxford.

Janvier, P. \& Dingerkus, G. 1991. Le synarcual de Pucapampella Janvier \& Suárez-Riglos: une preuve de l'existence d'Holocephales des le Devonien moyen. - Comptes Rendus de l'Academie des Sciences, Paris 312: 549-552.

Janvier, P. \& Melo, J. H. G. 1987. Late Devonian actinopterygian scales from the Amazon Basin, northwestern Brazil. - Annais da Academia Brasileira de Ciências 59: $213-218$

- 1988. Acanthodian fish remains from the Upper Silurian or Lower Devonian of the Amazon Basin, Brazil. - Palaeontology 31: 771-777.

- 1992. New acanthodian and chondrichthyan remains from the Lower and Middle Devonian of Brazil. - Neues Jahrbuch für Geologie und Paläontologie, Monatschefte 1992: 193-206.

Janvier, P. \& Suárez-Riglos, M. 1986. The Silurian and Devonian vertebrates of Bolivia. - Bulletin de l' Institute Francais d'Etudes Andines, Lima 15: 73-114.

Janvier, P. \& Villarroel, C. 2000. Devonian vertebrates from Colombia. - Palaeontology 43: 729-763.

Jarvik, E. 1948. On the morphology and taxonomy of the Middle Devonian osteolepid fishes of Scotland. - Kungliga Svenska VetenskapAkademiens Handlingar, Stockholm, 3(25), 1: 1-301.

Johanson, Z. 1997. New Remigolepis (Placodermi; Antiarchi) from Canowindra, New South Wales, Australia. - Geological Magazine 134: 813-846.

- 1998. The Upper Devonian fish Bothriolepis (Placodermi: Antiarchi) from near Canowindra, New South Wales, Australia. - Records of the Australian Museum 50: $315-348$.

Johanson, Z. \& Young, G. C. 1999. New Bothriolepis (Antiarchi: Placodermi) from the Braidwood region, New South Wales, Australia (Frasnian). - Records of the Western Australian Museum Supplement 57: 55-75.

Jones, R. K. \& Turner, S. 2000. Late Devonian fauna from the Columbine Sandstone (Coffee Hill Member), Gap Creek, central New South Wales. - Courier Forschungsinstitut Senckenberg 223: 523-541.

Karatajûte-Talimaa, V. N. 1963. Genus Asterolepis from the Devonian of the Russian Platform. In Grigelis A. \& Karatajûte-Talimaa, V. (eds), The data of geology of the Lithuania: 65-223, Geologic and Geographic Institute of the Academy of Sciences of the Lithuanian SSR, Vilnius, (Russian with English summary). 
Katzer, F. 1897. Das Amazonas-Devon und seine Beziehung zu den anderen Devongebieten der Erde. Sitzungsberichte der Königlich böhmischen Gesellschaft der Wissenschaften (Mathematische-naturwissenschaftliche Klasse) 46: 1-50.

Kegel, W. 1953. Contribuçao para o estudio do Devoniano de bacia do Parnaiba. - Boletim da Divisião de Geologia e Meralogia, 141: 1-48.

Kent, D. V. \& Van der Voo, R. 1990. Palaeozoic palaeogeography from palaeomagnetism of the Atlantic-bordering continents. - Geological Society of London, Memoir 12: $49-56$.

Lelièvre H., Janvier, P. \& Blieck, A. 1993. Silurian-Devonian vertebrate biostratigraphy of western Gondwana and related terranes (South America, Africa, Armorica-Bohemia, Middle East). In Long, J. A. (ed.), Palaeozoic Vertebrate Biostratigraphy and Biogeography: 139-173, Belhaven Press, London.

Li, Z. X., Powell, C. McA. \& Trench, A. 1993. Palaeozoic global reconstructions: In Long, J. A. (ed.), Palaeozoic Vertebrate Biostratigraphy and Biogeography: 25-53, Belhaven Press, London.

Liddle, R. A., Harris, G. \& Wells, J. W. 1943. The Rio Cachiri section in the Sierra de Perijá, Venezuela. - Bulletin of American Paleontology 27: 273-365.

Long, J. A. 1984. New phyllolepids from Victoria and the relationships of the Group. - Proceedings of the Linnean Society of New South Wales 97: 87-93.

- 1987. A redescription of the lungfish Eoctenodus Hills 1929 , with reassessment of other Australian records of the genus Dipterus Sedgewick \& Murchison 1828. - Records of the Western Australian Museum 13: 297-314.

- 1997. Ptyctodontid fishes (Vertebrata, Placodermi) from the Late Devonian Gogo Formation, Western Australia, with a revision of the European genus Ctenurella Ørvig 1960. - Geodiversitas 19: 515-555.

- 1999. A new genus of fossil coelacanth (Osteichthyes: Coelacanthiformes) from the Middle Devonian of southeastern Australia. - Records of the Western Australian Museum, Supplement 57: 37-53.

Long, J. A. \& Campbell, K. S. W. 1985. A new lungfish from the Lower Carboniferous of Victoria. - Proceedings of the Royal Society of Victoria 107: 263-308.

Long, J. A. \& Young, G. C. 1995. New sharks from the Middle-Late Devonian Aztec Siltstone, southern Victoria Land, Antarctica. - Records of the Western Australian Museum 17: 287-308.

Long, J. A., Anderson, M. E., Gess, R. W. \& Hiller, N. 1997. New placoderm fishes from the Late Devonian of South Africa. - Journal of Vertebrate Paleontology 17: 253-268.

McCoy, F. 1848. On some new fossil fishes of the Carboniferous period. - Annals and Magazine of Natural History 2: $1-10$.

Maisey, J. G. 1981. Studies on the Paleozoic selachian genus Ctenacanthus Agassiz No. 1. Historical review and revised diagnosis of Ctenacanthus, with a list of referred taxa. American Museum Novitates 2718: 1-22.

- 1982. Studies on the Paleozoic selachian genus Ctenacanthus Agassiz: No. 2. Bythiacanthus St. John and Worthen, Amelacanthus, new genus, Euemacanthus St. John and Worthen, Sphenacanthus Agassiz, and Wodnika Münster. - American Museum Novitates 2722: 1-24.

- 1984. Studies on the Paleozoic selachian genus Ctenacanthus Agassiz No. 3. Nominal species referred to Ctenacanthus. - American Museum Novitates 2774: 1-20.

- 2001. A primitive chondrichthyan braincase from the Middle Devonian of Bolivia. In Ahlberg, P.E. (ed.), Major Events in Early Vertebrate Evolution. - Systematics Association Special Volume 61: 263-288.

Maze, W. B. 1984. Jurassic La Quinta Formation in the Sierra de Perijá, northwestern Venezuela: Geology and tectonic environment of red beds and volcanic rocks. - Geological Society of America, Memoir 162: 263-282.
Mcloughlin, S. \& Long, J. A. 1994. New records of Devonian plants from southern Victoria Land, Antarctica. - Geological Magazine 131: 81-90.

Meyerhoff, A. A., Boucot, A. J., Hull, D. M. \& Dickins, J. M. 1996. Phanerozoic faunal and floral realms of the Earth: the intercalary relations of the Malvinokaffric and Gondwana faunal realms with the Tethyan faunal realm. Geological Society of America Memoir 189: 1-69.

Miles, R. S. 1968. The Old Red Sandstone antiarchs of Scotland. Family Bothriolepididae. - Palaeontographical Society (Monograph) 122: $1-130$.

- 1977. Dipnoan (lungfish) skulls and the relationships of the group: a study based on new species from the Devonian of Australia. - Zoological Journal of the Linnean Society 61: $1-328$.

Mojica, J. \& Villarroel, C. 1984. Contribución al conocimiento de las unidades paleozoicas del área del Floresta (Cordillera Oriental colombiana; Departamento de Boyacá) y en especial de la Formación Cuche. - Geología Colombiana 13: 55-80.

- 1990. Sobre la distribución y facies del Paleozoico Inferior sedimentario en el extremo NW de Suramérica. Geología Colombiana 17: 219-226.

Müller, J. 1845. Über den Bau und die Grenzen der Ganoiden, and über das naturliche System der Fische. - Berlin Akademie Wissenschaften Berlin 1844: 67-85.

Newberry, J. S. 1857. Fossil fishes from the Devonian of Ohio. - Proceedings of the National Institute for the Promotion of Science 1: 119-126.

Odreman, O. E. \& Medina, C. J. 1984. Vertebrados fósiles de Venezuela. Secuencia, relaciones con otros paises de América del Sur. - Ministerio de Energía y Minas. Cuardernos Geológicos 1: $60-86$.

Oliver, W. A. \& Pedder, A. E. H. 1989. Origins, migrations, and extinctions of Devonian Rugosa on the North American Plate. - Association of Australasian Paleontologists, Memoir 8: 231-237.

Ørvig, T. 1957. Notes on some of acanthodians, arthrodires, crossopterygians, ganoids and dipnoans in the Upper Middle Devonian Calcareous Flags (oberer Plattenkalk) of the Bergisch-Paffrath Trough. (Part. I). - Paläontologische Zeitschrift 34: 295-335.

- 1961. New finds of acanthodians, arthrodires, crossopterygians, ganoids, and dipnoans in the Upper Middle Devonian calcareous flags (Oberer Plattenkalk) of the Bergisch - Paffrath Trough (Part 2). - Paläontologische Zeitschrift 35: 10-27.

- 1969. Cosmine and cosmine growth. - Lethaia 2 $241-260$.

Owen, R. 1846. Lecture on the comparative anatomy and physiology of the vertebrate animals, delivered at the Royal College of Surgeons of England. I, Fishes. Longman, Brown, Green \& Longmans, London, 308 pp.

Pridmore, P. \& Barwick, R. E. 1993. Post-cranial morphologies of the Late Devonian dipnoans Griphognathus and Chirodipterus and locomotor implications. - Association of Australasian Paleontologists, Memoir 15: 161-182.

Reed, J. W. 1985. Devonian dipnoans from Red Hill, Nevada. - Journal of Paleontology 59: 1181-1193.

Restrepo, J. J. \& Toussaint, J. 1988. Terranes and continental accretion in the Colombian Andes. - Episodes 11: 189-193.

Richardson, J. B. \& McGregor, D. C. 1986. Silurian and Devonian spore zones of the Old Red Sandstone Continent and adjacent regions. - Geological Survey of Canada, Bulletin 364: 1-79.

Ritchie, A. 1984. A new placoderm, Placolepis gen. nov. (Phyllolepidae) from the Late Devonian of New South Wales, Australia. - Proceedings of the Linnean Society of New South Wales 107: 321-353.

Ritchie, A., Wang, S. T., Young, G. C. \& Zhang, G. R. 1992 The Sinolepidae, a family of antiarchs (placoderm fishes) from the Devonian of South China and eastern Australia - Records of the Australian Museum 44: 319-370. 
Romer, A. S. 1955. Herpetichthyes, Amphibioidei, Choanichthyes or Sarcopterygii? - Nature, Lond. 176: 126-127.

Rosen, D. E. 1974. Phylogeny and zoogeography of salmoniform fishes. - Bulletin of the American Museum of Natural History 153: 265-326.

Santos, R. S. 1961. Peixes fósseis do Devoniano Inferior de Picos, Estado do Piaui. - Anais da Academia brasileira de Ciências 33: 32.

Schmidt, W. E. 1938. Fósiles paleozoicos de la Cordillera Oriental de Colombia (Cordillera de Bogotá). In Estudios geológicos y paleontológicos sobre la Cordillera Oriental de Colombia). Parte segunda - Republica de Colombia, Ministerio de Industrias y Trabajo. Departamento de Minas y Petróleos, 1-15, pl. 1-2.

Schultze, H.-P. 1969. Griphognathus Gross, ein langschnauziger Dipnoer aus dem Oberdevon von Bergisch-Gladbach (Rheinisches Schiefergebirge) und von Lettland. - Geologie und Palaeontologie Marburg 3: 21-79.

- 1991. Lungfish from the El Molino (Late Cretaceous) and Santa Lucia (Early Paleocene) Formations in southcentral Bolivia. In Suárez-Soruco, R. (Ed.) Fósiles y Facies de Bolivia - Vol. 1 Vertebrados. Revista Técnica de YPFB 12: $441-448$.

- 1992. A new long-headed dipnoan (Osteichthyes) from the Middle Devonian of Iowa, USA. - Journal of Vertebrate Paleontology 12: 42-58.

- 1994. Osteichthyes: Sarcopterygii. In Benton, M.J. (ed.). The Fossil Record 2: 657-663, Chapman \& Hall, London.

- 1996. Walter R. Gross, a palaeontologist in the turmoil of $20^{\text {th }}$ Century Europe. - Modern Geology 20: 209-233.

Schultze, H.-P. \& Cloutier, R. 1996. Comparison of the Escuminac Formation ichthyofauna with other late Givetian/ early Frasnian ichthyofaunas. In Schultze, H.-P. \& Cloutier, R. (eds). Devonian Fishes and Plants of Miguasha, Quebec, Canada: 348-368, Verlag Dr Friedrich Pfeil, Munich.

Scrutton, C. T. 1973. Palaeozoic coral faunas from Venezuela, II: Devonian and Carboniferous corals from the Sierra de Perijá. - Bulletin of the British Museum (Natural History), Geology 23: 223-281.

Seilacher, A. 1967. Bathymetry of trace fossils. - Marine Geology 5: 413-428.

- 1978. Use of trace fossils for recognizing depositional environments. In Trace fossil concepts. - Society of Economic Paleontologists and Mineralogists, Oklahoma City: Short Course 5: 185-201

Soler-Gijón, R. 1997. Euselachian sharks from the Late Carboniferous of the Puertollano Basin, Spain: biostratigraphic and palaeoenvironmental implications. - Modern Geology 21: 137-169.

Stensiö, E. A. 1931. Upper Devonian vertebrates from East Greenland, collected by the Danish Greenland Expedition in 1929 and 1930. - Meddelelser om Grønland 86: $1-212$.

- 1934. On the Placodermi of the Upper Devonian of East Greenland. I. Phyllolepida and Arthrodira. - Meddelelser om Grønland 97(1): 1-58.

- 1939. On the Placodermi of the Upper Devonian of East Greenland. Second supplement to part I. - Meddelelser om Grønland 97(3): 1-33.

- 1948. On the Placodermi of the Upper Devonian of East Greenland. 2. Antiarchi: subfamily Bothriolepinae. With an attempt at a revision of the previous described species of that family. - Meddelelser om Grønland 139: 1-622.

Streel, M., Higgs, K., Loboziak, S., Riegel, W. \& Steemans, P. 1987. Spore stratigraphy and correlation with faunas and floras in the type marine Devonian of the Ardenne-Rhenish regions. - Review of Palaeobotany and Palynology 50: $211-229$

Sutton, F. A. 1946. Geology of the Maracaibo Basin, Venezuela. - Bulletin of the American Association of Petroleum Geology 30: 1621-1741.
Tait, J., Schatz, M., Bachtadse, V. \& Soffel, H. 2000. Palaeomagnetism and Palaeozoic paleogeography of Gondwana and European terranes. In Franke, W., Haak, V. Oncken, O. \& Tanner, D. (eds.), Orogenic Processes: Quantification and Modelling in the Variscan Belt. - Geological Society of London, Special Publication 179: 21-34.

Tasch, P. 1987. Fossil Conchostraca of the Southern Hemisphere and continental drift. Paleontology, biostratigraphy, and dispersal. - Geological Society of America, Memoir 165: 1-290.

Thery, J. M. 1982. Constitution du nord-ouest du continent sud-americain avant les tectoniques andines. - Ph.D thesis (unpublished), University of Bordeaux III.

Thomson, K. S. 1964. Revised generic diagnoses of the fossil fishes Megalichthys and Ectosteorhachis (family Osteolepidae). - Bulletin of the Museum of Comparative Zoology, Harvard University 131: $283-311$.

Upeniece, I. \& Upenieks, J. 1992. Young Upper Devonian antiarch (Asterolepis) individuals from the Lode quarry, Latvia. In Mark-Kurik, E. (ed.). Fossil Fishes as Living Animals: 167-176, Academy of Sciences of Estonia, Tallinn.

Van Der Voo, R. 1988. Paleozoic paleogeography of North America, Gondwana, and displaced terranes: comparisons of paleomagnetism with paleoclimatology and biogeographical patterns. - Geological Society of America Bulletin 100: $311-324$.

- 1993. Paleomagnetism of the Atlantic, Tethys and Iapetus oceans: 411 pp., Cambridge University Press, Cambridge.

Warren, A., Currie, B. P., Burrow, C. \& Turner, S. 2000. A redescription and reinterpretation of Gyracanthides murrayi Woodward 1906 (Acanthodii, Gyracanthidae) from the Lower Carboniferous of the Mansfield Basin, Victoria, Australia. - Journal of Vertebrate Paleontology 20: $225-242$

Weisbord, N. E. 1926. Venezuelan Devonian fossils. - Bulletin of American Paleontology 11: 221-272.

Wells, J. W. 1940. A new ichthyodorulite from the Geneseo Shale (Devonian of New York). - The American Midland Naturalist 24: 411-413.

Werdelin, L. \& Long, J. A. 1986. Allometry in Bothriolepis canadensis Whiteaves (Placodermi, Antiarcha) and its significance to antiarch evolution. - Lethaia 19: 161-169.

White, E. I. 1965. The head of Dipterus valenciennesi Sedgwick \& Murchison. - Bulletin of the British Museum (Natural History), Geology, 11: 1-44.

Woodward, A. S. 1891. Catalogue of Fossil Fishes. Part 2: 1-567. British Museum (Natural History), London.

Young, G. C. 1981. Biogeography of Devonian vertebrates. Alcheringa 5: 225-243.

- 1982. Devonian sharks from south-eastern Australia and Antarctica. - Palaeontology 25: 817-843.

- 1983. A new antiarchan fish (Placodermi) from the Late Devonian of southeastern Australia. - BMR Journal of Australian Geology \& Geophysics 8: 71-81.

- 1984a. Comments on the phylogeny and biogeography of antiarchs (Devonian placoderm fishes), and the use of fossils in biogeography. - Proceedings of the Linnean Society of New South Wales 107: 443-473.

- 1984b. Reconstruction of the jaws and braincase in the Devonian placoderm fish Bothriolepis. - Palaeontology 27: $625-661$.

- 1985. New discoveries of Devonian vertebrates from the Amadeus Basin, central Australia. - BMR Journal of Australian Geology \& Geophysics 9: 239-254.

- 1988a. Antiarchs (placoderm fishes) from the Devonian Aztec Siltstone, southern Victoria Land, Antarctica. Palaeontographica A 202: 1-125.

- 1988b. New occurrences of phyllolepid placoderms from the Devonian of central Australia. - BMR Journal of Australian Geology \& Geophysics 10: 363-376.

- 1989. The Aztec fish fauna of southern Victoria Land evolutionary and biogeographic significance. In Crame, A. (ed.), Origin and Evolution of the Antarctic Biota. - 
Geological Society of London, Special Publication 47: $43-62$.

- 1990. Devonian vertebrate distribution patterns, and cladistic analysis of palaeogeographic hypotheses. - Geological Society of London, Memoir 12: 243-255.

- 1992. Description of the fish spine. In Webers, G.F., Craddock, C., \& Splettstoesser, J.F. (eds.), Geology and Paleontology of the Ellsworth Mountains, West Antarctica. - Geological Society of America, Memoir 170: 273-278.

- 1993a. Middle Palaeozoic macrovertebrate biostratigraphy of eastern Gondwana, In Long, J. A. (ed.), Palaeozoic Vertebrate Biostratigraphy and Biogeography: 208-251, Belhaven Press, London.

- 1993b. Vertebrate faunal provinces in the Middle Palaeozoic. In Long, J. A. (ed.), Palaeozoic Vertebrate Biostratigraphy and Biogeography: 293-323, Belhaven Press, London.

- in press. North Gondwana mid-Palaeozoic connections with Euramerica and Asia; Devonian vertebrate evidence. - Courier Forschungsinstitut Senckenberg.

Young, G. C. \& Gorter, J. D. 1981. A new fish fauna of Middle Devonian age from the Taemas/Wee Jasper region of New South Wales. - Bureau of Mineral Resources, Geology and Geophysics (Australia) Bulletin 209: 83-147.

Young, G. C. \& Zhang, G.-R. 1992. Structure and function of the pectoral joint and operculum in antiarchs, Devonian placoderm fishes. - Palaeontology 35: 443-464.

- 1996. New information on the morphology of yunnanolepid antiarchs (placoderm fishes) from the Early Devonian of south China. - Journal of Vertebrate Paleontology 16: 623-641.

Young, G. C., Long, J. A. \& Ritchie A. 1992. Crossopterygian fishes from the Devonian of Antarctica: systematics, relationships and biogeographic significance. - Records of the Australian Museum, Supplement 14: 1-77.

Young, G. C., Long, J. A. \& Turner, S. 1993. Faunal lists of Eastern Gondwana Devonian macrovertebrate assemblages. In Long, J. A. (ed.), Palaeozoic Vertebrate Biostratigraphy and Biogeography: 246-251, Belhaven Press, London.

Young, G. C., Long, J. A. \& Burrow, C. 2000a. Devonian vertebrates, In Wright, A. T., Young, G. C., Talent, J. A. \& Laurie, J. (eds), Palaeobiogeography of Australasian Faunas and Floras. - Association of Australasian Palaeontologists, Memoir 23: 209-218.

Young, G. C., Moody, J. \& Casas, J. 2000b. New discoveries of Devonian vertebrates from South America, and implications for Gondwana-Euramerica contact. - Comptes Rendus de l'Académie des Sciences, Paris 331: 755-761.

Young, V. T. 1986. Early Devonian fish material from the Horlick Formation, Ohio Range Antarctica. - Alcheringa 10: $35-44$.

Zhang G.-R. 1978. The antiarchs from the Early Devonian of Yunnan. - Vertebrata PalAsiatica 16: 147-186 (Chinese with English summary).

Zhang, G. R. \& Young, G. C. 1992. A new antiarch (placoderm fish) from the Early Devonian of South China. Alcheringa 16: 219-240.

Zhu, M. 1996. The phylogeny of the Antiarcha (Placodermi, Pisces), with the description of Early Devonian antiarchs from Qujing, Yunnan, China. - Bulletin du Museum national d'Histoire naturelle, Paris $(4, C)$ 18: $233-347$.

Zidek, J. 1981. Machaeracanthus Newberry (Acanthodii: Ischnacanthiformes) - morphology and systematic position. - Neues Jahrbuch für Geologie und Paläontologie, Monatshefte 1981: 742-748.

\section{Appendix}

Complete specimen listing for Devonian fish collection from Sierra de Perijá, Venezuela. Original field determinations are listed, except where updated by further preparation or study. Locality numbers are shown in Fig. 1. MBLUZ P- is the registered number in the Museo de Biología, Universidad del Zulia, Maracaibo. MB. f. is the registered number in the collection of the Institut für Paläontologie, Museum für Naturkunde, Berlin, assigned to replicas of cast specimens, or to offcut pieces from the associated MBLUZ number.

\begin{tabular}{|c|c|c|c|}
\hline $\begin{array}{l}\text { MBLUZ } \\
\text { P-No. }\end{array}$ & Loc. No. & $\begin{array}{l}\text { MB. f. No. } \\
\text { [specimen] }\end{array}$ & Determination \\
\hline 5 & 118 & f.7531 & ?antarctilamnid spine impression \\
\hline 6 & 118 & f. 7532 & ?antarctilamnid spine impression (incomplete) \\
\hline 7 & 118 & f. 7533 & ?antarctilamnid spine impression (incomplete) \\
\hline 43 & 139 & & Bothriolepis La plate \\
\hline 44 & 139 & & antiarch bone \\
\hline 45 & 139 & & antiarch bone \\
\hline 52 & 139 & & Bothriolepis AMD plate \\
\hline 66 & 139 & & Scale, isolated, incomplete \\
\hline 67 & 139 & & antiarch bones \\
\hline 68 & 139 & & bone, in matrix, incomplete \\
\hline 69 & 139 & & osteolepid scale, incomplete \\
\hline 70 & 139 & & antiarch bone, in matrix, incomplete \\
\hline 71 & 139 & & antiarch fin bone \\
\hline 91 & 139 & & osteolepid scale \\
\hline 92 & 139 & & osteolepid scale \\
\hline 93 & 139 & & osteolepid scale \\
\hline 94 & 139 & & Bothriolepis right $\mathrm{Cd} 1$ plate \\
\hline 95 & 139 & & Bothriolepis fin bone \\
\hline
\end{tabular}




\begin{tabular}{|c|c|c|c|}
\hline $\begin{array}{l}\text { MBLUZ } \\
\text { P-No. }\end{array}$ & Loc. No. & $\begin{array}{l}\text { MB. f. No. } \\
\text { [specimen] }\end{array}$ & Determination \\
\hline 96 & 139 & & Bothriolepis fin bone, incomplete, with articulation \\
\hline 99 & 139 & & crossopterygian scale \\
\hline 102 & 139 & & Bothriolepis, Nu bone, incomplete \\
\hline 103 & 139 & & Bothriolepis, ?left PNu and PM plates \\
\hline 104 & 139 & & osteolepid tooth \\
\hline 105 & 139 & & Bothriolepis, ADL plate, left \\
\hline 106 & 139 & & Bothriolepis, PVL plate, left \\
\hline 107 & 139 & & osteolepid scale \\
\hline 108 & 139 & f. 7534 & osteolepid ?bones, ?clavicle \\
\hline 109 & 139 & f. 7535 & osteichthyan scales, round, cosmoid \\
\hline 110 & 139 & & antiarch plates and osteolepid scales \\
\hline 111 & 139 & & Bothriolepis, various plates incl. $\mathrm{Cd} / \mathrm{Cv}$ from dist.seg. \\
\hline 112 & 139 & & antiarch plate with coarse ornament \\
\hline 113 & 139 & & Venezuelepis, Cd1 plate \\
\hline 114 & 139 & & Bothriolepis, La, AMD, pect fin plates \\
\hline 115 & 139 & & Venezuelepis, left $\mathrm{ADL}(?)$ plate \\
\hline 116 & 139 & & small antiarch bones \\
\hline 117 & 139 & & small antiarch bones \\
\hline 118 & 139 & f.7536 & round osteichthyan scale \\
\hline 119 & 139 & & Bothriolepis, MxL, AMD, PMD \\
\hline 120 & 139 & f.7537 & round osteichthyan scale \\
\hline 121 & 139 & & round osteichthyan scale \\
\hline 122 & 139 & f.7538 & osteolepid (?) median scale \\
\hline 123 & 139 & & osteolepid (?) cosmoid bones \\
\hline 124 & 139 & & cosmoid bones, small dipnoan tooth plate \\
\hline 125 & 139 & & antiarch plates $\&$ cosmoid bones \\
\hline 126 & 139 & & antiarch plates \& cosmoid bones \\
\hline 127 & 139 & & Bothriolepis, Cv2 plate \\
\hline 128 & 139 & f. 7539 & striated osteichthyan scale \\
\hline 129 & 118 & f. 7540 & phyllolepid plate impression, incomplete \\
\hline 130 & 118 & f. 7541 & phyllolepid plate impression, incomplete \\
\hline 131 & 118 & f. 7542 & indeterminate ?placoderm impressions, incomplete \\
\hline 132 & 118 & f. 7543 & indeterminate ?placoderm impressions, incomplete \\
\hline 133 & 118 & f. 7544 & Machaeracanthus spine impressions \\
\hline 134 & 121 & f. 7545 & ?antarctilamnid spine impression, incomplete \\
\hline 135 & 118 & f. 7546 & ?antarctilamnid spine impression, incomplete \\
\hline 136 & 139 & & Bothriolepis, ADL plate, left, incomplete \\
\hline 137 & 139 & f. 7547 & Venezuelepis PrM (?) plate, osteolepid tooth, antiarch \\
\hline 138 & 139 & f.7548[offcuts] & ?Venezuelepis, Cd1 plate,osteolepid scale \\
\hline 139 & 139 & & antiarch PVL plate, left \\
\hline 140 & 139 & & antiarch ?PVL plate \\
\hline 141 & 139 & & antiarch $\mathrm{Cd} 1$ plate, osteolepid scales \\
\hline 142 & 139 & & antiarch pect.fin plates, osteolepid scales \\
\hline 143 & 139 & f.7549[scale] & Bothriolepis, PVL, MxL plates, round striated scale \\
\hline 144 & 139 & & Bothriolepis, AVL, MI2 plates \\
\hline 145 & 139 & & Bothriolepis, $\mathrm{Mm} 2$ plate \\
\hline 146 & 139 & f. $7550[2$ scales $]$ & Bothriolepis PVL plate; striated scales \\
\hline 147 & 139 & & antiarch, ?asterolepid $\mathrm{Cd} 1,2$ plates \\
\hline 148 & 139 & & Bothriolepis, PMD plate, \\
\hline 149 & 139 & & Bothriolepis, ?ADL plate \\
\hline 150 & 139 & & Bothriolepis, PMD, pect.fin bones \\
\hline 151 & 139 & & antiarch, pectoral fin bones \\
\hline 152 & 139 & & Bothriolepis, AMD, MxL, and other bones \\
\hline 153 & 139 & & Bothriolepis, Nu, AMD, ADL, pect.fin bones \\
\hline 154 & 139 & & Bothriolepis, MxL, left AVL, ?Venezuelepis Cd1 \\
\hline 155 & 139 & & antiarch bones, osteolepid scales \\
\hline 156 & 139 & f.7551[offcuts] & antiarch ADL, PVL, ?Venezuelepis pect.fin bones \\
\hline 157 & 139 & & antiarch, indeterminate bones \\
\hline 158 & 139 & f.7552[scale] & lungfish scale, Bothriolepis AMD, pect.fin bones \\
\hline 159 & 139 & f.7553[offcuts] & antiarch ADL, osteolepid ?cheek bone \\
\hline 160 & 139 & & antiarch ADL bone, right, incomplete \\
\hline 161 & 139 & f. 7554 [scale] f.7555[scale] & round osteichthyan scales \\
\hline 162 & 139 & & antiarch, indeterminate bones \\
\hline 163 & 139 & & Bothriolepis, MxL, PVL, AMD, Cv2; round scales \\
\hline 164 & 139 & & Bothriolepis, Cv2 plate (internal) \\
\hline 165 & 139 & & Bothriolepis, various bones; scales \\
\hline 166 & 139 & & osteichthyan scale (?) \\
\hline 167 & 139 & & Bothriolepis, AVL bone, right \\
\hline 168 & 139 & f. $7556[$ La plate] & Bothriolepis, La, AVL (?or Venezuelepis PDL); c/part already collected \\
\hline
\end{tabular}




\begin{tabular}{|c|c|c|c|}
\hline $\begin{array}{l}\text { MBLUZ } \\
\text { P-No. }\end{array}$ & Loc. No. & $\begin{array}{l}\text { MB. f. No. } \\
\text { [specimen] }\end{array}$ & Determination \\
\hline 169 & 139 & f. 7557 [scale] & scale, large, cosmoid \\
\hline 170 & 139 & f.7558[scale] f.7559[scale] & scale cosmoid (rough inner surface), antiarch bones \\
\hline 171 & 139 & & antiarch, coarsely ornamented bones \\
\hline 172 & 139 & & antiarch PVL bone, right \\
\hline 173 & 139 & f. 7560 [offcuts] & Bothriolepis, $\mathrm{Cv} 2$, other bones \\
\hline 174 & 139 & & ?Bothriolepis, $\mathrm{MxL}$, right, other bones \\
\hline 175 & 139 & & antiarch, indet. (?Venez) \\
\hline 176 & 139 & & antiarch, indet. \\
\hline 177 & 139 & f.7561[MV plate] & Bothriolepis, AVL, PVL, AMD, MV, pf bones \\
\hline 178 & 139 & & osteolepid scale, possible lower jaw \\
\hline 179 & 139 & f. $7562[\mathrm{MxL}$ plate] & Bothriolepis, MxL,other bones \\
\hline 180 & 139 & & Bothriolepis, AVL, right, \& other bones \\
\hline 181 & 139 & & Bothriolepis, various bones \\
\hline 182 & 139 & f.7563[HOLOTYPE] & Bothriolepis, articulated specimen, ventral view \\
\hline 183 & 139 & & antiarch various bones \\
\hline 184 & 139 & & Bothriolepis, AMD bone, incomplete \\
\hline 185 & 139 & & Bothriolepis, AVL, right, $\mathrm{Cd}, \&$ other bones \\
\hline 186 & 139 & & Bothriolepis, MI2 bone, round scale \\
\hline 187 & 139 & & Bothriolepis, Cv1 bone \\
\hline 188 & 139 & f. $7564[\mathrm{Nu}$ plate $]$ & Bothriolepis, Nu bone, large, with other bones \\
\hline 189 & 139 & & Bothriolepis, small pf bones \\
\hline 190 & 139 & & antiarch ?ADL bone \\
\hline 191 & 139 & & Bothriolepis, AVL, right, AMD, MxL, \& fin bones \\
\hline 192 & 139 & & Bothriolepis, La, right, \& Nu bones \\
\hline 193 & 139 & & antiarch, various bones \\
\hline 194 & 139 & & ?osteichthyan scale, round, large \\
\hline \multirow[t]{2}{*}{195} & 139 & f.7565[AMD, p, c/part] & Bothriolepis, Nu, AVL, left, AMDs, PVL etc. \\
\hline & 139 & f. $7566[$ PVL plate $]$ & \\
\hline 196 & 139 & & scale, large osteolepid \\
\hline 197 & 139 & f. $7567[\mathrm{Ml} 2$ plate $]$ & Bothriolepis M12; right elongate PVL(?Venezuelepis) \\
\hline 198 & 139 & & antiarch, various bones \\
\hline 199 & 139 & & Bothriolepis, Cv1 bone \\
\hline 200 & 139 & f. $7568[? P L$ plate $]$ & ?Venezuelepis, ?PL plate \\
\hline 201 & 139 & & Bothriolepis, $\mathrm{Nu}, \mathrm{PP}$, other bones \\
\hline 202 & 139 & & Bothriolepis, Cv2 plate, osteolepid scale \\
\hline 203 & 139 & & Bothriolepis, Cv1 and MxL, left \\
\hline 204 & 139 & & osteolepid scale or bone \\
\hline 205 & 139 & & indeterminate bone \\
\hline 206 & 139 & & indeterminate bone; ?placoderm, cf.P-200 \\
\hline 207 & 139 & & Scale (?), large, in matrix \\
\hline 208 & 139 & & Bothriolepis, AMD bones (2) \\
\hline 209 & 139 & & Bothriolepis, Fin bones \\
\hline 210 & 139 & & Bothriolepis, $\mathrm{Nu}$ bone \\
\hline 211 & 139 & & Bothriolepis, AMD bones (2), internal of $\mathrm{MxL}$ \\
\hline 212 & 139 & & Bothriolepis, AMD, incomplete \\
\hline 213 & 139 & & Bothriolepis, various bones \\
\hline 214 & 139 & & Bothriolepis, ADL, left, \& other bones \\
\hline 215 & 139 & & Bothriolepis, PVL, right, \& fin bones \\
\hline 216 & 139 & & antiarch bones, and a scale \\
\hline 217 & 139 & & Bothriolepis, PVL and $\mathrm{Cd} 2$ bones, osteolepid tooth? \\
\hline 218 & 139 & & Bothriolepis, PVL bone, left, in matrix \\
\hline 219 & 139 & & Bothriolepis, PVL, ADL, MxL, Nu, \& other bones \\
\hline 220 & 139 & & Bothriolepis, MxL, right, incomplete \\
\hline 221 & 139 & & Bothriolepis, AVL, right, \& other bones \\
\hline 222 & 139 & & Bothriolepis, AMD bones (2) \\
\hline 223 & 139 & & Bothriolepis, AVL, right, \& other bones \\
\hline 224 & 139 & f.7569[AMD plate] & Bothriolepis, AMD, MI2, Nu, \& other bones \\
\hline 225 & 139 & & Bothriolepis, PVL bone, left \\
\hline 226 & 139 & & osteolepid scale \\
\hline 227 & 139 & & possible osteichthyan/arthrodire bone \\
\hline 228 & 139 & f. $7570[\mathrm{p}, \mathrm{c} / \mathrm{part}]$ & Bothriolepis, AMD, left AVL [incompl.] \\
\hline 229 & 139 & f. $7571[$ SM plate] & Bothriolepis, SM, other bones \\
\hline 230 & 139 & f. $7572[\mathrm{M} 12$ plate $]$ & Bothriolepis, PVLs, left, right together; M12 \\
\hline 231 & 139 & & Bothriolepis, PVL (?) bone \\
\hline \multirow[t]{2}{*}{232} & 139 & f. $7573[?$ clavicle $]$ & Bothriolepis, PMD, MxL; ?clavicle on reverse. \\
\hline & 139 & f. $7574[\mathrm{PMD}, \mathrm{p}, \mathrm{c} / \mathrm{part}]$ & \\
\hline 233 & 139 & & indet. antiarch bones \\
\hline 234 & 139 & & indet. antiarch bones \\
\hline 235 & 139 & & indet. antiarch bones \\
\hline
\end{tabular}




\begin{tabular}{|c|c|c|c|}
\hline $\begin{array}{l}\text { MBLUZ } \\
\text { P-No. }\end{array}$ & Loc. No. & $\begin{array}{l}\text { MB. f. No. } \\
\text { [specimen] }\end{array}$ & Determination \\
\hline 236 & 139 & f.7575[MxL plate] & Bothriolepis, $\mathrm{MxL}$ bone, right \\
\hline 237 & 139 & & Bothriolepis, La, incomplete, and other bones \\
\hline 238 & 139 & & Bothriolepis, small bones \\
\hline 239 & 139 & & Bothriolepis, AMD, incomplete, \& other bones \\
\hline 240 & 139 & & Bothriolepis, PMD (?) bone \\
\hline 241 & 139 & & Bothriolepis, indet. Bone \\
\hline 242 & 139 & & Bothriolepis, AVL \& MxL (?) bones \\
\hline- & 118 & f.7630 & ?antarctilamnid spine impression \\
\hline 243 & 139 & f7632[offcuts] & Venezuelepis, Cd1 bone,part and c/part \\
\hline 244 & 139 & f.7633[AMD plate] & Bothriolepis, AMD bone \\
\hline 245 & 139 & f.7634[PMD p, c/part] & Bothriolepis, PMD \& other bones \\
\hline 246 & 139 & & Bothriolepis, $\mathrm{Nu} \& \mathrm{Cd}$ or $\mathrm{Cv} 1$ bones \\
\hline 247 & 139 & & Venezuelepis, AMD bone, part and c/part \\
\hline 248 & 139 & & Bothriolepis, Cv2 (?) bone \\
\hline 249 & 139 & & Bothriolepis, indet. bones \\
\hline 250 & 139 & & antiarch pect. fin bones \\
\hline 251 & 139 & & osteolepid tooth; antiarch bones \\
\hline 252 & 139 & & Bothriolepis, La, incomplete, and other bones \\
\hline 253 & 139 & & Bothriolepis, $\mathrm{Cv} 1$ bone, right \\
\hline 254 & 139 & & Bothriolepis, MxL bone impression, left \\
\hline 255 & 139 & & osteolepid scale, antiarch bones \\
\hline 256 & 139 & & Bothriolepis, MI2 \& PvL (?) bones, in matrix \\
\hline 257 & 139 & & osteolepid scale, ridged bone (distal pf segment?) \\
\hline 258 & 139 & & Bothriolepis, $\mathrm{ADL}$, bone, right, \\
\hline 259 & 139 & & Bothriolepis, various bones \\
\hline 260 & 139 & & Bothriolepis, AVL+pf, right PVL; ?Cd1 of Venezuelepis \\
\hline 261 & 139 & & Bothriolepis, AVL $+\mathrm{pf}$ \\
\hline 262 & 139 & & $\mathrm{Cd} 1$, ? Venezuelepis \\
\hline 263 & 139 & & antiarch bones \\
\hline 264 & 139 & & antiarch ADL \& other bones \\
\hline 265 & 139 & & Venezuelepis?, possible pf bone \\
\hline 266 & 139 & & Bothriolepis,left $\mathrm{MxL}$; round scales \\
\hline 267 & 139 & & indet. antiarch bones \\
\hline 268 & 139 & & indet. antiarch bones \\
\hline 269 & 139 & & Bothriolepis, AMD \& other bones \\
\hline 270 & 139 & & Venezuelepis, possible PDL (?) bone, left \\
\hline 271 & 139 & & indet. antiarch bones \\
\hline 272 & 139 & f.7635[scale, $p, c /$ part] & osteolepid, round scales; various antiarch bones \\
\hline 273 & 139 & & Bothriolepis, PMD bone \\
\hline 274 & 139 & f. $7636[\operatorname{PrM}$ plate $]$ & Bothriolepis, PrM \& other bones \\
\hline 275 & 139 & & Bothriolepis, ADL (?) and Nu bones \\
\hline 276 & 139 & & antiarch, indet.bones \\
\hline 277 & 139 & & antiarch PVL (?) bone \\
\hline 278 & 139 & & Bothriolepis, AMD, incomplete \\
\hline 279 & 139 & & Bothriolepis, small AMD, large osteolepid scale \\
\hline 280 & 139 & & osteolepid scale, other antiarch bones \\
\hline 281 & 139 & & antiarch bones/fragments indet. \\
\hline 282 & 139 & & antiarch bones/ fragments indet. \\
\hline 283 & 139 & & antiarch bones/ fragments indet. \\
\hline 284 & 139 & & Bothriolepis, pectoral fin bones \\
\hline 285 & 139 & & Bothriolepis, various bones \\
\hline 286 & 139 & & Bothriolepis, various bones \\
\hline 287 & 139 & & antiarch bones/ fragments, indet. \\
\hline 288 & 139 & & antiarch bones/ fragments, indet. \\
\hline 289 & 139 & & antiarch bones/ fragments, indet. \\
\hline 290 & 139 & & Bothriolepis, pectoral fin bones \\
\hline 291 & 139 & & Bothriolepis, bones, indet. \\
\hline 292 & 139 & & Bothriolepis, bones, indet. \\
\hline 293 & 139 & & Bothriolepis, bones, indet. \\
\hline 294 & 139 & & Bothriolepis, bones, indet. \\
\hline 295 & 139 & & Bothriolepis, bones, indet. \\
\hline 296 & 139 & & antiarch, bones, indet. \\
\hline 297 & 139 & & Bothriolepis, bones, indet. \\
\hline 298 & 139 & & ?antiarch bones, indet. \\
\hline 299 & 139 & & ?antiarch bones, indet. \\
\hline 300 & 139 & & ?antiarch bones, indet. \\
\hline 301 & 139 & & ?antiarch bones, indet. \\
\hline 302 & 139 & & ?antiarch bones, indet. \\
\hline 303 & 139 & & Bothriolepis, bones, indet. \\
\hline
\end{tabular}




\begin{tabular}{|c|c|c|c|}
\hline $\begin{array}{l}\text { MBLUZ } \\
\text { P-No. }\end{array}$ & Loc. No. & $\begin{array}{l}\text { MB. f. No. } \\
\text { [specimen] }\end{array}$ & Determination \\
\hline 304 & 139 & & Bothriolepis, bones, indet. \\
\hline 305 & 139 & & antiarch bones, indet. \\
\hline 306 & 139 & & Bothriolepis, bones, indet. \\
\hline 307 & 139 & & ?osteichthyan scale, \\
\hline 308 & 139 & & Bothriolepis, incomplete bones \\
\hline 309 & 139 & & Bothriolepis, $\mathrm{Nu}$ bone, incomplete \\
\hline 310 & 139 & f.7637[scale] & osteolepid scale \\
\hline 311 & 139 & & antiarch PL (?) bone \\
\hline 312 & 139 & & Bothriolepis, indet. bone \\
\hline 313 & 139 & & scale, round, incomplete \\
\hline 314 & 139 & & osteolepid scale, incomplete \\
\hline 315 & 139 & & osteolepid scale, incomplete \\
\hline 316 & 139 & & Bothriolepis, bone, incomplete \\
\hline 317 & 139 & & large osteolepid scale impression, \\
\hline 318 & 139 & & Bothriolepis, Nu bone, incomplete \\
\hline 319 & 139 & & osteolepid scale \\
\hline 320 & 139 & f.7638[PMD, PVL] & Bothriolepis PMD,PVL; osteolepid scale \\
\hline 321 & 139 & & Bothriolepis, various incomplete bones \\
\hline 322 & 139 & & Bothriolepis, various incomplete bones \\
\hline 323 & 139 & & Bothriolepis, PrM (?) bone \\
\hline 324 & 139 & & Bothriolepis, bone, incomplete \\
\hline 325 & 139 & & Bothriolepis, bone, incomplete \\
\hline 326 & 139 & & Bothriolepis, AMD bone \\
\hline 327 & 139 & & Bothriolepis, bone, incomplete \\
\hline 328 & 139 & & Bothriolepis, bone, incomplete \\
\hline 329 & 139 & & ?antiarch bone fragment \\
\hline 330 & 139 & & Bothriolepis, bone, incomplete \\
\hline 331 & 139 & & Bothriolepis, bone, incomplete \\
\hline 332 & 139 & & Bothriolepis, $\mathrm{Nu}$ bone, incomplete \\
\hline 333 & 139 & & antiarch fragment \\
\hline 334 & 139 & & Bothriolepis, various bones \\
\hline 335 & 139 & & Bothriolepis, various bones \\
\hline 336 & 139 & & osteolepid scale \\
\hline 337 & 139 & & osteoichthyan? scale, round \\
\hline 338 & 139 & & antiarch bone fragment \\
\hline 339 & 139 & & antiarch bone fragment \\
\hline 340 & 139 & & antiarch bone fragment \\
\hline 341 & 139 & & antiarch bone fragment \\
\hline 342 & 139 & & antiarch bone fragment \\
\hline 343 & 139 & & Bothriolepis?, bone fragment \\
\hline 344 & 139 & & antiarch bone fragment \\
\hline 345 & 139 & & antiarch bone fragment \\
\hline 346 & 139 & & osteolepid scale \\
\hline 347 & 139 & & antiarch bone fragment \\
\hline 348 & 139 & & antiarch bone fragment \\
\hline 349 & 139 & & antiarch bone fragment \\
\hline 350 & 139 & & antiarch bone fragment \\
\hline 351 & 139 & & osteolepid scales \\
\hline 352 & 139 & & ?osteolepid scales \\
\hline 354 & 139 & & osteolepid scale \\
\hline 355 & 139 & & Scale, heart-shaped or possibly round \\
\hline 356 & 139 & & Bothriolepis, fin bones, bone impressions \\
\hline 357 & 139 & & Bothriolepis, $\mathrm{Nu}$ bone \& bone impressions \\
\hline 358 & 139 & & antiarch bone fragments \\
\hline 359 & 139 & f. 7639 [striated scales] & antiarch bone fragments, striated scales \\
\hline 421 & 139 & & osteolepid ?bone fragment \\
\hline 902 & 118 & & Machaeracanthus, spine impressions \\
\hline 903 & 118 & & Machaeracanthus, spine impressions \\
\hline 904 & 118 & & shark (?antarctilamnid) spine impressions \\
\hline 1112 & 118 & & Machaeracanthus, spine impressions \\
\hline 1113 & 118 & & shark (?antarctilamnid) spine impressions \\
\hline 1114 & 118 & & Machaeracanthus, spine impressions \\
\hline 1115 & 118 & & Machaeracanthus, spine impressions \\
\hline 1116 & 118 & & shark (?antarctilamnid) spine impressions \\
\hline 1346 & 118 & & Machaeracanthus, spine impressions \\
\hline 1347 & 118 & & shark (?antarctilamnid) spine impressions \\
\hline 1348 & 118 & & ?acanthodian spine impression \\
\hline 1349 & 118 & & ?acanthodian spine impression \\
\hline 1387 & 150 & & ?placoderm (ptyctodontid?) plate \\
\hline
\end{tabular}




\begin{tabular}{llll}
\hline $\begin{array}{l}\text { MBLUZ } \\
\text { P-No. }\end{array}$ & Loc. No. & $\begin{array}{c}\text { MB. f. No. } \\
\text { [specimen] }\end{array}$ & Determination \\
\hline 1392 & 175 & & $\begin{array}{l}\text { Machaeracanthus, spine impressions } \\
\text { Machaeracanthus, spine impressions }\end{array}$ \\
1404 & 118 & 118 & Machaeracanthus, spine impressions \\
1406 & 118 & Machaeracanthus, spine impressions \\
1427 & 118 & shark (?antarctilamnid) spine impressions \\
1428 & 118 & shark (?antarctilamnid) spine impressions \\
1429 & 118 & shark (?antarctilamnid) spine impressions \\
1531 & 118 & Machaeracanthus, spine impressions \\
1532 & 118 & ?acanthodian spine impression, incomplete \\
1536 & 118 & ?acanthodian, 2 spine impressions, incomplete \\
1537 & 118 & unidentified ?antiarch plate \\
1538 & 118 & unidentified spines (2), small, incomplete \\
1539 & 118 & spine, wide base, indet. \\
1696 & 118 & ?acanthodian spine impressions (2) \\
1697 & 118 & ?acanthodian spine impressions (4), on a large block \\
1698 & 139 & Bothriolepis, ?head shield plates, incomplete \\
5001 & 139 & acanthodian scale, from acid residue \\
5002 & 139 & acanthodian scale, from acid residue \\
5003 & 139 & acanthodian scale, from acid residue \\
5004 & 139 & ?acanthodian scale, from acid residue
\end{tabular}

